\title{
Anorden
}

\section{Social Indicators in the Forest Sector in Northern Europe}

A Review focusing on Nature-based Recreation and Tourism
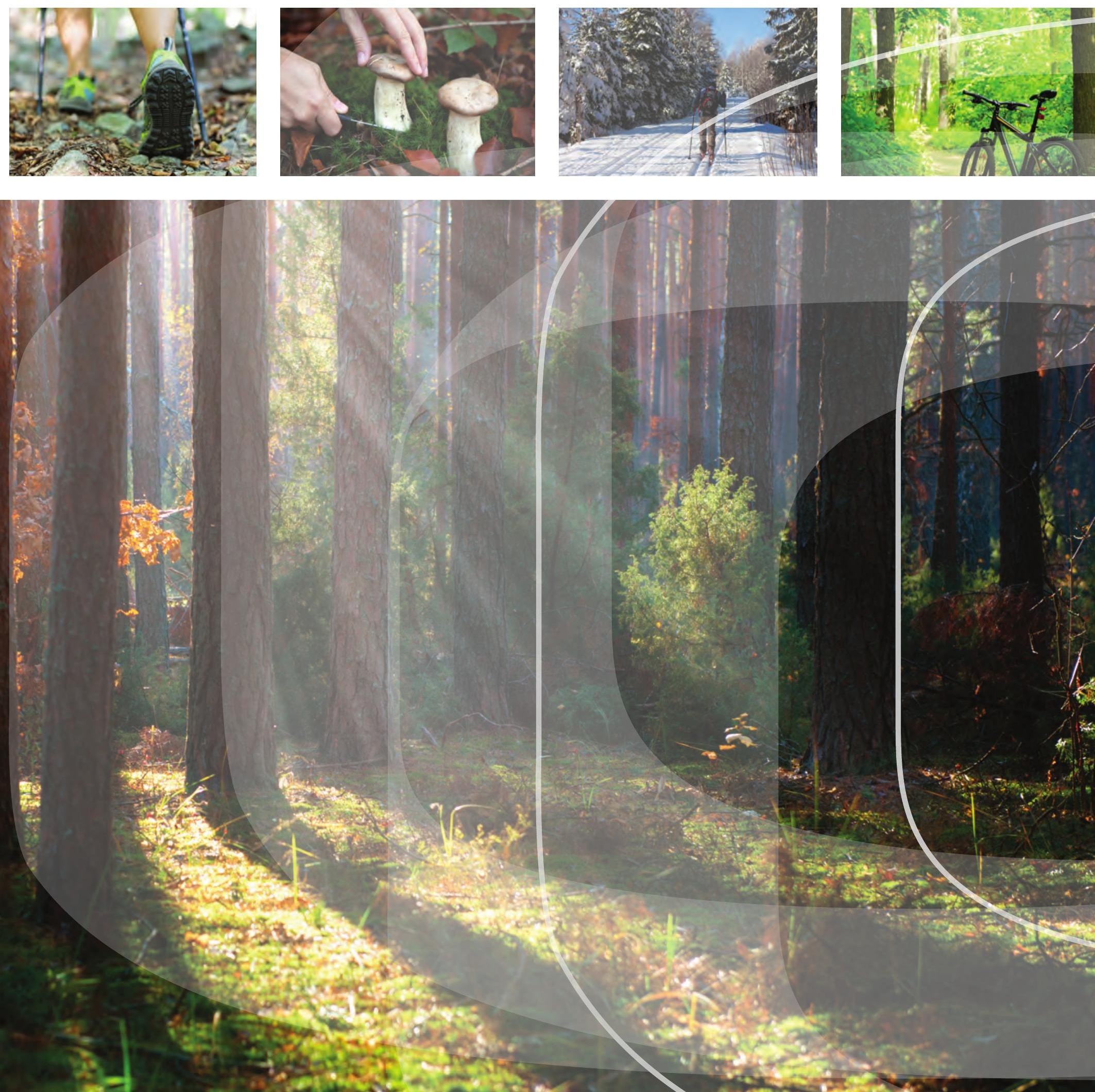

4 norden 



\title{
Social Indicators in the Forest Sector in Northern Europe
}

\author{
A Review focusing on Nature-based \\ Recreation and Tourism
}

Tuija Sievänen, David Edwards, Peter Fredman, Frank S. Jensen and Odd Inge Vistad (eds.)

TemaNord 2013:584 
Social Indicators in the Forest Sector in Northern Europe

A Review focusing on Nature-based Recreation and Tourism

Tuija Sievänen, David Edwards, Peter Fredman, Frank S. Jensen and Odd Inge Vistad (eds.)

ISBN 978-92-893-2658-2

http://dx.doi.org/10.6027/TN2013-584

TemaNord 2013:584

(C) Nordic Council of Ministers 2013

Layout: Hanne Lebech

Cover photo: ImageSelect

This publication has been published with financial support by the Nordic Council of Ministers. However, the contents of this publication do not necessarily reflect the views, policies or recommendations of the Nordic Council of Ministers.

www.norden.org/en/publications

\section{Nordic co-operation}

Nordic co-operation is one of the world's most extensive forms of regional collaboration, involving Denmark, Finland, Iceland, Norway, Sweden, and the Faroe Islands, Greenland, and Åland.

Nordic co-operation has firm traditions in politics, the economy, and culture. It plays an important role in European and international collaboration, and aims at creating a strong Nordic community in a strong Europe.

Nordic co-operation seeks to safeguard Nordic and regional interests and principles in the global community. Common Nordic values help the region solidify its position as one of the world's most innovative and competitive.

\section{Nordic Council of Ministers}

Ved Stranden 18

DK-1061 Copenhagen K

Phone (+45) 33960200

\section{www.norden.org}




\section{Content}

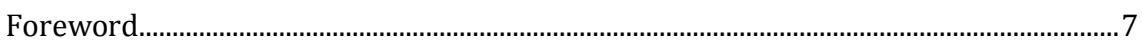

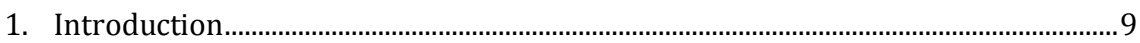

2. Review and evaluation of existing international nature-based recreation and tourism indicators and related issues................................................................... 15

2.1 Forest related social indicators at European level......................................... 15

2.2 Forest related social indicators at International level ................................... 20

2.3 Assessments of ecosystem services ................................................................. 22

2.4 Social indicators related to other sectors: health, wellbeing and tourism

3. Overview of nature-based recreation policies and indicators in North

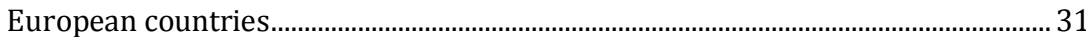

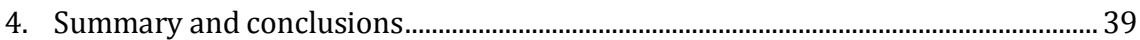

4.1 Indicators and monitoring related to nature-based recreation and

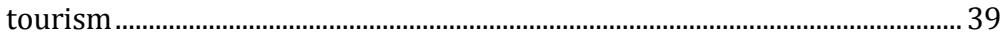

$4.2 \quad$ FOREST EUROPE indicators .......................................................................... 41

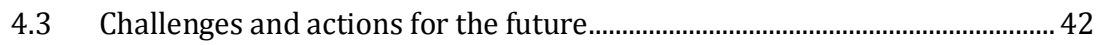

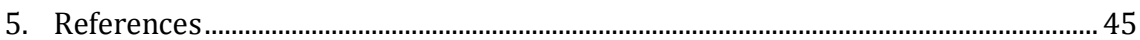

6. Appendix 1. Social indicators and monitoring in North European

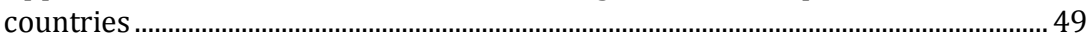

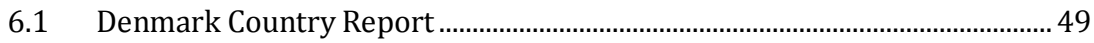

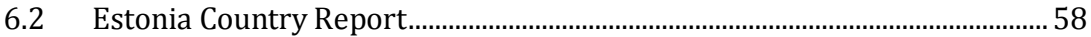

6.3 Finland Country Report............................................................................................ 67

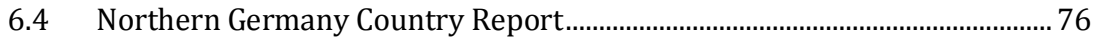

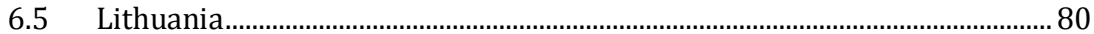

6.6 Norway Country Report..................................................................................... 81

6.7 North Western Russia Country Report........................................................... 94

6.8 Scotland Country Report................................................................................. 100

6.9 Sweden Country Report....................................................................................112

7. Appendix 2. FOREST EUROPE Indicator 6.10: "Accessibility for

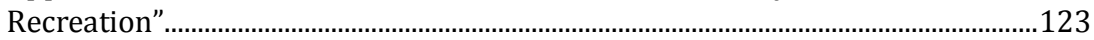

7.1 Annex 1: Primary sources for data on "intensity of use" ..............................124 



\section{Foreword}

This report provides a review of the state of the art of social indicators in forestry, particularly concerning nature-based recreation and tourism in North European countries. The work was carried out by a project group financed by SNS and EFINORD in 2012-2013. The member countries or regions were Denmark, Estonia, Finland, Northern Germany, Lithuania, Northwest Russia, Norway, Scotland and Sweden. The North-European networking project invited scientists and other experts to exchange ideas about social indicators for forestry. The common interest was to discuss how to develop social indicators, and monitor changes to social benefits, particularly recreation and tourism, in forestry and forest use. The expert group identified a need to develop social indicators, which should be effective, focused, and useful for many purposes in the forest sector but also in other sectors of natural resources in all European countries. It is timely to enhance standardization and harmonization of social indicators for monitoring and management of sustainable forestry and forest use, and for sustainable nature-based recreation and tourism. In all countries, there is a challenge to develop monitoring systems to produce inventory data for statistics that are required in a way that provides social indicators that are comparable across Europe.

Forest related social values such as recreation values are growing in importance in North European countries, and it is time to strengthen the recognition of social issues in forestry and forest use in a comparable way to the increased importance attached to ecological values during the last decades. Our urbanized societies need social services from forests and other nature areas. The key ecosystem service is the recreation environment, which provides benefits to human health and wellbeing. In addition, increasing possibilities to enhance commercial recreational use of forests has been recognized, particularly among private forest owners, who have many opportunities for new types of forest-related entrepreneurship.

This report provides expert-compiled background information for the further development of recreation indicators. The experts participating in this project report the state of the art in their country reports, and the project group has summarized and evaluated the results together.

\section{Editors}





\section{Introduction}

Tuija Sievänen, David Edwards, Peter Fredman, Frank S. Jensen \& Odd Inge Vistad

Sustainable development is now established as a long-term goal for most natural resources related policies. Within the forestry sector, sustainability has been a core principle since the early days of scientific enquiry, although its definition has evolved from a narrow focus on sustained yield to a broader understanding of the diverse benefits forests provide to society. At the first Ministerial Conference on the Protection of Forests in Europe (MCPFE, now branded as "FOREST EUROPE", which is used in this report), held in Helsinki in 1993, sustainable forest management was defined as "the stewardship and use of forests and forest lands in a way, and at a rate, that maintains their biodiversity, productivity, regeneration capacity, vitality and their potential to fulfil, now and in the future, relevant ecological, economic and social functions, at local, national, and global levels, and that does not cause damage to other ecosystems" (Resolution H1... 1993). The FOREST EUROPE process involves 45 European countries, and it has a counterpart in the Montréal Process in which countries such as United States, Canada, Australia, and New Zealand are involved (The Montréal Process 2013). The need to establish a global policy for sustainable use and management of forest resources is expressed also by the United Nations Forum on Forests (UNFF 2013).

The sustainability concept itself includes the idea that resources and their use need to be in balance so that the future of the resources and their use is not threatened, and future generations have the opportunity to use the resources in a similar way to that of present generations. The state of the balance between supply and demand should be known or possible to define, and, when agreed, development and changes over time should be monitored. When monitoring is required, there is a need for efficient measures, which describe the state of sustainability. Such measures are typically considered as indicators, and their description should be relevant to the phenomena in question and represent a valid way to measure change. 
Social sustainability is based upon the idea that human beings are at the centre of concerns for sustainable development. It means that people are entitled to a healthy and productive life in harmony with nature (Rio Declaration... 1992). Social sustainability also relates to social equity, and the idea of development for all, equality of opportunity and freedom of choice regardless of economic status, gender, or religious or ethnic group (Wiman 1994), i.e. that populations and cultures should have the opportunity to derive equal benefits from natural resources. This includes also the possibility of using natural resources for recreation and nature-based tourism. Sustainable recreational use of forests and other natural resources clearly involves all three dimension of sustainability. Yet another important aspect in the context of forestry is how the benefits from outdoor recreation and nature-based tourism compare with other uses such as commercial timber production in rural areas, or industrial or housing development in urban areas as well as nature conservation goals. The issue of equality between generations, present and future, needs to be considered as well as equality within generations, for example between local recreationists and tourists, or different types of recreationist (e.g. motorised versus non-motorised), or different social groups, or urban and rural populations.

The social values of forests, such as those associated with recreation, are growing in importance in North European countries. It is therefore important to strengthen the role of these issues in forestry and forest management in a comparable way to the increased importance given to ecological values over recent decades e.g. within the ecosystem services concept. Our urbanized societies increasingly need social services from forests and other nature areas, and a key cultural ecosystem service is the recreation environment, which provides benefits to human health and wellbeing (Nilsson et al. 2011).

In North European countries, outdoor recreation and particularly visits to forest are a very common leisure activity. In Denmark, Sweden, Norway and Finland, national outdoor recreation surveys show that 76 to $91 \%$ of the adult population pay visits to forest annually, and even more participate in outdoor recreation in nature areas in general. The frequency of forest visits varies greatly even between Nordic countries (between about 38 to 120 times per year per person) (Sievänen et al. 2009). Only a few countries have systematic monitoring of the recreational use of all forests. Some countries include all nature areas as recreation environment in their surveys. 
In addition, increasing possibilities to enhance commercial recreational use of forests has been recognized among both private landowners (e.g. the Farmers Association and the state owned forest company Sveaskog in Sweden) and tourism organizations (e.g. Swedish ecotourism Society). Tourism is an increasingly important economic activity in many countries around the world. The World Tourism Organization (WTO) estimates that international tourist arrivals (i.e. overnight visitors) grew by $4.6 \%$ in 2011 to 983 million worldwide (UNWTO 2012). Nature is a key factor attracting tourism in Northern Europe, and nature-based tourism is one of the most rapidly expanding sectors within the tourism industry (Bell et al. 2008). This increasing demand has created opportunities for nature-based tourism to develop as an economic development tool in regions rich in natural amenities, such as the forested regions of Northern Europe (Fredman and Tyrväinen 2010).

In several North European countries efforts have been made to develop indicators for recreation and cultural values (Kajala et al. 2007). In Finland, a report was prepared recently that provides recommendations for social indicators for monitoring of the National Forest Program in 2010 (Sievänen 2010). In Denmark a report on a strategy and manual for collection of outdoor recreation statistics were published in 2008 (Jensen et al. 2008). In Sweden social indicators for the sustainable management of landscape have been developed by the National Board of Housing, Building and Planning (Landskapets upplevelsevärden... 2007) and the National Board of Forestry has initiated a nation-wide inventory of forests with high social values (Skogsstyrelsen 2011). In northern UK, researchers have contributed to a framework of social indicators for monitoring the Scottish Forestry Strategy (Edwards et al. 2009). In this report, nine North European countries present a brief overview of social goals and indicators, which are related to the recreational use of forests and other natural resources.

Social indicators are an important instrument to support the policy of sustainable forest management policies. In the documentation of FOREST EUROPE, some social indicators for monitoring of sustainable forest management (SFM) are presented. The social indicators of SFM are reported in the State of Europe's Forests reports (State of Europe's... 2011) at country and regional level. Many North European countries are involved in the FOREST EUROPE process, and thus they should report indicators of recreational use. However, most countries seem to have difficulties in reporting (see later in this report). One objective of this report is to react to the need for evaluation of the current FOREST EUROPE indicators in the North European context. In this report, the status 
of recreation monitoring is also reviewed in order to understand the reasons behind the difficulties in reporting FOREST EUROPE indicators. Furthermore, the assumption is that there is a need to further develop social indicators for forest sector but also for other, related sectors beyond forests and forestry such as land use management in general, urban development, protected areas, tourism, energy production, transportation systems, agriculture, and water resources management. Given more recent landscape oriented approaches to natural resource management (Jones and Stenseke 2010) we also emphasize the importance of indicator integration across different sectors.

Monitoring sustainable development of natural resources demands good indicators. Current social changes (e.g. urbanisation and globalisation) and increased recognition of the nature-based recreational benefits to society (e.g. improved public health and regional development) call for indicators to better monitor future development. The shortage of suitable social indicators and monitoring systems highlights the need for further development, and a process initiated to create comparable and harmonized indicators across different countries. The major problem of social indicators in most countries is that there is a serious shortage of reliable data to provide quantitative figures. According to COST E33 reporting, most European countries lack efficient monitoring systems to offer estimates of indicators across time and regions (Sievänen et al. 2008). Recreation monitoring is taking place in several North European countries, but less so in other parts of Europe. Also in the North monitoring methods and outputs vary greatly between countries. In some countries, there are efforts to include (some) recreation measurements into forest inventory systems (e.g. Danish National Forest Inventory, Jensen et al. 2008) while in other countries measures of recreation are split between different sectors (e.g. Sweden). Many countries also implement national outdoor recreation demand and especially national recreation practise inventories (Denmark, Finland, Norway, Sweden), but these are not applied consistently across the region and the findings usually have very limited value when it comes to judging or improving local or regional forestry or forest use and management.

There is a clear need for further development of social indicators for monitoring and management of sustainable forestry and forest use, and for sustainable nature-based recreation and tourism. It is timely to evaluate possible social and particularly recreation indicators, and to look for possibilities to harmonize and standardize methodologies, and to choose some key variables to be measured in order to get comparable statistics and indicators in North European countries. The aim of this report is to 
describe the experiences of monitoring social indicators in Northern Europe countries. The report gathers background information from nine North European countries for further development of social indicators and monitoring of changes to social issues, particularly recreation and tourism, in forestry and forest use. This has been a challenge since countries vary with respect to the amount of work that has been done and also their level of interest and willingness to participate in a process of this type.

The report brings together contributions from a group of scientists and practitioners from nine countries - Denmark, Estonia, Finland, Lithuania, Norway, North Germany, North Western Russia, Scotland and Sweden - and draws from their expert knowledge as well as literature available from their respective countries and professional contacts. This work was done in a project "Social indicators in Forestry" financed by SNS-EFINORD in 20122013. Because of the networking nature of the project, there are limitations and knowledge gaps. Limited resources were available to conduct reviews in each country or to involve all those with relevant experience.

The scope of the project and definitions used for terms such as indicators, recreation, forests, etc., were not possible to resolve precisely. To some extent they will remain questions for further investigation during subsequent research projects. In particular, the project focused on forests, but acknowledged that in some countries monitoring of recreation does not always distinguish between forest and other nature area types, or between production areas, "ordinary" nature areas and protected areas, and these categories together might better define the scope of the project. Meanwhile, a forest can be defined differently across Europe, for example in terms of its size, canopy cover and location. Similarly, there are ambiguities around the definition of the terms "recreation" and "tourism". This is defined differently across the region in terms of the time spent and distance travelled, and may or may not include activities such as hunting and gathering. 



\section{Review and evaluation of existing international nature- based recreation and tourism indicators and related issues}

David Edwards, Peter Fredman, Frank S. Jensen, Liisa Kajala, Tuija Sievänen \& Odd Inge Vistad

This section considers the relevant existing indicators at EU and international level, with a focus on the FOREST EUROPE pan-European process for monitoring sustainable forest management. We discuss related issues, including the increased use of the Ecosystem Services framework to assess environmental change, and indicators relating to other sectors including health and wellbeing and tourism.

\subsection{Forest related social indicators at European level}

Monitoring of sustainable forest management (SFM) at European level has an established system initiated by the Ministerial Conference on the Protection of Forests in Europe (FOREST EUROPE) in Strasbourg 1990, now branded as Forest Europe. The FOREST EUROPE process has the commitment of 45 states in the European region and neighbouring countries. Thirty-five quantitative indicators of SFM are compiled at intervals of 4 years, and then reported in the State of Europe's Forests reports (State of Europe's... 2011) at country and regional level.

Three indicators relate to recreation and tourism, most notably Indicator 6.10: Accessibility for recreation and intensity of use, but also 6.11: Cultural and spiritual values and 3.4: Value of marketed services on forest and other wooded land. Their full definitions and issues relating to how they are reported are given below. 


\subsubsection{FOREST EUROPE Indicator 3.4. Services}

The 3.4 indicator refers to "Value of marketed services on forest and other wooded land." Marketed services have gained increasing attention in recent years. Marketed services (in the FOREST EUROPE framework) should be forest-dependent or mainly forest-related, but are not necessarily marketed by forest owners (e.g. eco-tourism). Four categories of services can be distinguished, and of these the social services are of most relevance to the scope of this report:

- Marketed ecological (protective) services include those related to FOREST EUROPE Indicators for soil, water and other environmental functions as well as infrastructure and managed natural resources on a voluntary contractual basis with compensation or other payments from private or public bodies.

- Marketed biospheric (environmental) services include services related to FOREST EUROPE Indicators for (in situ or ex situ gene) conservation of genetic resources, and protected forest area, e.g. nature protection on a voluntary contractual basis with compensation or other payments from private or public bodies. This includes NATURA 2000 sites. This category also includes carbon sequestration-related afforestation projects in the context of the Kyoto Protocol.

- Marketed social (recreational) services include hunting or fishing licences, renting of huts and houses, as well as forest-based leisure, sports and outdoor activities and educational services that are not free of charge to the consumers. Recreational services not exchanged via market transactions are not reported (but are covered, to some extent, by Indicator 6.10).

- Other marketed services include payments to woodland owners for licences that regulate land use for organic matter extraction, telecommunication masts, wind farms and electricity distribution, among others.

At the last round of data gathering (State of Europe's... 2011), the value of marketed services was only reported by 16 countries. A number of countries reported difficulties in identifying and quantifying marketed services value (most services are non-market services). The value or income is seldom known or registered, or covers only part of the forest sector (e.g. private versus public ownership). Probably the best documented marketed services are hunting and fishing licences. About half of the reporting countries provided data on hunting licences, which are one of the most important traditional services. The total amount of value for 
marketed services, considering the relatively low number of responding countries, is almost EUR 818 million. Social (recreational) services represent by far the most important value, with a share of $50 \%$ of the reported total marketed services value.

From the enquiry for the 2011 report, it is obvious that even though data on marketed services are very limited in FOREST EUROPE countries, they represent a substantial income for the forest sector. Looking at the reported data - and the difficulties in this respect - one should be cautious regarding the validity of the given value of the marketed services at a country-level and even more at a European-level. Looking forward, the implementation of NATURA 2000 as well as the development in climate mitigation policies suggest that we will see increasing use of market based instruments to support the provision of these ecosystem services.

\subsubsection{FOREST EUROPE Indicator 6.10: Accessibility for recreation and intensity of use}

The 6.10 indicator refers to "Area of forest and other wooded land where public has a right of access for recreational purposes and indication of intensity of use." Of the existing indicators used at a panEuropean level, FOREST EUROPE Indicator 6.10 is of most relevance to the scope of SOSIN. The indicator represents two types of information. Firstly, accessibility for recreation is perhaps the easiest measure to provide at country level across Europe, but is limited in value because it uses a simple legal definition of accessibility, which in most countries applies to nearly all forest and other wooded land. It does not measure physical accessibility, for example distances from forest to population centres of a given minimum size. The quantitative measure of these indicators is described by a percentage of forested land. Nearly all FOREST EUROPE signatory states provide data on this aspect of the indicator. However, of greater value for monitoring SFM is "intensity of use". Work to understand how data is collected could inform proposals for common definitions and methods that could then be promoted across Europe to enhance the quality of this part of the indicator. This is perhaps the priority area for the development of social indicators for forestry at European level. A brief analysis of the reporting of "intensity of use" in the last two rounds of the State of Europe's Forests (SOEF) reports is given here (see also Appendix 2.).

In the SOEF 2011 report, 15 countries provided estimates for "intensity of use" for the reporting year 2005. While this still represents only around one-third of the total number of countries, it is an improvement 
on the SOEF 2007 report where only 10 countries provided estimates. Of these 15 countries, ten provided data for numbers of visits to all forests in their respective countries: Czech Republic, Denmark, France, Germany, Ireland, Lithuania, Netherlands, Norway, Switzerland and UK. Five countries (Croatia, Cyprus, Estonia, Russian Federation and Ukraine) provided estimates which only cover a small proportion of the forest area, typically National Parks.

For nearly all countries that reported data, several assumptions were not made explicit in the SOEF reporting. The quality of the data from the next reporting round could be improved if the need to specify this information is made clearer in the reporting form: a) the area of forest and other wooded land covered by the estimate, $b$ ) the definition of visits that was used, and c) the primary data sources. Assuming countries provide this information, when this indicator is written up in SOEF 2015, it would also be worth highlighting which estimates for "intensity of use" referred to subsets of total forest cover, and quoting this area in the text. Otherwise, the variations in intensity of use between countries are likely to be misinterpreted.

The SOEF reports and individual country reports do not give enough information on methods used to estimate number of visits as a basis for recommending improved approaches to be used across Europe. For this reason, it would be worth examining the primary sources. This would also allow existing figures to be checked, and some of the assumptions to be clarified.

Appendix 2 gives a list of the primary sources used in the SOEF reporting and in other key secondary sources: COST E33, UNECE/FAO (2005), and SOSIN. Appendix 2 also collates and analyses the original data and comments from SOEF 2007 and 2011.

\subsubsection{FOREST EUROPE Indicator 6.11: Cultural and spiritual values}

This indicator is defined as "Number of sites within forest and other wooded land designated as having cultural or spiritual values." It is a simple and arguably narrow measure of the rich diversity of cultural and spiritual values associated with forests, but it is important to ensure this type of benefit is included, albeit in a partial way. The categories for this indicator were restructured and given clearer definitions for the State of Europe's Forests 2011 reporting round. The categories used were: 1) cultural heritage, 2) forested landscapes, 3) trees with cultural and spiritual values, and 4) other sites with cultural and spiritual values. The 
categories "archaeological" and "historical" were used in the SOEF 2007 report, but were brought together for SOEF 2011 under the single term "cultural heritage", because the distinction was not possible to define clearly. A further refinement was the recognition that cultural heritage sites can be either "of the forest", and hence historically associated with its management, or "in the forest", with no significant historical connection to the surrounding forest. This distinction was made in the reporting form, allowing countries with sufficient data to record the number of cultural heritage sites which were associated with historic forest management. In the SOEF 2011 report, 10 countries were able to provide this data. Overall, in SOEF 2011, 29 countries were able to provide data on at least one site, an improvement on SOEF 2007 where 22 countries provided data. This may reflect a growing recognition of the importance of cultural and spiritual values of forests across Europe.

\subsubsection{Conclusions regarding social FOREST EUROPE indicators}

It has been recognised by experts contributing to the State of Europe's Forests reports that the indicators of SFM do not capture the full range of social and cultural benefits of forests. Also, some of the social indicators chosen in the FOREST EUROPE process are very difficult to monitor. Problems recognized for some of the current social indicators, particularly those for nature-based recreation and tourism are:

- the indicators are not effective at offering reliable information of ongoing changes; the indicators are not describing the "right thing", or not effective at capturing the key values.

- there are no reliable measurements to offer for reporting, and few countries can provide time series for national or regional level information, which is needed to describe the status of the indicators.

- there are no clear standards for the information with which to describe the indicator, and thus information gathered may not be comparable between countries.

- the current FOREST EUROPE indicators are difficult to measure across all countries, and the information provided may not be comparable after all.

Based on these observations, it is obvious that there is a need to improve monitoring systems for social values of sustainable forest management, particularly for recreation and tourism at national and regional level, 
which could be applied across all (North) European countries. The first step is to assess the possibilities for standardizing and harmonizing social indicators, which could provide comparable figures across countries and regions. The core task for further development with the next project of social indicators in future is to assess what kind of social, especially recreation indicators are needed and are possible to implement, and what kind of quantitative data (numbers) can be collected on a continuous basis in different countries. Second, there is need for recommendations for improved monitoring systems to measure suggested indicators which should be reasonable in terms of cost. In all countries, there is a challenge to develop monitoring systems to produce inventory data for statistics that are required in providing comparable indicators across Europe.

\subsection{Forest related social indicators at International level}

At an international level, a number of monitoring systems have been established which relate to forestry and the environment. In 2006 the United Nations Commission on Sustainable Development agreed a set of 96 indicators of sustainable development, including 50 core indicators. Guidelines and methodology sheets are available as a reference for countries to develop national indicators of sustainable development. The core indicators include the proportion of land area covered by forests; the other indicators include per cent of forest trees damaged by defoliation and area of forest under sustainable forest management. However, as might be expected at this strategic level, there are no indicators for forest or nature based recreation or tourism. See: http://sustainabledevelopment.un.org/ index.php?menu=200 (Indicators.... 2013).

With regards to the forestry sector at global level, the Global Forest Resources Assessment (FRA) is compiled every five years. It was last published by FAO in 2010. Again there were no indicators relating directly to recreation and tourism. See: http://www.fao.org/forestry/fra/fra2010/ en/ (Global forest... 2010). The Collaborative Partnership on Forests established a portal in 2006 hosted by FAO on streamlining forest-related reporting. This includes links to several global processes. See: http://www.cpfweb.org/73035/en/ (Streamlining forest-related... 2013).

The Montréal process is very similar to the European MPCFE process, and covers Argentina, Australia, Canada, Chile, China, Japan, Korea, Mexico, New Zealand, Russian Federation, United States of America, and Uruguay (The Montréal Process 2013). The Montréal Process Working 
Group was formed in 1994 as a response to the pressing need for sustainable forest management. One of the main tasks was to develop and implement internationally agreed-upon criteria and indicators for the conservation and sustainable management of temperate and boreal forests. Criterion 6.4 concerns recreation and tourism (Criteria and Indicators... 2009): The rationale for it is formulated as follows: Forests have long been used as a place for recreation and other leisure activities. The location and accessibility of forests and the availability of recreation facilities are important to forest-based recreation and tourism. Levels of use are an indication of the extent to which forests are valued by society for these uses. This criterion is comparable to FOREST EUROPE Indicator 6.10.

The indicators are:

- 6.4.a Area and percent of forests available and/or managed for public recreation and tourism. Rationale: This indicator provides information on the area and extent of forests available and/or managed for recreation and tourism activities. The availability and management of forests for these activities is seen as a reflection of society's recognition of the value of forests for recreation and tourism.

- 6.4.b Number, type, and geographic distribution of visits attributed to recreation and tourism and related to facilities available. Rationale: This indicator provides a measure of the level and type of recreation and tourism use in forests. The number and geographic distribution of visits and the facilities available reflect the extent to which people participate in forest-based leisure activities and the importance of forests for recreation and tourism.

The other criterion related to recreation and tourism is 6.5 Cultural, social and spiritual needs and values. It is comparable to FOREST EUROPE Indicator 6.11. The rationale is People and communities, in both rural and urban areas, have a variety of cultural, social, and spiritual connections to forests based on traditions, experiences, beliefs, and other factors. Among them, the spiritual and cultural connections of indigenous people to forests often form part of their identity and livelihood. These values may be deeply held and influence people's attitudes and perspectives towards forests and how they are managed. These indicators provide information on the extent to which cultural, social, and spiritual needs and values exist and are recognized by society.

The indicators are: 
- 6.5.a "Area and percent of forests managed primarily to protect the range of cultural, social and spiritual needs and values", to which the rationale is "this indicator measures the extent of forests managed primarily for their cultural, social and spiritual values to people and communities, including indigenous communities and others with strong ties to forests. The protection of forests to meet such needs and values is a reflection of the extent to which they are recognized by society."

- 6.5.b "The importance of forests to people," and the rationale is "this indicator provides information on the range of values that communities and individuals hold for forests. These values shape the way people view forests, including their behaviors and attitudes to all aspects of forest management."

\subsection{Assessments of ecosystem services}

A number of international initiatives have sought to quantify and/or provide economic values for the ecosystem services attached to different habitat types including forests, in particular the Millennium Ecosystem Assessment (MA), and The Economics of Ecosystems and Biodiversity (TEEB) initiative. In many ways, the use of an Ecosystem Services framework in these initiatives builds upon existing Criteria and Indicator frameworks, which seek to take stock of the full range of environmental, social and economic benefits associated with natural resources. Therefore it is relevant to consider the various categories of goods and services, in particular the "cultural ecosystem services", which are used by these initiatives and their counterparts in some countries at national level, for example the UK National Ecosystem Assessment (2013).

\subsubsection{Millennium Ecosystem Assessment}

The Millennium Ecosystem Assessment (MA) assessed the consequences of ecosystem change for human well-being. From 2001 to 2005, the MA involved the work of more than 1,360 experts worldwide. Their findings are seen to provide a state-of-the-art scientific appraisal of the condition and trends in the world's ecosystems and the services they provide, as well as the scientific basis for action to conserve and use them sustainably. See: http://www.maweb.org/en/index.aspx

Ecosystem services are defined by the MA as the benefits people obtain from ecosystems. These include provisioning, regulating, and cul- 
tural services that directly affect people and supporting services needed to maintain the other services. (See: Chapter 2: Ecosystems and their services. In: "Ecosystems and human wellbeing: a framework for assessment" http://www.maweb.org/en/Framework.aspx.)

Cultural Services are defined by the MA as the nonmaterial benefits people obtain from ecosystems through spiritual enrichment, cognitive development, reflection, recreation, and aesthetic experiences, including:

- Cultural diversity. The diversity of ecosystems is one factor influencing the diversity of cultures.

- Spiritual and religious values. Many religions attach spiritual and religious values to ecosystems or their components.

- Knowledge systems (traditional and formal). Ecosystems influence the types of knowledge systems developed by different cultures.

- Educational values. Ecosystems and their components and processes provide the basis for both formal and informal education in many societies.

- Inspiration. Ecosystems provide a rich source of inspiration for art, folklore, national symbols, architecture, and advertising.

- Aesthetic values. Many people find beauty or aesthetic value in various aspects of ecosystems, as reflected in the support for parks, "scenic drives," and the selection of housing locations.

- Social relations. Ecosystems influence the types of social relations that are established in particular cultures. Fishing societies, for example, differ in many respects in their social relations from nomadic herding or agricultural societies.

- Sense of place. Many people value the "sense of place" that is associated with recognized features of their environment, including aspects of the ecosystem.

- Cultural heritage values. Many societies place high value on the maintenance of either historically important landscapes ("cultural landscapes") or culturally significant species.

- Recreation and ecotourism. People often choose where to spend their leisure time based in part on the characteristics of the natural or cultivated landscapes in a particular area.

This comprehensive list is informative because it highlights the wide range of social values associated with the natural environment, and underlines the challenges presented by attempts to define and express them in ways that could be measured through the use of quantitative indicators. 


\subsubsection{Economics of Ecosystems and Biodiversity (TEEB)}

TEEB was a major international initiative that drew attention to the global economic benefits of biodiversity, to highlight the growing costs of biodiversity loss and ecosystem degradation, and enable practical actions moving forward. TEEB used a tiered approach that involved three steps: recognising, demonstrating and capturing value:

- Step 1: For each decision identify and assess the full range of ecosystem services affected and the implications for different groups in society.

- Step 2: Estimate and demonstrate the value of ecosystem services, using appropriate methods.

- Step 3: Capture the value of ecosystem services and seek solutions to overcome their undervaluation, using economically informed policy instruments.

Practical guidance and illustrations of these steps are provided in the reports, and are supported by a collection of case studies from the local and regional level (so-called "TEEB cases"), which are available online. See: http://www.teebweb.org/

The recent TEEB report of Nordic countries also demonstrates well the importance of nature-based recreation and tourism as one of the cultural ecosystem services. The report includes examples of studies of economic value or assessment of economic impacts of recreation and nature tourism (see: http://www.ieep.eu/work-areas/biodiversity/financing-biodiversity/ 2013/01/socio-economic-socio-economic-importance-of-ecosystemservices-in-the-nordic-countries-synthesis).

\subsubsection{The Common International Classification of Ecosystem Services (CICES)}

The Common International Classification of Ecosystem Services (CICES) is developed from the work on environmental accounting undertaken by the European Environment Agency (EEA). It supports the EEA contribution to the revision of the System of Environmental-Economic Accounting (SEEA) which is currently being led by the United Nations Statistical Division (UNSD). The idea of a common international classification is an important one, because it was recognised that if ecosystem accounting methods were to be developed and comparisons made, then some standardisation in the way we describe ecosystem services was needed. Standardisation was seen as especially important where the link to eco- 
nomic accounting has to be made. CICES took as its starting point the typology of ecosystem services suggested in the Millennium Ecosystem Assessment (MA, 2005), Nature-based recreation is classified under section "Cultural", in division "Physical and intellectual Interactions", and class "Physical and experiential interactions" (table 1). CICES offers one approach to development of social indicators.

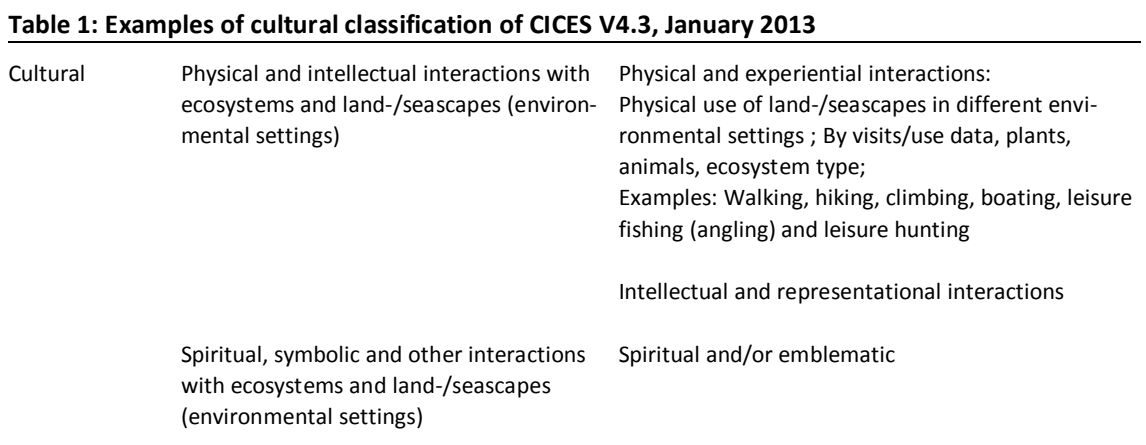

Source: http://cices.eu/29.8.2013; Haines-Young, R. \& Potschin, M. 2013.

\subsection{Social indicators related to other sectors: health, wellbeing and tourism}

\subsubsection{Health, wellbeing and social affairs}

Societies are increasingly recognizing the importance of measuring health and well-being of their citizens, in addition to measuring economic impacts (see e.g. Hoffrén et al. 2010, Budruk and Philips 2011). GDP (Gross Domestic Product) is not considered to be a sufficient measure of societies' overall performance. Therefore, efforts have been made to develop indicators that include also other dimensions of human wellbeing (Hoffrén et al. 2010 and Appendix 1), either to be integrated with GDP or considered separately. These society level measures are primarily developed for the purpose of international comparisons and are not very helpful for monitoring development at a national level. They also typically do not include access to nature as a dimension.

A fair amount of research exits on the impacts of nature on human health and well-being. Also, there is a growing world-wide recognition of the positive impacts of nature on human health (Healthy Parks... 2013) and an increasing number of land management agencies and other actors run programs to activate people to engage more with nature (e.g. in UK, Norway and Sweden). 
However, national indexes to measure the impacts of nature on health are almost non-existent. Some recent efforts to measure health and well-being impacts include a European tool designed to help conduct an economic assessment of the health benefits of walking or cycling by estimating the value of reduced mortality that results from specified amounts of walking or cycling (HEAT 2011). However, this tool does not consider the type of environment in which walking or cycling occurs (e.g. forest versus coastal environments). In conclusion, the indicators currently available for estimating the impact of forest recreation and tourism on people's health and wellbeing are indirect ones, such as amount and frequency of forest recreation. They are based on research, which suggest that increased exposure to nature is beneficial to human wellbeing (Nilsson et al. 2011).

\subsubsection{Tourism}

It is important to remember that tourism is more than an industry and economic activity. Tourism development often entails community development and if managed well, tourism can be an important engine to achieve broader social goals. A recent publication on community indicators for parks, recreation and tourism management (Budruk and Philips 2011) include topics such as quality-of-life satisfaction, publicly accessible space, sustainability and stakeholder involvement. Since tourism may involve several socio-cultural benefits (e.g. promotion of crosscultural understanding, social wellbeing, jobs, infrastructure, political stability, and incentives to preserve local culture and heritage) and costs (e.g. introduction of undesirable activities, racial tensions, loss of cultural pride, and crime), the field of tourism has developed many different forms of social indicators to monitor these issues.

The World Tourism Organization (2013) uses the following indicators to monitor the development of tourism globally: Inbound Tourism: International Tourist Arrivals; International Tourism Receipts; and Outbound Tourism: International Tourism Expenditure; Outbound Tourism by Region of Origin. The WTO has also developed a "Global Code of Ethics for Tourism" which is a comprehensive set of principles designed to guide key-players in tourism development to help maximize the sector's benefits while minimizing its potentially negative impact on the environment, cultural heritage and societies across the globe (Global Code... 2013). The code's ten principles cover economic, social, cultural and environmental aspects of travel and tourism: 
- Article 1: Tourism's contribution to mutual understanding and respect between peoples and societies.

- Article 2: Tourism as a vehicle for individual and collective fulfilment.

- Article 3: Tourism, a factor of sustainable development.

- Article 4: Tourism, a user of the cultural heritage of mankind and contributor to its enhancement.

- Article 5: Tourism, a beneficial activity for host countries and communities.

- Article 6: Obligations of stakeholders in tourism development

- Article 7: Right to tourism.

- Article 8: Liberty of tourist movements.

- Article 9: Rights of the workers and entrepreneurs in the tourism industry.

- Article 10: Implementation of the principles of the Global Code of Ethics for Tourism.

For example, under Article 3 it says that "All the stakeholders in tourism development should safeguard the natural environment with a view to achieving sound, continuous and sustainable economic growth geared to satisfying equitably the needs and aspirations of present and future generations" and "Nature tourism and ecotourism are recognized as being particularly conducive to enriching and enhancing the standing of tourism, provided they respect the natural heritage and local populations and are in keeping with the carrying capacity of the sites." Article 5 states that "Local populations should be associated with tourism activities and share equitably in the economic, social and cultural benefits they generate, and particularly in the creation of direct and indirect jobs resulting from them."

\subsubsection{Nature-based tourism and eco-tourism}

Looking at nature-based tourism specifically, sustainable use of natural resources (e.g. forests) and management of the physical setting is often an integrated part of social sustainability. Considering nature-based tourism from a sustainability perspective will inevitably take us to the concept of ecotourism, which can be seen as a normative sub-category of nature-based tourism. Donohoe and Needham (2006) reviewed 42 definitions and conclude that ecotourism is characterized as nature-based, preservative, educative, sustainable, responsible and ethical tourism. In addition to the nature-based component, these are all normative features guiding us how ecotourism should be performed. 
As one example of indicators developed in an eco-tourism context we can refer to the Swedish eco-tourism labelling system "Nature's best" (2013). They operate from the following definition of ecotourism Ecotourism is responsible travel to natural areas that contributes to the conservation of natural habitats and sustains the well-being of local people and have developed a large number of criteria (basic and bonus) within six fields:

\section{Respect the limitations of the destination - minimize negative impact on nature and culture}

The ecological and social carrying capacity of the destination has to be respected and the quality of the visitor experience needs to be safeguarded. Examples of criteria are:

- Travel destination analysis: codes of conduct

- Group size limitations may apply

- Landowner agreements (Right of Public Access)

- Protected area regulations respected

- Dialogue with nature conservation and Samí authorities

- Special evaluation of hunting, fishing, etc.

\section{Support the local economy}

Ecotourism means to integrate tourism development and share the benefits at the community level. Each tour product should in the best possible way contribute to the local economy by local sourcing, purchasing as much as possible in the area. Examples of criteria are:

- A company policy to give a "local colour" to all activities.

- The operator contributes to some local development work.

- As much as possible of the products and services are purchased locally.

- Visitors are encouraged to buy locally.

\section{Make all the company's operations environmentally sustainable}

Ecotourism operators are pioneers of best practice environmental management. The goal is for all parts of the company's operations to be as eco-friendly as possible. Examples of criteria are:

- The operator has a plan describing environmental impact and improvements needed (available to customers).

- There is a controller in charge of plan.

- The operator should use environmentally friendly technology and environmental labelled products when possible.

- Routines for waste disposal. 
- Train and bus transportation offered when possible.

- Motorized transportation in back-country minimized.

- Insecticides and herbicides are avoided.

\section{Contribute actively to conservation}

Ecotourism means to take responsibility for biodiversity and the unique values of nature and culture. It promotes and co-operates with a nature conservation opinion and reaps the benefits of it. It is a partnership for mutual benefit. Examples of criteria are:

- Support is given to some nature or culture conservation program or organization.

- The operator is a member of a nature conservation organization.

- The operator provides information about nature or culture conservation projects at the destination.

\section{Promote the joy of discovery, knowledge and respect}

Ecotourism means to travel with both a curious and respectful attitude. The personal encounter with the traveller is in focus. Skilled and competent guides will transmit the joy of discovery and knowledge. Examples of criteria are:

- All staff and guides have good knowledge about the destination's natural and cultural values.

- Travellers receive pre-tour information about the destination.

- The product includes personal information about the destination and "Right of Public Access."

- In groups without guide one participant appoints responsibility for environmental impact during trip.

\section{Quality and safety all the way through}

Ecotourism means quality tourism, and labelled products keep high standards from beginning to end. An approved tour operator is characterized by: serious entrepreneurship, responsible marketing, payment ethics, and by having all the legal documents in order. Examples of criteria are:

- The operator has a minimum of 2 years of professional experience.

- The operator is registered with the Swedish tax authorities, has a liability insurance and travel guarantee.

- The operator continuously improves the quality of the product and works with post trip customer feed-back.

- Customers are informed about the ecotourism labelling system. 


\subsubsection{Tourism in protected areas}

Protected areas, such as World Heritage Sites, National Parks etc., are another context where indicators for socially and ecologically sustainable tourism have been recognized. Parks and protected areas do not only provide protection of plants and animals; they offer many social values in terms of recreation opportunities, nature experiences and tourism attractions. Given the importance of such values to society, we need to consider how to better manage these places and activities for visitors. Management is required to ensure that standards of quality are maintained and management objectives accomplished, and determining acceptable levels of change in parks and protected areas is based largely on associated indicators and standards of quality (Manning and Anderson 2012). A large number of indicators exist around the world, and for an overview we recommend Manning (2007). Among the indicators frequently found in such systems are: number of visitors, number of campsites, length of trails, evidence of litter, impact on ground and vegetation, encounters, visitor facilities, behaviour of visitors, visitor expenditures, and visitor satisfaction. Manning (2007 p.28) lists the following characteristics of good indicators in a parks and protected area context:

- Specific (rather than general)

- Objective (rather than subjective)

- Repeatable

- Sensitive to the subject they measure

- Manageable (responsive to management actions)

- Efficient and effective to measure

- Integrative (proxies for more than one indicator)

- Significant (help define quality parameters). 


\section{Overview of nature-based recreation policies and indicators in North European countries}

Tuija Sievänen, David Edwards, Peter Fredman, Frank S. Jensen and Odd Inge Vistad

The aim of this report is to offer relevant information for further development of social indicators of forestry (with particular focus on naturebased recreation and tourism) and their monitoring in a North European context. The descriptions of status of indicators and monitoring in specific countries are compiled in Appendix 1 in this report, while this chapter provides a summary of those reports.

The following three tables, in which information from different countries is brought together, offer a summary of how recreation and tourism is represented in different types of policy documents in different sectors (table 2), what kind of indicators are included in different documents (table 3), and what kind of sources of data and information are used for monitoring recreation indicators (table 5).

The first task was to report how nature-based recreation and tourism is represented in policy documents, and whether any statements exist which support use of indicators and monitoring for the purpose of sustainable use of natural resources or land use. We have included integration of land uses, integration of recreation and tourism with timber production, nature conservation or mining and other extractive use of natural resources, and other political goals such as human health and wellbeing in respect of use of land and natural resources. One important aspect is the sustainability of recreational use itself. Most countries were able to put forward policy documents, which are related to natural resources, tourism, land use planning or health sector, and in which nature-based recreation and/or tourism are mentioned as having a role in the sector (table 2). The most typical type of document was a national 
forest program or strategy. Most of the documents reported were strategy reports, but also some inventories and development plans were reported. All of the countries are participants in the FOREST EUROPE reporting process. Only four countries (Denmark, Finland, Norway and Sweden) have a specifically focused strategy or program for outdoor recreation and/or nature-based tourism.

Table 2: Recreation and tourism in policy documents

\begin{tabular}{|c|c|c|c|c|}
\hline Country & $\begin{array}{l}\text { National forest program or } \\
\text { strategy, SFM-reports, } \\
\text { certification, legislation }\end{array}$ & $\begin{array}{l}\text { National nature-based } \\
\text { recreation and tourism } \\
\text { program, strategy, other } \\
\text { document }\end{array}$ & $\begin{array}{l}\text { Other national program, } \\
\text { strategy }\end{array}$ & $\begin{array}{l}\text { Participation } \\
\text { in FOREST } \\
\text { EUROPE } \\
\text { reporting }\end{array}$ \\
\hline Estonia & $\begin{array}{l}\text { Estonian Forestry Develop- } \\
\text { ment Plan } 2020\end{array}$ & $\begin{array}{l}\text { Estonian National Tourism } \\
\text { Development Plan 2007-2013 }\end{array}$ & $\begin{array}{l}\text { National Spatial Plan } \\
\text { Nature Conservation Devel- } \\
\text { opment Plan } 2020 \\
\text { Estonian Environmental } \\
\text { Strategy } 2030 \\
\text { National Health Plan 2009- } \\
2020\end{array}$ & Yes \\
\hline Denmark & National Forest Program & $\begin{array}{l}\text { Danish National Outdoor } \\
\text { Recreation Policy (under } \\
\text { development, expected early } \\
\text { 2014, Ministry of Environment) } \\
\text { Strategy and Manual for } \\
\text { Outdoor Recreation Statistics } \\
2008\end{array}$ & $\begin{array}{l}\text { Strategy for the Danish Out- } \\
\text { door Council 2013-2020 }\end{array}$ & Yes \\
\hline Finland & $\begin{array}{l}\text { National Forestry Program } \\
2015 \\
\text { Natural Resources Strategy } \\
2009 \\
\text { Certification PEFC and FSC }\end{array}$ & $\begin{array}{l}\text { Program for Development of } \\
\text { Outdoor Recreation and } \\
\text { Tourism } 2010 \text { (2002) } \\
\text { Guidebook of Everyman's } \\
\text { Rights } 2012\end{array}$ & $\begin{array}{l}\text { Finland's Tourism Strategy } \\
2011 \\
\text { The Strategy for Protection of } \\
\text { Biodiversity and Sustainable } \\
\text { Use } 2007\end{array}$ & Yes \\
\hline Lithuania & & & & \\
\hline $\begin{array}{l}\text { Northern } \\
\text { Germany }\end{array}$ & $\begin{array}{l}\text { Federal Forest Act: Right of } \\
\text { Access for Recreation Purposes } \\
\text { The Forest Report by Federal } \\
\text { Government } 2009 \\
\text { Sustainability Strategy } \\
\text { Forest Strategy } 2020 \\
\text { National Forest Program } \\
\text { Certification FSC and PEFC }\end{array}$ & & Biodiversity Strategy & Yes \\
\hline $\begin{array}{l}\text { North } \\
\text { Western } \\
\text { Russia }\end{array}$ & $\begin{array}{l}\text { Russian Federation Forest } \\
\text { Code } \\
\text { Regulation of Forest Usage } \\
\text { for Implementation of Recre- } \\
\text { ational Activity }\end{array}$ & & Russian Federation Land Code & \\
\hline Norway & $\begin{array}{l}\text { Forestry Act } 2005 \\
\text { Agriculture and Food Policy } \\
2011 \\
\text { PEFC Standard } 2010 \\
\text { Nature Diversity Act } 2009 \\
\text { Outdoor Recreation Act } 1957\end{array}$ & $\begin{array}{l}\text { White paper on Outdoor } \\
\text { Recreation (MD 2001) } \\
\text { Goals and Knowledge Needs } \\
\text { in Environmental Manage- } \\
\text { ment (MD 2010) } \\
\text { National Strategy for Active } \\
\text { Outdoor Recreation } 2013\end{array}$ & $\begin{array}{l}\text { State of Environment Norway } \\
\text { website }\end{array}$ & Yes \\
\hline
\end{tabular}




\begin{tabular}{|c|c|c|c|c|}
\hline Country & $\begin{array}{l}\text { National forest program or } \\
\text { strategy, SFM-reports, } \\
\text { certification, legislation }\end{array}$ & $\begin{array}{l}\text { National nature-based } \\
\text { recreation and tourism } \\
\text { program, strategy, other } \\
\text { document }\end{array}$ & $\begin{array}{l}\text { Other national program, } \\
\text { strategy }\end{array}$ & $\begin{array}{l}\text { Participation } \\
\text { in FOREST } \\
\text { EUROPE } \\
\text { reporting }\end{array}$ \\
\hline Scotland & $\begin{array}{l}\text { UK Sustainable Forest Man- } \\
\text { agement Indicators } 2010 \\
\text { UK Indicators of Sustainable } \\
\text { Forestry } 2002 \\
\text { Scottish Forestry Strategy } \\
\text { UK Woodland Assurance } \\
\text { Standard (UKWAS) } \\
\text { UK Forest Standard (UKFS) }\end{array}$ & $\begin{array}{l}\text { Scottish Outdoor Access Code } \\
\text { Land Reform (Scotland) Act }\end{array}$ & $\begin{array}{l}\text { Scotland Performs } \\
\text { Scotland Land Use Strategy } \\
\text { Scottish Biodiversity Strategy } \\
\text { Tourism Scotland } 2020 \text { (Na- } \\
\text { tional tourism strategy, } \\
\text { published 2012) }\end{array}$ & Yes \\
\hline Sweden & $\begin{array}{l}\text { Swedish National Forest } \\
\text { Policy 2007-2008 }\end{array}$ & $\begin{array}{l}\text { Swedish Outdoor Recreation } \\
\text { Policy } \\
\text { Swedish Ecotourism Certifica- } \\
\text { tion System }\end{array}$ & $\begin{array}{l}\text { National environmental } \\
\text { objectives } \\
\text { Protect, Preserve, Present- } \\
\text { Program for Environmental } \\
\text { Protection 2008-2009 } \\
\text { Swedish Public Health Policy } \\
2007\end{array}$ & yes \\
\hline
\end{tabular}

The second task was to collect lists of indicators presented in official documents or in other literature such as study or review reports of recreation indicators (table 3). Most countries report some indicators related to recreation. In Denmark, Scotland and Sweden, several different indicators are found in different documents, which raise the issue of harmonization. Norway has some official outdoor recreation indicators, but not specified for forest recreation (Engelien 2012, State of... 2013). There is a lot of variation between the existing indicators, and, apart from FOREST EUROPE Indicator 6.10, there doesn't appear to be one that is common to all countries. In most countries, the list of indicators adopted in "official documents" is surprisingly short. 
Table 3: Examples of recreation and tourism indicators, which are either used or proposed

\begin{tabular}{|c|c|c|}
\hline Country & National level & Local level/ecosystem specific \\
\hline Estonia & $\begin{array}{l}\text { Investments appointed at recreation purpos- } \\
\text { es in state forests } \\
\text { Providing an environment and infrastructure } \\
\text { that supports physical activity } \\
\text { Regular monitoring and assessment of } \\
\text { exercise habits of population }\end{array}$ & \\
\hline Denmark & $\begin{array}{l}\text { Several (like for Scotland and Sweden). None } \\
\text { is officially adopted }\end{array}$ & \\
\hline Finland & $\begin{array}{l}\text { Participation rate in outdoor recreation by } \\
\text { population and in age groups } \\
\text { Number of recreation occasions in close-to } \\
\text { home nature per year } \\
\text { Time used for recreation, hours per week } \\
\text { Participation rate and frequency of forest } \\
\text { recreation activities (berry and mushroom } \\
\text { picking, hunting) } \\
\text { Number and length of managed recreation } \\
\text { trails for walking, hiking and cross-country } \\
\text { skiing }\end{array}$ & $\begin{array}{l}\text { local economic impact on protected } \\
\text { and recreational state owned areas }\end{array}$ \\
\hline Lithuania & & \\
\hline Northern Germany & Value of forest-based recreation & Value and size of recreation forest \\
\hline $\begin{array}{l}\text { North Western } \\
\text { Russia }\end{array}$ & No & \\
\hline Norway & $\begin{array}{l}\text { Key examples include: } \\
\text { Proportion of the population who take part in } \\
\text { outdoor recreation activities } \\
\text { Number of schools taking part in the "Envi- } \\
\text { ronmental rucksack" project } \\
\text { Number and percentage of new outdoor } \\
\text { recreation areas designated per year with } \\
\text { financial assistance from the state } \\
\text { Proportion of population with short distance } \\
\text { to local green areas }\end{array}$ & \\
\hline Scotland & $\begin{array}{l}\text { Key examples include: } \\
\text { Proportion of adults making one or more } \\
\text { visits to the outdoors per week } \\
\text { Number of communities involved in owning } \\
\text { or managing woodland } \\
\text { Proportion of schools involved in woodland } \\
\text { based learning activities } \\
\text { Number of people who use woodland for } \\
\text { exercise } \\
\text { Number of volunteers involved in woodland } \\
\text { based activities } \\
\text { Proportion of population with accessible } \\
\text { woodland greater than } 2 \text { ha within } 500 \text { m of } \\
\text { their home } \\
\text { Proportion of adults who visited woodland in } \\
\text { previous } 12 \text { months } \\
\text { Number of visits to national forests } \\
\text { Number and length of core paths in wood- } \\
\text { lands } \\
\text { Health in woodlands }\end{array}$ & \\
\hline
\end{tabular}




\begin{tabular}{lll}
\hline Country & National level & Local level/ecosystem specific \\
\hline Sweden & Key examples include: & Key examples include: \\
& The proportion of the population which has & Untouched green space: Old-growth \\
less than 300 meters from their residence to a & forest, low noise levels, 250 meters \\
nature area which makes the individual feel & from roads and facilities \\
physically and mentally well. & Woodland harmony: Continuous forest \\
& Proportion of the population which has less & area, low noise level, 250 meters from \\
than 300 meters from their residence to four & roads and facilities \\
nature- and/or culture areas. & Open views and open landscapes: Lakes, \\
& Number of visits in different types of areas, & viewpoints and open landscapes. \\
& for example parks, nature reserves, cultural & Biodiversity and lessons from nature: \\
areas and facilities & Biodiversity, pastures, wetlands, low \\
Indicators of outdoor recreation in the & noise level, trails, visitor centers. \\
national environmental and outdoor recrea- & Cultural history and living environ- \\
tion policies is currently under development & ment: Open farmland, cultural heritage \\
(September, 2013) & objects. \\
& $\begin{array}{l}\text { Activities and challenges: Trails, tracks, } \\
\text { facilities, outdoor pools, lakes, fitness }\end{array}$ \\
& centers. \\
& Facilities and meeting places: Re- \\
& strooms, dressing-rooms, visitor centers, \\
& cafeteria, information, fitness centers. \\
\hline
\end{tabular}

When summarizing indicators, "number of visits to land suitable for recreation" or "area accessible for public recreation" are similar to FOREST EUROPE indicators, and thus they are most common. In national documents, "participation in outdoor recreation" or "specified maximum distance to land suitable for recreation" are among the most common to all reviewed countries. More indicators are related to demand of recreation than to supply of recreation opportunities, but there are also a number of economic indicators in use (table 4). 


\begin{tabular}{|c|c|c|}
\hline Demand Indicators & Supply Indicators & Other (economic etc.) \\
\hline $\begin{array}{l}\text { Number of visits to land suitable } \\
\text { for recreation }\end{array}$ & Area accessible for public recreation & Expenditure on visit \\
\hline Length of the visit & $\begin{array}{l}\text { Specified maximum distance to } \\
\text { land suitable for recreation }\end{array}$ & $\begin{array}{l}\text { Non-market value of visits to } \\
\text { forests (e.g. health benefits) }\end{array}$ \\
\hline Frequency of visits & $\begin{array}{l}\text { Specified minimum nature area } \\
\text { suitable for recreation }\end{array}$ & $\begin{array}{l}\text { Investments appointed at } \\
\text { recreational purposes in state } \\
\text { forests }\end{array}$ \\
\hline $\begin{array}{l}\text { Participation and main trends } \\
\text { (most popular activities, geo- } \\
\text { graphical variation etc.) in } \\
\text { recreation activities }\end{array}$ & $\begin{array}{l}\text { Amount of different kinds of nature } \\
\text { areas: forests, national parks, } \\
\text { recreational areas, protected areas, } \\
\text { green spaces in urban areas etc. }\end{array}$ & $\begin{array}{l}\text { Willingness to pay for the } \\
\text { existence of land suitable for } \\
\text { recreation }\end{array}$ \\
\hline $\begin{array}{l}\text { Proportion of the population who } \\
\text { take part in environmental } \\
\text { education (e.g. in kindergartens } \\
\text { and schools or during leisure time) }\end{array}$ & $\begin{array}{l}\text { Quality of recreation area: environ- } \\
\text { mental state, forest feeling, culture, } \\
\text { services, activity possibilities etc. }\end{array}$ & \\
\hline $\begin{array}{l}\text { Knowledge of outdoor recreation } \\
\text { opportunities }\end{array}$ & $\begin{array}{l}\text { Number and length of trails and } \\
\text { paths on lands suitable for recrea- } \\
\text { tion }\end{array}$ & \\
\hline Visitor satisfaction & $\begin{array}{l}\text { Information about recreation } \\
\text { opportunities }\end{array}$ & \\
\hline
\end{tabular}

The third topic for reporting was the sources of data and information that are used for monitoring recreation indicators (table 5). The objective was to determine who is responsible for the provision of monitoring data, what the quality of the data is and whether the data is updated systematically. Another important aspect is to determine the prospects of data collection continuing into the future. Finally, one key task was to find out whether there is any systematic monitoring or data available for the indicators related to recreation and tourism, which could serve as data sources for recreation indicators but which are not in use at the moment. Most countries report that there is some kind of monitoring system or database, which is or could be used for monitoring recreation indicators (table 5). Many countries also report that there is some systematic data collection both at national and local level, and both from a demand and a supply perspective. But in most countries the data collection is not primarily for monitoring nature-based recreation. Only Denmark, Finland, Norway and Scotland can report having especially focused monitoring for outdoor recreation nationwide. Estonia, Denmark, Finland and Scotland have regularly conducted on-site visitor surveys, but the local/on-site level monitoring is mainly concentrated on state owned areas. Denmark and Scotland have the best coverage of visitor surveys and counting. Denmark, Estonia, Finland, Norway, Northern Germany and Sweden gath- 
er outdoor recreation related statistics with surveys such as Living conditions, Time Use, Environmental awareness, Culture and Leisure, or with general National Statistics such as in Germany.

Table 5: Monitoring and reporting of recreation and tourism indicators

\begin{tabular}{|c|c|c|c|c|}
\hline Country & $\begin{array}{l}\text { Recreation Demand } \\
\text { National Surveys }\end{array}$ & $\begin{array}{l}\text { Recreation Supply } \\
\text { National Inventory } \\
\text { /Study/Database }\end{array}$ & $\begin{array}{l}\text { Other sources of } \\
\text { data on national } \\
\text { level }\end{array}$ & $\begin{array}{l}\text { Local level/on-site } \\
\text { monitoring }\end{array}$ \\
\hline Estonia & $\begin{array}{l}\text { Nation Wide Recrea- } \\
\text { tion Studies (concern } \\
\text { state owned areas) } \\
\text { (EAS)-domestic trips } \\
\text { during the summer- } \\
\text { time among Estonian } \\
\text { people }\end{array}$ & & $\begin{array}{l}\text { National Survey } \\
\text { of Environmental } \\
\text { Awareness } \\
\text { Statistics Estonia- } \\
\text { time use surveys } \\
\text { Enterprise } \\
\text { Estonia }\end{array}$ & $\begin{array}{l}\text { Visitor Surveys in } \\
\text { state owned recrea- } \\
\text { tional areas } \\
\text { Visitor Counting } \\
\text { Study on the social } \\
\text { carrying capacity of } \\
\text { the population living } \\
\text { close to recreation } \\
\text { areas }\end{array}$ \\
\hline Denmark & $\begin{array}{l}\text { National Outdoor } \\
\text { Recreation Demand } \\
\text { Survey }(1977,1994 \text {, } \\
\text { 2008) }\end{array}$ & $\begin{array}{l}\text { National Forest } \\
\text { Inventory } \\
\text { Database of recrea- } \\
\text { tion facilities on state } \\
\text { land. }\end{array}$ & $\begin{array}{l}\text { Culture and } \\
\text { Leisure Surveys }\end{array}$ & $\begin{array}{l}\text { Permanent automat- } \\
\text { ic counting ( } 4 \text { sites). } \\
\text { Acyclic visitor surveys } \\
\text { and counts in princi- } \\
\text { pal all state owned } \\
\text { forest and a number } \\
\text { of voluntary private } \\
\text { forests. } \\
\text { One-time surveys } \\
\text { and counts at single } \\
\text { forest areas. }\end{array}$ \\
\hline Finland & $\begin{array}{l}\text { National Outdoor } \\
\text { Recreation Demand } \\
\text { Inventory-survey } \\
\text { (LVVI),1998-2000, } \\
\text { 2009-2010 }\end{array}$ & $\begin{array}{l}\text { National databank of } \\
\text { recreational areas, } \\
\text { trails and services } \\
\text { (LIPAS+VIRGIS); only } \\
\text { state owned areas } \\
\text { and services are well } \\
\text { represented }\end{array}$ & $\begin{array}{l}\text { Leisure Surveys } \\
\text { Time Use } \\
\text { Surveys, both by } \\
\text { Statistics Finland }\end{array}$ & $\begin{array}{l}\text { Visitor surveys and } \\
\text { counts in national } \\
\text { parks and hiking } \\
\text { areas on state land } \\
\text { Databank of recrea- } \\
\text { tion services provid- } \\
\text { ed by state }\end{array}$ \\
\hline \multicolumn{5}{|l|}{ Lithuania } \\
\hline $\begin{array}{l}\text { Northern } \\
\text { Germany }\end{array}$ & $\begin{array}{l}\text { Nationwide surveys } \\
\text { of economic value }\end{array}$ & $\begin{array}{l}\text { Federal Test Enter- } \\
\text { prise network }\end{array}$ & $\begin{array}{l}\text { National Stati- } \\
\text { stics }\end{array}$ & \\
\hline $\begin{array}{l}\text { North } \\
\text { Western } \\
\text { Russia }\end{array}$ & & $\begin{array}{l}\text { Inventory of forests } \\
\text { recreation assignment } \\
\text { (FRA) }\end{array}$ & & \\
\hline Norway & $\begin{array}{l}\text { National studies on } \\
\text { motives for outdoor } \\
\text { recreation, and on } \\
\text { geographical/distance } \\
\text { constraints/barriers }\end{array}$ & $\begin{array}{l}\text { Statistics Norway: } \\
\text { Proportion of popula- } \\
\text { tion with short } \\
\text { distance to local } \\
\text { green areas }(<500 \\
\mathrm{m} /<200 \mathrm{~m}) .\end{array}$ & $\begin{array}{l}\text { National survey } \\
\text { of level of } \\
\text { living/outdoor } \\
\text { recreation } \\
\text { participation }\end{array}$ & $\begin{array}{l}\text { Only in some urban } \\
\text { forests and protected } \\
\text { areas. }\end{array}$ \\
\hline
\end{tabular}




\begin{tabular}{|c|c|c|c|c|}
\hline Country & $\begin{array}{l}\text { Recreation Demand } \\
\text { National Surveys }\end{array}$ & $\begin{array}{l}\text { Recreation Supply } \\
\text { National Inventory } \\
\text { /Study/Database }\end{array}$ & $\begin{array}{l}\text { Other sources of } \\
\text { data on national } \\
\text { level }\end{array}$ & $\begin{array}{l}\text { Local level/on-site } \\
\text { monitoring }\end{array}$ \\
\hline Scotland & $\begin{array}{l}\text { Forestry Commission } \\
\text { Recreation Statistics } \\
\text { (surveys conducted) } \\
\text { UK Day Visits Survey } \\
\text { Scottish Recreation } \\
\text { Survey 2003-2013 } \\
\text { Scotland Visitor } \\
\text { Survey (Visit Scot- } \\
\text { land) } \\
\text { Forestry Commission } \\
\text { Public Opinion of } \\
\text { Forestry Survey } \\
\text { Forestry for People } \\
\text { (F4P) study } 2009\end{array}$ & $\begin{array}{l}\text { National Forest } \\
\text { Inventory (includes } \\
\text { social indicators, e.g. } \\
\text { paths; access; } \\
\text { ownership) }\end{array}$ & & $\begin{array}{l}\text { Forestry Commission } \\
\text { All Forests Monitor- } \\
\text { ing (visitor survey } \\
\text { and counts in the } \\
\text { national forest estate } \\
\text { in Scotland) } \\
\text { Forestry Commission } \\
\text { Quality of Experience } \\
\text { surveys } \\
\text { Forest Visitor Surveys } \\
\text { and Counts (of } \\
\text { individual public } \\
\text { forests) }\end{array}$ \\
\hline Sweden & $\begin{array}{l}\text { Living Conditions } \\
\text { Survey by Statistics } \\
\text { Sweden; outdoor } \\
\text { activities followed } \\
\text { since } 1976 \text { (five } \\
\text { times) } \\
\text { Suggested: "a } \\
\text { national program for } \\
\text { outdoor recreation } \\
\text { statistics, 2009" }\end{array}$ & $\begin{array}{l}\text { A nation-wide } \\
\text { inventory of forests } \\
\text { with high social } \\
\text { values by Swedish } \\
\text { National Board of } \\
\text { Forestry (currently } \\
\text { on hold) } \\
\text { Inventory of urban } \\
\text { proximate green } \\
\text { wedges } \\
\text { Inventory of nature- } \\
\text { based tourism supply } \\
\text { by Etour }\end{array}$ & $\begin{array}{l}\text { Environmental } \\
\text { Monitoring and } \\
\text { Assessment } \\
\text { (EMA) } \\
\text { National Inven- } \\
\text { tory of the } \\
\text { Swedish Land- } \\
\text { scape (NILS) } \\
\text { National de- } \\
\text { mand survey in } \\
2007 \text { by re- } \\
\text { search program } \\
\text { "Friluftsliv i } \\
\text { Förändring" }\end{array}$ & $\begin{array}{l}\text { On-site visitor } \\
\text { monitoring in select- } \\
\text { ed areas (regional } \\
\text { level). No systematic } \\
\text { approach. }\end{array}$ \\
\hline
\end{tabular}




\section{Summary and conclusions}

Tuija Sievänen, David Edwards, Peter Fredman, Frank S. Jensen and Odd Inge Vistad

\subsection{Indicators and monitoring related to nature- based recreation and tourism}

This report presents the results of the SOSIN project (Social indicators in forestry - further development in the North European context). The aim of the project was to gather scientists and other experts from Northern Europe to discuss how to proceed with the challenge of social indicators and monitoring of changes to social benefits, particularly recreation and tourism, in the context of forestry and forest use. The task was to produce a review report of the state of art in North European countries.

First, there was a need for collecting information from participating countries (Denmark, Estonia, Finland, Lithuania, Northern Germany, Northeastern Russia, Norway, Scotland and Sweden) in terms of the use and monitoring of social indicators in different sectors of society, particularly in forestry. One important part of the project was to discuss and to get understanding of the status of the current FOREST EUROPE panEuropean indicators for Sustainable Forest Management and their reporting in the North European context. All this information will serve as background for the further work of the project, which is to produce a project plan for standardization and harmonization of social indicators for monitoring and management of sustainable forestry and forest use, and for sustainable nature-based recreation and tourism.

Almost all North European countries seem to have governmental policy documents, which include some consideration of nature-based recreation and tourism in the context of natural resources, tourism, land use planning or health and wellbeing affairs. Most of the documents reported were strategy statement reports, but also some development plan documents were reported. The most typical type of document was a national forest program or strategy. All of the countries are participants in the FOREST EUROPE reporting process. Only four countries (Denmark, Finland, Norway and Sweden) have a specifically focused strategy 
program for outdoor recreation and/or nature-based tourism. Norway seems to have the strongest legislative basis for outdoor recreation. Sweden has an interesting process going on which eventually might end up with new indicators as well as a national inventory.

Most countries were able to report a set of indicators related to naturebased recreation and tourism, either proposed or in use. In Denmark, Norway, Scotland and Sweden, a larger set of different indicators are found in different documents. There is much variation between the existing indicators, and few indicators appear to be applicable to all countries under current conditions. As our aim of the SOSIN project was to identify common indicators, we can conclude that we see, however, good potentials to develop common indicators for the North European countries.

Most countries report that there is some kind of monitoring system or database, which is or could be used for monitoring recreation indicators (table 3). Many countries also report that there is some systematic data collection both on national and local level, and both from a demand and a supply perspective. But in most countries the data collection is not primarily for monitoring of nature-based recreation.

The project identified several problems with current social indicators of nature-based recreation and tourism. In most countries, the relevant indicators are not feasible and effective to offer reliable information of on-going changes. The major problem in most countries is that there is a serious shortage of reliable data to provide quantitative figures for social indicators. According to COST E33 reporting, most European countries lack efficient monitoring systems to offer estimates of indicators across time and regions (Sievänen et al. 2008). Recreation monitoring is taking place in most North European countries to some extent, but less so in other parts of Europe. But also in the North monitoring methods and outputs accordingly vary a lot between countries. There are efforts to include recreation measurements into forest inventory systems (Danish National Forest Inventory), or there are national outdoor recreation demand inventories (Denmark, Finland, Scotland), and in some countries there are databases of recreation supply (of recreation areas, trails, other services). It is critical to develop both indicators and monitoring at the same time as these are dependent on each other.

Also, indicators presented are often not directly measuring demand or supply of recreation, or other aspects of recreation but rather values that are indirectly related. Those indicators are chosen because the data are available, but there is a danger that the indicators are not effective to capture the key issue. A big problem is that there are no reliable measurements to offer for reporting sustainability (or equity), and few coun- 
tries can provide time series for national or regional level information, which is needed to describe the status of the indicators. Finally, there are not always standards for the information with which to describe the indicators, and thus information gathered may not be comparable between countries (see example of FOREST EUROPE Indicator 6.10).

\subsection{FOREST EUROPE indicators}

Appendix 2 analyses the FOREST EUROPE Indicator 6.10 "Intensity of use" ("Area of forest and other wooded land where public has right of access for recreational purposes and indication of intensity of use)." This is based on the data and comments provided by countries for the "State of Europe's Forests" (SOEF) reports 2011 and 2007, and the individual country reports. The report reveals that only 15 out of 45 participating countries provided estimates for "intensity of use" for the reporting year 2005. Of the 15 countries, ten appear to have provided data for numbers of visits to all forests in their respective countries, including Denmark, Lithuania, Norway, and UK. Five countries including Estonia and Russian Federation provided estimates, which only cover a small proportion of the forest area, typically National Parks. For nearly all countries, other assumptions were not made explicit in any of the SOEF reporting, in particular the age range of respondents, whether the definition of a visit deviated from the one given in the enquiry, and whether the definition included visits made while staying away from home, visits by overseas tourists, and visits not considered leisure e.g. routine dog walking.

The level of Forest Europe reporting suggests that the quality of the data could be improved if the need to specify further information is made more explicit in the reporting form: a) the area of forest and other wooded land covered by the estimate, b) the definition of visits that was used, c) the primary data sources. In future, assuming countries provide this information for SOEF 2015, clarifications are needed concerning which of the estimates for "intensity of use" only referred to a subset of total forest cover. Otherwise, the variations in intensity of use between countries are likely to be misinterpreted. The other aspect here concerns how reliable countries are able to report numbers of visits, as the status of monitoring is rather low in most European countries (Sievänen et al. 2008). The problem is that SOEF reports and individual country reports do not give enough information on methods used to estimate number of visits as a basis for recommending improved approaches to be used across Europe. Based on our review, we conclude that most countries have problems 
reporting the current FOREST EUROPE social indicators, including 6.10, which is of most relevance to recreation and nature-based tourism.

The current FOREST EUROPE indicators are difficult to measure across all countries, and the information provided may not be comparable after all. This situation indicates that some of the social indicators included in the MPCFE process should be evaluated, and a process to create comparable and harmonized indicators should be initiated in the near future. Our report, on behalf of North European countries, offers one contribution in this respect. It is timely to evaluate possible social/recreation indicators, and to look for possibilities to harmonize and to standardize methodologies, and some key variables to be measured in order to get comparable statistics and indicators in (North) European countries. It is also good to look for possibilities for information and experience transfer between countries. Those countries with less experience of recreation monitoring and indicators can learn from experiences of more advanced countries. A common project, in which many European countries participate, could be a good platform to exchange information and experiences. One helpful tool already exists for monitoring local level recreation demand information: there is a manual "Visitor monitoring in nature areas" for visitor monitoring based a experiences in Nordic-Baltic countries (Kajala et al. 2007). But more is needed for national level recreation demand inventories as well as for databases of supply of recreation opportunities. Developing social indicators and monitoring systems in cooperation may provide more innovative and stable indicator systems and monitoring tools compared to situation where countries are working separately. However, the most important benefit of international cooperation is to establish a good documentation system of nature-based recreation and tourism, which allow monitoring of sustainable use of natural resources for recreation, and also sustainability of recreation and tourism benefits and outcomes among populations.

\subsection{Challenges and actions for the future}

There is an obvious need to enhance the monitoring of social aspects of forests and forestry, and also other sectors in society related to naturebased recreation and tourism. Globalisation continues to have a strong impact on human society across Europe, and European countries will continue to share policies for use of natural resources but also in terms of the status of wellbeing of populations. Good measures and indicators for our societies' success in achieving the objectives of sustainable de- 
velopment are essential and valuable for the wellbeing of people. Our knowledge-base and understanding of the full range of benefits, which people gain from the natural environment when taking part in outdoor recreation, supports the overall goal of enhancing the provision of access to healthy green environments for recreation. The many benefits of improved monitoring of sustainability include long-term positive health and wellbeing impacts on populations as well as healthier and more productive ecosystems. Monitoring sustainability is most importantly a tool for proactive development but it functions also as a tool to show the benefits of sustainable management of forests and other natural resources. Furthermore, monitoring of benefits can be used to raise environmental awareness of the public and to increase the levels of acceptance for forest and other natural resource use and management.

Our next challenge is to work towards relevant and informative indicators that reveal the benefits to our societies. The task is to develop and improve the indicators which are already in use, and also to create new indicators. The indicators should be effective, focused, and be useful for many purposes, also in other sectors of natural resources in North European countries and beyond. There is a need to assess the possibilities of creating and recommending standardized and harmonized social indicators, which could provide comparable figures across countries and regions. Second, the core task is to assess what kind of social, especially recreation, indicators are needed and possible to implement, and what kind of quantitative data is available for collection on a continuous basis in different countries. There is also a need to ensure feasible monitoring systems, which are reasonable in terms of cost and methodology so that many countries can apply them. The potential for using new technologies should be considered here. In all countries included in this study, there is a challenge to develop monitoring systems to produce inventory data for recreation statistics that provide a knowledge-base for indicators that are comparable across Europe. 



\section{References}

Bell, S., Simpson, S., Tyrväinen, L., Sievänen, T. and Pröbstl, U. (eds.) (2008): “European forest recreation and tourism: A handbook." Taylor and Francis, London.

Budruk, M. and Philips, R. (eds.) (2011): "Quality-of-Life Community Indicators for Parks, Recreation and Tourism Management.” Springer, Dordrecht, Heidelberg, London, New York, $230 \mathrm{p}$.

"Criteria and Indicators for the Conservation and Sustainable Management of Temperate and Boreal Forests" (2009). The Montréal Process. Fourth Edition, October 2009. Available at: http://www.montrealprocess.org/documents/publications/ general/2009p_4.pdf. [Cited 5th December 2012].

Donohoe, H.M. and Needham, R.D. (2006): "Ecotourism: The evolving contemporary definition." Journal of Ecotourism Vol.5 No.3, pp. 192-210.

Edwards, D., Elliot, A., Hislop, M, Martin, S., Morris, J., O’Brien, L., Peace, A., Sarajevs, V., Serrand, M. and Valatin, G. (2009): "A valuation of the economic and social contribution of forestry for people in Scotland." Forestry Commission Research Report 101, Forestry Commission Scotland, Edinburgh, 190 p. Available at: http://www.forestresearch.gov.uk/forestryforpeople. [Cited 22nd July 2013].

Engelien, E. (2012): “Tilgang til rekreasjonsareal og nærturterreng. Dokumentasjon av metode." SSB Notater 20/2012. Available at: http://www.ssb.no/arealrek/om.html. [Cited 29th July .2013].

Fredman, P. and Tyrväinen, L. (2010): "Frontiers in Nature-Based Tourism." Scandinavian Journal of Hospitality and Tourism Vol. 10 No.3, pp. 177-189.

"Global Code of Ethics for Tourism" (2013). UNWTO, World Tourism Organization. Available at: http://ethics.unwto.org/en/content/global-code-ethics-tourism. [Cited 23rd July 2013].

"Global Forest Resources Assessment" (2010). Food and Agriculture Organization of the United Nations. Available at: Global Forest Resources Assessment 2010. [Cited 16th August 2013].

Haines-Young, R. and Potschin, M. (2013): "Common International Classification of Ecosystem Services (CICES): Consultation on Version 4, August-December 2012." EEA Framework Contract No EEA/IEA/09/003. Available at: www.cices.eu. [Cited 29th August 2013].

"Healthy Parks Healthy People Central" (2013). Available at: http://www. hphpcentral.com/. [Cited 29th July 2013].

"HEAT, Health Economic Assessment Tool" (2011). World Health Organization. Available at: http://www.heatwalkingcycling.org/. [Cited 23rd July 2013].

Hoffrén, J., Lemmetyinen, I. and Pitkä, L. (2010): “Esiselvitys hyvinvointiindikaattoreista: mittareiden vertailu ja kehittämiskohteet.” Sitran selvityksiä 32, Helsinki. Sitra, 2010. ISBN 978-951-563-727-7, ISSN 1796-7112. Available at: http://www.sitra.fi/julkaisut/Selvityksiä-sarja/Selvityksiä\%2032.pdf. [Cited: 12th July 2012]. 
Jensen, F. S., Skov-Petersen, H. and Johannsen, V. K. (2008): "Friluftslivstatistik: Strategi og manual 2008." Skov \& Landskab, Frederiksberg, 165 p.

Jones, M., and M. Stenseke (eds.) (2011): “The European Landscape Convention: Challenges of participation." Springer, Dordrecht, the Netherlands.

Kajala, L., Almik, A., Dahl, R., Dikšaitè, L, Erkkonen, J., Fredman, P., Jensen, F. Søndergaard, Karoles, K., Sievänen, T., Skov-Petersen, H., Vistad, O. I. and Wallsten, P. (2007): "Visitor monitoring in nature areas - a manual based on experiences from the Nordic and Baltic countries." TemaNord 2007:534. ISBN 91-620-1258-4.

"Landskapets upplevelsevärden - vilka är de och var finns de?" (2007). Boverket, Karlskrona. Available at: http://www.boverket.se/Global/Webbokhandel/ Dokument/2007/landskapets_upplevelsevarden.pdf. [Cited 22nd July 2013].

Manning, R. E. (2007): "Parks and Carrying capacity. Commons without tragedy." Island Press, Washington, Covelo, London, 313 p.

Manning, R.E. and Anderson, L.E. (2012): "Managing Outdoor Recreation. Case Studies in the National Parks." Cabi, Cambridge, 243 p.

MD - Ministry of Environment (2001): "Friluftsliv - Ein veg til høgare livskvalitet" (White paper). St. meld. No. 39 (2000-2001). Miljøverndepartementet, Oslo.

"State of the Environment Norway" (2013). Available at: http://www.environment. no/. [Cited 16th August 2013].

"TEEB - The Economics of Ecosystems and Biodiversity" (2013). Available at: http://www.teebweb.org/. [Cited 16th August 2013].

"The Millennium Ecosystem Assessment" (2013). Available at: http://www.maweb. org/en/index.aspx. [Cited 16th August 2013].

“The Montréal Process" (2013). Available at: http://www.montrealprocess.org/. [Cited 19th July 2013].

"Nature's Best" (2013). The Swedish Ecotourism Society \& VisitSweden. Available at: http://www.naturesbestsweden.com/nb/grundprinciper.asp. [Cited 23rd July 2013].

Nilsson, K., Sangster, M., Gallis, C., Hartig, T., de Vries, S., Seeland, K. and Schipperin. J. (eds.) (2011): "Forests, Trees and Human Health." Springer Science + Business Media, New York, Dordrecht, Heidelberg, London.

"Resolution H1. General Guidelines for the Sustainable Management of Forests in Europe" (1993). Second Ministerial Conference on the Protection of Forests in Europe 16-17 June 1993, Helsinki/Finland. Available at: http://www.foresteurope.org/ docs/MC/MC_helsinki_resolutionH1.pdf. [Cited 29th July 2013].

"Rio Declaration on Environment and Development" (1992). UNCED (United Nations conference on Environment and Development. Rio de Janeiro 2.24.6.1992.

Sievänen, T. (ed.) (2010): "Luontomatkailun, luonnontuotealan, virkistyskäytön ja metsäkulttuurin seurantamittarit." [Indicators for nature-based recreation and tourism, nonwood products and forest culture]. Available at: http://www.metla.fi/ julkaisut/workingpapers/2010/mwp152.htm. [Cited: 22nd July 2013].

Sievänen, T., Arnberger, A., Dehez, J. and Jensen, F.S. (2009): “Monitoring of Forest Recreation Demand.” In: Bell, S., Simpson, S., Tyrväinen, L., Sievänen, T. \& Pröbstl, U. (eds.). "European Forest Recreation and Tourism: A handbook." Taylor and Francis Group Plc., London.

Sievänen, T., Arnberger, A., Dehez, J., Jensen, F.S. and Skov-Petersen, H. (eds.) (2008): "Forest Recreation Monitoring - a European Perspective." Metlan työraportteja / Working Papers of the Finnish Forest Research Institute 79, pp. 9-13.

Skogsstyrelsen (2011): "Rutin - Identifiering av skogar med höga sociala värden." Skogsstyrelsen, Jönköping. 
"State of Europe's Forests 2011. Status and Trends in Sustainable Forest Management in Europe" (2011). Forest Europe, UNECE \& FAO. Available at: http://www.foresteurope. org/filestore/foresteurope/State_of_Europes_Forests_2011_Report/State_of_Europes_ Forests_2011_Report_Revised_November_2011.pdf. [Cited 22nd July 2013].

"Streamlining forest-related reporting" (2013). Collaborative Partnership on Forests. Available at: http://www.cpfweb.org/73035/en/. [Cited 16th August 2013].

"UK National Ecosystem Assessment" (2013). Available at: http://uknea.unepwcmc.org/. [Cited 23rd July 2013].

UNFF (2013): “United Nations Forum of Forests.” Istanbul 2013. Available at: http://www.un.org/esa/forests/index.html. [Cited 22nd July 2013].

UNWTO (2013): “World Tourism Organization. Tourism Highlights.” Edition 2012. Available at: http://www2.unwto.org/. [Cited 23rd July 2013].

Wiman, R. (1994). "The social dimension of Sustainable: Societies for All.” Dialog, English Supplement 4B, pp. 11-14. The National Research and Development Centre for Welfare and Health, Helsinki. 



\section{Appendix 1. Social indicators and monitoring in North European countries}

\subsection{Denmark Country Report}

Frank Søndergaard Jensen

\subsubsection{Introduction}

Research/monitoring of Danish forest recreation started in reality in 1975 with the Forest and Folk project, which conducted extensive surveys of the forest recreation activities and preferences of the general population. - A research project aimed at producing a better basis for decisions in the field of forest recreation. The surveys are published in four parts: Parts I, II, III and IV of Forest Recreation in Denmark (Koch 1978, Koch 1980, Koch 1984, Koch and Jensen 1988).

In the mid 1990s a new series of surveys was initiated - the Outdoor Life '95-'98 project. The major the aims of this project were: (1) to update the previous surveys of recreational forest use and preferences of the general population; (2) to analyze the trends between the 1970s and 1990s; and (3) to study new issues related to outdoor recreation - inclusive expansion of the area from only forest areas to cover the whole countryside. The surveys are published in three parts (Jensen and Koch 1997, Jensen 1998, Jensen 2003). In 2007/08 the third series of surveys (Outdoor Recreation 2009) was initiated (Jensen 2012, Jensen \& Tvedt 2012).

The Forest and Folk project developed methods for surveying the outdoor (forest) life of the Danish population. The surveys described under the first two sub-headings of Forest Monitoring Programmes below, are all based on these methods, to retain the best possible basis for comparisons between the results and thus analyze for trends. For overviews in English, see Jensen and Koch (2004), and for more details Jensen (1999).

Beside the specific forest recreation monitoring, a few other repeated data collections/monitoring programmes with some relevance for the forest and outdoor recreation sector are presented at the end of the country report. 


\subsubsection{Danish Forest Policy}

Numerous references to the importance of outdoor recreation are included in the Danish National Forest Programme (Ministry of Environment 2002). Below, excerpts with special emphasis on monitoring/statistics/research are reported:

"The linkage between forest research and forest policy processes is seen as particularly important for a sound development of the forest sector. This is well in accordance with proposals for action from IPF (58b(vii)) and IFF (96c). Furthermore, the resolutions from the Ministerial Conferences in Helsinki (1993) and Lisbon (1998) also establish that the European countries are obliged to improve and adapt the national forest monitoring programmes to the need for documentation of sustainable forest management operations. This will be put into practice through for instance:

- following and documenting the conditions and development trends in the forests

- documenting the multiple functions of the forests (wood production, forest health, biological diversity, outdoor recreation)

- $\quad$ substantiate that the established goals have been fulfilled." (p. 32).

"In the coming years, forest-related research will in particular be concentrated on:

- Environmental economics and environmental sociology

- Environment and health, including outdoor recreation (national monitoring);" (p. 33).

\subsubsection{Forest Monitoring Programmes}

\section{National household surveys of forest use patterns}

Three national household forest use surveys have been completed in Denmark: Part I from the Forest and Folk project in the mid-1970s (Koch 1978), the Outdoor Life '95-'98 project in the mid-1990s (Jensen \& Koch 1997) and Outdoor Recreation 2009 in 2007-08 (Jensen 2012).

Data were gathered by national postal questionnaire-based surveys using the exact same methodology and question formulation to be able to make sound comparisons and detect trends, each involving 2-3,000 people representing the adult Danish population. For representative purposes the mailing of the questionnaires was distributed over a period of one year (one portion each month). 
From the Civil Registration System (Ministry of the Interior) a systematic gross random sample was drawn, representing the adult Danish population, 15-77 years. The samples (and the collected responses) were controlled for representativity (age, gender and county).

The response percentage was $91.4 \%$ for the 1976/77-survey, $83.7 \%$ for the 1993/94-survey and 65.6 for the 2007/08-survey. (Up to three reminders was used, mailed after 2, 3 and 5 weeks).

Results (indicators) include e.g. numbers and duration of forest visits; travelling time, distance and mode to the forest, activities, group size and distance to nearest forest.

\section{Specific surveys of forest destination-areas}

What is the geographical variation in the intensity of forest recreational use in Denmark? To answer this question - and to give exact data for the manager of the specific forest area, an on-site methodology in Part II of the Forest and Folk project was initiated.

\section{Part II of the Forest and Folk project}

The yearly number of visitor hours and visits was estimated for 446 forest areas with a total area of 187,000 ha in 1976/77 (42\% of the total Danish forest area). Questionnaire results for the car-borne use regarding duration of stay, group size, activities, travelling time and distance to the forest were obtained as well. The basic data collection consisted of 28,652 instantaneous, manual counts of parked cars and the delivering of 44,846 questionnaires. The response percentage for the questionnaires was 53.7\% (impossible to use follow-ups). Nearly all state forests and numerous private forest properties participated voluntarily in the basic data collection. It is assumed that the more intensively used forests are over-represented in the investigation. Detailed instructions for the fieldwork were elaborated. The recording was carried out at 20 stratified randomly selected times and at 2 subjectively selected times at peak use. The stratification took the seasonally, weekly and daily variation into account.

Different models for the relationship between the instantaneous counts on each individual area and permanent automatic recording have been considered. (See the description of the permanent counting stations below). The relative simple multiple linear regression model was chosen. If the regression estimates was not significant, or if the regression estimates deviates significantly from the sample estimate, the sample estimate for the area in question has been used (based only on the 20 registrations at randomly selected times). Calculating the questionnaire results is only possible by sample estimates. 
The total number of visitor hours was estimated from 1) the number of car-borne visitor hours, 2) the questionnaire results regarding the carborne visitors' travelling distance distribution in each forest area, and 3) the relationship between the percentage of the Danish forest visitors who travel to the forest by car at a given travelling distance (from the national household forest use surveys described above). The total number visits were estimated from the average length of stay per visit (car-borne/noncar-borne ratios from the national household forest use surveys).

The results show a large variation in the intensity of use. In most counties it is found that some forests are used up to about a thousand times more intensively than others. In Koch (1980) detailed descriptions of the different methodological aspects are presented as well as the results.

\section{The Outdoor Life '95-'98 project}

As for the national use surveys, a need for updating the results for the specific forest areas was found. Due to this, the Outdoor Life '95-'98 project was initiated and a new data collection on a local basis was accomplished in 1996/97 (Jensen 2003).

The data collection in the Outdoor Life '95-'98 project follows the same outline as described above for Part II in the Forest and Folk project in 1976/77, although some extensions and limitations was introduced:

- Other nature areas than forests were included (e.g. beach areas).

- Instead of 446 forest areas divided into 1,419 sub-areas in 1976/77, the surveyed area in 1996/97 consisted of 592 forest/nature areas (of 2,159 sub-areas), with an area of approx. 201,000 ha (174,000 ha forests, $36 \%$ of the total forest area).

- A total of 85,673 questionnaires were delivered and $46.7 \%$ was returned.

- The questionnaire-based survey was extended to include e.g. aspects of crowding as well as use of and preferences for a number of visitor facilities.

- Due to economic constraints regression estimates were not performed - only sample estimates.

The comparison between the two surveys shows the same tendency as found in the national household surveys of the general public: An increase in the number of visits. The geographical variation in use intensity as described for the 1976/77 survey was more or less retained. 


\section{Permanent automatic counting stations}

Four permanent counting stations have been in use since 1976. These registrations have a two-fold aim:

- To form the basis for the specific area surveys described above, and

- To describe the time-dependent variation and the trends in the extent of the recreational use of selected locations.

The counting stations operate according to the "net count procedure." I.e. all cars entering and leaving an area (which is only served by a single road for cars) are counted individually, and the results are recorded frequently at the same time (every 15 minutes). If the counting is precise, the following variables can be determined:

- Number of cars present at an arbitrary time (difference between the summed up number of entering and leaving cars)

- Number of car visitor hours (with round-error depending on registration-interval)

- Number of car visits (directly from the separate in- and outgoing traffic)

- Mean length of stay per car visit (estimated from two last-mentioned variables).

The counting stations are still operating. The practical work of inspection and collecting the data is carried out in cooperation with the Danish Road Directorate. See Koch (1984) for detailed results of time dependent variations and trends in the car-borne recreational use of the four selected forest areas. Also detailed description of the methodology and discussion of counting errors are given.

\subsubsection{Social Indicators in Danish National Forest Inventories}

The Danish NFI was renewed in 2002 and includes measurements on a large number of variables related to forest resources (e.g. forest area, species, spatial and ownership distribution), forest production and forest biodiversity (Nord-Larsen et al. 2008). In 2006, the measurement scheme was expanded to include social indicators related to the recreational use of the Danish forests.

The NFI is a continuous sample-based inventory with partial replacement of sample plots based on a $2 \times 2 \mathrm{~km}$ grid covering the Danish land surface. At each grid intersection, a cluster of four circular plots (primary 
sampling unit, PSU) for measuring forest factors (e.g. wood volume) are placed in a 200 × $200 \mathrm{~m}$ grid. Each circular plot (secondary sampling unit, SSU) has a radius of 15 meters. The sample of field plots has been systematically divided into five non-overlapping, interpenetrating panels that are each measured in one year and constitute a systematic sample of the entire country. Hence all the plots are measured in a 5-year cycle. Based on analysis of aerial photos, each sample plot (SSU) is allocated to one of three basic categories, reflecting the likelihood of forest or other wooded land (OWL) cover in the plot: Unlikely to contain forest or other wooded land cover, Likely to contain forest, and Likely to contain other wooded land. All plots in the last two categories are inventoried in the field.

Based on a trial inventory in 2006, 11 social indicators were identified. The indicators were registered by the measurement crews as they were travelling along the edge of the $200 \times 200 \mathrm{~m}$ grid square of each cluster. The registrations were restricted to 1) physical features and indicators of the supply of goods related to the recreational use of the forest (i.e. hiking trails, camping facilities, fireplaces and other recreational facilities) and 2) the effects of the recreational use (i.e. littering or vandalism on trees) (Jensen et al. 2008, Johannsen et al. 2013). The indicators included are presented in Table 1.

After the trial inventory of social indicators in 2006, registration of social indicators became a permanent feature of the Danish NFI. Based on the experiences gathered during the trial inventory some features of the sampling scheme were changed in the subsequent permanent sampling scheme. 


\begin{tabular}{|c|c|c|c|}
\hline Main type & Indicator & Scale & Comment \\
\hline \multirow[t]{3}{*}{ Access } & Roads & Number & Number of times roads, tracks and \\
\hline & Tracks & Number & trails intercepts cluster edge \\
\hline & Trails & Number & \\
\hline \multirow[t]{4}{*}{ Facilities } & Hunting & Indicator $(0,1,2,3)$ & Indicator variables are related to \\
\hline & Camping & Indicator $(0,1,2,3)$ & the type of facilities for each of the \\
\hline & Fireplaces & Indicator $(0,1,2,3)$ & indicators. \\
\hline & Other facilities & Indicator $(0,1,2,3)$ & \\
\hline \multirow[t]{3}{*}{ Litter } & $\begin{array}{l}\text { Amount of litter related } \\
\text { to recreational use }\end{array}$ & Indicator $(0,1,2,3)$ & $\begin{array}{l}\text { Indicator variables are related to } \\
\text { the amount and type of litter for } \\
\text { each of the indicators }\end{array}$ \\
\hline & $\begin{array}{l}\text { Type of litter related to } \\
\text { recreational use }\end{array}$ & Indicator $(0,1,2,3,4,5)$ & \\
\hline & $\begin{array}{l}\text { Main type of litter not } \\
\text { related to recreational } \\
\text { use }\end{array}$ & Indicator $(0,1,2,3,4,5,6)$ & \\
\hline Vandalism & Vandalism & Indicator $(0,1,2,3)$ & $\begin{array}{l}\text { Indicator variable relates to the } \\
\text { subject of vandalism (trees or } \\
\text { facilities) }\end{array}$ \\
\hline
\end{tabular}

The first experience of this expansion of the traditional national forest inventories show that they can relatively simply and cost efficient be expanded to include a number of social indicators which is not available otherwise. The continuity of the measurements will be a valuable addition to sustainable knowledge-based management and policy decisions in relation to the social (recreational) aspects of forestry.

\subsubsection{Other Relevant Monitoring Programmes}

\section{Danish Culture and Leisure Surveys}

The so-called Danish Culture and Leisure Surveys have (mainly) been funded by the Ministry of Culture. The most recent survey is from 2012 and is a follow-up and update of the previous cultural practise studies which have been conducted in 1964, 1975, 1987, 1993, 1998 and 2004 (the first two years only including adults). The studies elucidate the population's (from seven years and up) current cultural habits and resultant changes over time from 1964, including changes in activity and consumption patterns as a result of new offers and activities. The study generally involves about 3,000 adults aged 15 years and about 1,000 children and adolescents aged 7-15 years (e.g. Fridberg 1989, 1994, 2000, Bille et al. 2005, Epinion \& Pluss Leadership 2012).

These surveys include a number of leisure indicators which is relevant to compare with indicators in relation to use of nature - e.g. time 
spend watching television, dvd and video; playing computer games; reading books and newspapers; number of visits at libraries, museums, concerts and theaters; and participation in sports and exercise.

In the most recent surveys, leisure activities like hiking, jogging, hunting and fishing is included, as well as walking cycling in the nature/neighborhood/to work. These indicators are of particular interest in a nature/forest context - although the latter is a good example of an indicator/variable which is not very precise as it combines numerous settings/reasons for the activity. Finally, it is worth mentioning, that some questions/indicators have been slightly changed over time, which makes comparisons over time uncertain for some aspects.

\section{Danish Sports and Exercise Practice}

As mentioned above, some sports and exercise activities have been included in the national culture and leisure surveys. These activities/indicators have been further developed in the sports and exercise surveys in 1998 and 2007 at the Danish Institute for Sports Studies (Pilgaard 2008, 2009). Beside numerous information in relation to specific sport activities, a number of indicators/questions relevant in a forest/leisure context are included, e.g.: Bicycling in nature areas, hiking in nature areas, hiking in urban parks, the importance of nature for sport and exercise and the influence of (easy) access to nature areas on sport and exercise activities. As mentioned for the culture and leisure surveys above, also here some questions/indicators have been slightly changed over time, which makes some comparisons over time uncertain.

\subsubsection{References}

Bille, T., Fridberg, T., Storgaard, S. and Wulff, E. (2005): "Danskernes kultur- og Fritidsaktiviteter 2004 - med udviklingslinjer tilbage til 1964." Socialforskningsinstituttet, København, 437 p.

Epinion \& Pluss Leadership (2012): “Danskernes kulturvaner 2012.” Epinion \& Pluss Leadership, København, 381 p.

Fridberg, T. (1989): “Danskerne og kulturen - de 16-74-åriges fritidsaktiviteter 1987 sammenlignet med 1975 og 1964." Socialforskningsinstituttet, København, 173 p.

Fridberg, T. (1994): “Kultur- og fritidsaktiviteter 1993." Socialforskningsinstituttet, København, 281 p.

Fridberg, T. (2000): “Kultur- og Fritidsaktiviteter 1975-1998." Socialforskningsinstituttet, København, 359 p.

Jensen, F. S. (1998): “Friluftsliv i det åbne land 1994/95." Forskningsserien nr. 251998, Forskningscentret for Skov \& Landskab, Hørsholm, 151 p.

- (1999): "Forest Recreation in Denmark from the 1970s to the 1990s." Forskningsserien nr. 26-1999, Forskningscentret for Skov \& Landskab, Hørsholm, 156 p. 
- (2003): "Friluftsliv i 592 skove og andre naturområder." Skovbrugsserien nr. 322003, Forskningscentret for Skov \& Landskab, Hørsholm, 335 p.

- (2012): “Friluftsliv i skovene 2008 (1).” Introduktion. Videnblade Planlægning og Friluftsliv nr. 6.1-64, Skov \& Landskab, Frederiksberg, 2 p.

- and Koch, N. E. (1997): “Friluftsliv i skovene 1976/77-1993/94." Forskningsserien nr. 20, Forskningscentret for Skov \& Landskab, København, 215 p.

- and Koch, N. E. (2004): "Twenty-five years of forest recreation research in Denmark and its influence on forest policy." Scand. J. For. Res. Vol. 19 Suppl. 4, pp. 93-104.

- and Tvedt, T. (2012): "Skovene på førstepladsen som mål for friluftsliv." Geografisk Orientering Vol. 42 No. 4, pp. 586-591.

Jensen, F. S., Skov-Petersen, H. and Johannsen, V. K. (2008): "Friluftslivstatistik: Strategi og manual 2008." Skov \& Landskab, Frederiksberg, 165 p.

Johannsen, V. K., Nord-Larsen, T., Riis-Nielsen, T., Suadicani, K. and Jørgensen, B. B. (2008): “Skove og plantager 2012." Skov \& Landskab, Frederiksberg, 189 p.

Koch, N. E. (1978): "Skovenes friluftsfunktion i Danmark. I. del. Befolkningens anvendelse af landets skove." [Forest Recreation in Denmark. Part I: The Use of the Country's Forests by the Population]. - Forstl. Forsøgsv. Danm., København, Vol. 35 (1978), pp. 285-451.

- (1980): "Skovenes friluftsfunktion i Danmark. II. del. Anvendelsen af skovene, regionalt betragtet." [Forest Recreation in Denmark. Part II: The Use of the Forests Considered Regionally]. - Forstl. Forsøgsv. Danm., København, Vol 37(1980), pp. 73-383.

- (1984): "Skovenes friluftsfunktion i Danmark. III. del. Anvendelsen af skovene, lokalt betragtet." [Forest Recreation in Denmark. Part III: The Use of the Forests Considered Locally]. - Forstl. Forsøgsv. Danm., København, Vol. 39(1984), pp. 121-362.

- and Jensen, F. S. (1988): "Skovenes friluftsfunktion i Danmark. IV. del. Befolkningens ønsker til skovenes og det åbne lands udformning." [Forest Recreation in Denmark. Part IV: The Preferences of the Population]. - Forstl. Forsøgsv. Danm., København, Vol. 41(1988), pp. 243-516.

Ministry of Environment (2002): “The Danish national forest programme in an international perspective." Danish Forest and Nature Agency, Copenhagen, 43 p. Available at: http://www.naturstyrelsen.dk/NR/rdonlyres/6BA78078-1188-494B841E-EF89ECF0C064/13461/dnf_eng.pdf. [Cited 29th July 2013].

Nord-Larsen, T., Johannsen, V. K., Jørgensen, B. B. and Bastrup-Birk, A. (2008): “Skove og plantager 2006." Skov \& Landskab, Hørsholm, 185 p.

Pilgaard, M. (2008): “Danskernes motions- og sportsvaner 2007.” Idrættens Analyseinstitut, København, 91 p.

Pilgaard, M. (2009): “Sport og motion i danskernes hverdag.” Idrættens Analyseinstitut, København, 374 p. 


\subsection{Estonia Country Report}

Anu Almik (State Forest Management Centre, Estonia), Kerli Karoles (State Forest Management Centre, Estonia) and Kalle Karoles (Estonian Environment Information Centre, Estonia)

\subsubsection{Introduction}

Forests are an essential part of Estonian landscape. More than half of the country is covered with forests, which account for about 2.2 million hectares of which about $40 \%$ is state owned. Estonians have always had a close relationship with their forests, and long traditions of forestry (Karoles and Valgepea 2012).

This report will give an overview of social indicators related to naturebased recreation and tourism in Estonia. It focuses on indicators used in national documents and on data that is collected by different agencies that could possibly be formulated and used to cover the need for information of social indicators. The report is presented in four sections:

- Indicators used according to international commitments

- Indicators presented in different national documents and databases

- Indicators used in different organizations

- Conclusions and development opportunities.

\subsubsection{Indicators used according to international commitments}

\section{Ministerial Conference on the Protection of Forests in Europe (MCPEF): Pan-European Indicators for Sustainable Forest Management (SFM)}

As an international commitment, Estonia is providing at a regularity of 5 years data for the Forest of Europe process report on "State of Forests and Sustainable Forest Management in Europe." The indicator $6.10 \mathrm{Ac}$ cessibility for recreation and intensity of use shows the area of forest and other wooded land where public has a right of access for recreational purposes and indication of intensity of use. The information concerning state forests and protected areas is gathered systematically but there is in Estonian conditions a lack of information concerning private forests.

Estonian forest and other wooded land areas have access available to the public for recreational purposes, because of "everyman's right". In State forests limitations apply mainly to strictly protected zones (re- 
serves) in protected areas. The amount of publicly accessible private forest land and also the intensity of use are difficult to measure. According the "everyman's right", the private forests should have access available to the public, but in fact there are some technical restrictions, for example if the private roads are not passable or pass residential lands etc. Sometimes, during the inflammable periods, the possibility to visit the forests can also be limited.

\subsubsection{Indicators presented in different national documents and databases}

\section{National Spatial Plan of Estonia, Estonia 2030}

In the National Spatial Plan of Estonia 2030 (Üleriigiline... 2012) the importance of preserving the good condition of the natural environment is emphasized. According to the National Spatial Plan of Estonia 2030 the structure, coherence and the amount of green structures in Estonia are good, but no indicators are presented. It is said that the size of the green network core areas shouldn't decrease more than $10 \%$.

\section{Nature Conservation Development Plan 2020}

One of the objectives of the Nature Conservation Development Plan 2020 (Looduskaitse... 2012) is raising the environmental awareness of the people through environmental education on all levels of education, development of nature conservation research, organization of sustainable environmental tourism. Essential activities in the field of use of natural resources are, for example, taking account of the value of the services of ecosystem.

Measurable indicators:

- Share of population who considers their behavior environmental aware.

- Amount of nature education programs used by school and kindergarten children.

- Amount of people participating in nature education programs.

- Amount of visits of nature trails.

To learn the opinion of Estonian residents on the state of the natural environment and their environmental awareness The Ministry of the Environment has ordered several surveys on the environmental awareness of Estonian population (Eesti elanike... 2012). The most recent ones were conducted in 2012, 2010 and 2008. 
The surveys showed that Estonian people generally consider themselves environmentally aware. Compared to the 2010 survey (Eesti elanike... 2012), the assessment on the environmental awareness of the society has risen. Outdoor recreation possibilities in nature offered by hiking and study trails are still popular. More than half of the respondents (61\%) have visited different nature trails in the last 12 months.

Estonian Environmental strategy 2030 and Estonian Environmental Action Plan 2007-2013

In the Estonian Environmental Strategy 2030 (Eesti keskkonnastrateegia... 2007) the objective of the forest sector is the balanced satisfaction of ecological, social, cultural and economic needs in the course of use of forests in a long perspective. Forests should offer economic benefits (timber, mushrooms, berries and other forest products) and also socio-cultural benefits like recreation, hiking possibilities and cultural-historical sites. At the same time, the diversity, balance and regeneration capacity of forest ecosystems must be preserved. Owing to the long term of the Strategy, the desired trends of changes were set as indicators rather than particular target levels. Data for 2005 was set out as the base level.

Main indicators related to forests:

- Forest area, expressed in hectares

- Area of forests protected as key biotopes

- Area of protected forests and protection forests, expressed in hectares

- Area of primeval forests by different forest types, expressed in hectares

- Investments (amount of money) appointed at recreation purposes in state forests.

In the section that deals with preservation of the diversity of landscapes and biodiversity the coherence of different landscape types is emphasized. In a broader meaning, coherent landscapes constitute networks (complexes of landscapes) whose composition includes ecologically functioning units of various structures, which ensure the existence of valuable habitats and the preservation of social and economic values.

The general directions and goals are set in Estonian Environmental strategy 2030 and activities are set in Estonian Environmental Action Plan 2007-2013 (Eesti keskkonnategevuskava... 2007). 


\section{Estonian National Strategy on Sustainable Development - Sustainable Estonia 21}

In the Estonian National Strategy on Sustainable Development - Sustainable Estonia 21 (Eesti säästva... 2005) there is the objective to increase the welfare of the population. Among the components of welfare is the variety of possibilities, including opportunities for recreation, but no measurable indicators are presented.

\section{Estonian National Tourism Development Plan 2007-2013}

According to the Estonian National Tourism Development Plan 20072013 (Eesti riiklik... 2006) the goal is that tourism related information is up to date and is easily available. To get feedback tourism related visitor surveys are conducted, although the tourism related information gathering methodology needs to be improved and harmonized and there is a need for a national database.

Tourism research and statistics are needed to adequately assess the role of tourism in the Estonian economy, the measures necessary for the development of the tourism sector to plan and evaluate their effectiveness. The improvement of tourism research and the development of a database could also benefit the measurement of indicators related to nature-based tourism.

\section{National health plan 2009-2020}

In the National health plan 2009-2020 (Rahvastiku... 2008) one chapter focuses on the main health risks and development of health behavior. The risk factors of diseases and injuries are often interlinked and, therefore, their prevention should be approached in a complex manner. Among other main behavioral health impact factors there is also featured limited physical activity.

To increase the physical activity of the population among other measures the following were mentioned:

- Providing an environment and infrastructure that supports physical activity.

- Regularly monitor and assess the exercise habits of the population, the impact factors that affect the level of exercising and the relevant interventions; update the database of sports statistics.

The database of sport statistics gives detailed information of different sport facilities and sport related organizations but does not provide information of nature-based recreation opportunities. 


\section{Estonian Forestry development plan 2020}

In the forestry development plan 2020 (Metsanduse... 2011) is stated that in addition to other obligations of the State Forest Management Centre of Estonia the task is to maintain the public functions like recreational services in state forests. According to the forestry development plan State Forest Management Centre has to have a development plan (See chapter 2.4.1.) to ensure that the organization's activities are in the best interest of the society.

\subsubsection{Indicators used in different organizations}

\section{Development Plan of State Forest Management Centre 2011-2014}

State Forest Management Centre (RMK) is the manager of state forests. One of the objectives of RMK is to offer outdoor recreational possibilities and introduce sites of protection value through the nature tourism system based on everyman's right in recreational and protected areas.

In addition to creating and planning recreation opportunities in RMK's recreation areas and protected areas, RMK is providing information about those opportunities and is organizing environmental education activity in RMK's nature centers and nature houses. In total there are 13 RMK recreation areas across Estonia and since February 2009, RMK is also dealing with visitor management in five national parks and in approximately 40 other protected areas.

In the RMK development plan (RMK... 2010) there are among other measurable parameters also indicators related to outdoor recreation. These indicators include:

- number of graduates of RMK's nature education programs

- number of different nature education programs

- number of forest visits in RMK recreational and protected areas

- number of people receiving information from RMK on gathering areas for berries and mushrooms

- customer satisfaction

- carrying capacity of ecosystems.

To provide information on those indicators different surveys are conducted. In 2008 RMK published the manual "Visitor monitoring in nature areas" (Kajala et al. 2007) in Estonian. RMK has been using onsite guided visitor survey method and automatic visitor counting methods described in the manual since 2002. In April 2009 RMK took into use a new application KÜSI for entering and processing the visitor information. The 
application which was specially developed for Metsähallitus from Finland the user interface was translated to Estonian and a few customizations were made to the application to meet the needs of RMK.

\section{Visitor surveys}

The visitor survey has been carried out on all recreational areas of RMK to establish the motivation, preferences and needs of visitors in recreational areas and to determine whether the developed facilities meet the expectations of the users. The visitor survey has been repeated in 2003, 2006 and 2010. Visitor surveys have been carried out at the same year on all recreational areas of RMK and on protected areas and they are carried out on the same basis.

Visitor surveys give a big variety of information, for instance:

- Amount of money used during the visit

- Visitor profile

- Length of the visit

- Recreation objects visited

- Main motives for visitation

- Main activities during the visit

- Visitor satisfaction

- Sources of information for the visit.

\section{Visitor counting}

Visitor counting is continuously conducted in all RMK recreational areas since 2002. In $2009 \mathrm{RMK}$ installed first counters also on protected areas. In 2012 there were hundred and thirty electronic counters installed in RMK recreational areas and protected areas. The installation of counters, taking counter readings, the maintenance, calibration of counters and extrapolating the point counting results is done as described in the manual "Visitor monitoring in nature areas."

\section{Nationwide recreation studies}

The primary objective of the study was to find out the level of awareness of the Estonian residents concerning the opportunities developed by RMK for the outdoor recreation activities and the level of the demand for and use of offered opportunities. The study has been conducted by the Survey Research Centre Faktum in 2003, 2006 and 2009. 
The results of the 2009 survey show that:

- $54 \%$ of Estonian population between the age of 15-74 have visited some of RMK's recreation areas or national parks in the last 12 months.

- $91 \%$ of the population find the recreation opportunities provided by RMK very important or rather important.

- The awareness of RMK recreation areas is high - $86 \%$ have heard about them.

\section{Study on the social carrying capacity of the population living close to recreation areas}

In 2006 RMK ordered from the Survey Research Centre Turu-uuringute AS a survey to find out the attitude of people living close to 5 most problematic recreation areas towards recreation opportunities provided by RMK.

According to the survey most people have a positive attitude towards the activities of RMK's recreation areas. The majority of respondents felt that recreation areas benefit the local municipality.

\section{Statistics Estonia}

The main task of Statistics Estonia is to provide the objective information service on economic, demographic, social and environmental situation and trends in Estonia. Official statistics is in compliance with international classifications and methods (Statistikaamet 2012). Among the collected information, there is little information found related to nature-based recreation, some may be found in the time use survey.

Statistics Estonia has conducted the time use survey twice - in 2000 and 2010. The time use survey provides a great variety of statistical data of people's use of time. Respondents record their activities in time diaries, using their own words. Time use is a good indicator of well-being (Statistikaamet 2012). There are comparable statistical tables on the organization and activities (incl. walking and hiking) of everyday life. Most of the national time use data shows average time spent on an activity. For instance how people spend their free time (incl. walking and hiking; hunting, fishing, mushrooming and picking berries).

Since there was comparable or almost comparable data representing a number of European countries, a database was put together. Currently the National Time Use Survey web application HETUS (Harmonized European... 2012) from 2000 contains information from fifteen European countries. 


\section{Surveys conducted by Enterprise Estonia (EAS)}

Enterprise Estonia has ordered a survey about domestic trips during the summertime among Estonian people (Ettevõtluse Arendamise Sihtasutus..., 2011). The survey has been conducted in 2005, 2006, 2007, 2008, 2009 and 2011. The 2011 survey, conducted by OÜ Eesti Uuringukeskus, gave for instance information about:

- amount of people who made domestic trips during the summer.

- amount of people who made one-day or overnight domestic trips, average time of the trip, destination etc.

- accommodation type (friends or family, summerhouse, tent, hotel or other accommodation type with a fee etc.).

\subsubsection{Conclusions and development opportunities related to social indicators nature-based recreation and tourism in Estonian context}

In many of the Estonian national documents the need for nature-base recreation and it's positive impacts are mentioned but measuring them is difficult or isn't done in a comprehensive way. Data related to naturebased recreation is being collected by a variety of different organizations, but the usage of data is often limited and the process of collecting the data hasn't been coordinated on a national level. Better coordinating of the collection and usage of data related to nature-based recreation and sectors related to it (tourism etc.) can have a multitude of benefits like costefficiency and the possibility to get more reliable and comparable data.

In addition the optimization of the data collection process could benefit further development directions:

- The positive impact and importance of nature-based recreation to health and well-being is seen in The National Health Plan 2009-2020, but at the moment there are no measurable indicators related to it. More reliable data related to nature-based recreation could serve as a good base for developing those indicators.

- Since nature-based recreation is according to RMK visitor numbers getting more popular in Estonia there is the need for integration of visitor monitoring data with ecological carrying capacity to provide better data for management of recreation areas. 
- Economic and social impacts of nature-based recreation (promotion of sustainable regional development - employment, investments, etc.) and conflicts between interest groups (local population, visitors, environmental NGO etc.) are becoming more important with the increase of the popularity of nature-based recreation and therefore need to be researched more.

\subsubsection{References}

"Eesti keskkonnastrateegia aastani 2030" (2007). [Estonian Environmental strategy 2030]. Ministry of the Environment. Available at: http://www.envir.ee/orb.aw/ class=file/action=preview/id=1101230/inglisekeelne.pdf. [Cited 15th August 2012].

“Eesti keskkonnategevuskava aastateks 2007-2013" (2007). [Estonian Environmental Action Plan 2007-2013]. Ministry of the Environment. Available at: http://www.envir.ee/orb.aw/class=file/action=preview/id=1101231/inglise_keel es_tegevuskava.pdf. [Cited 15th August 2012].

"Eesti riiklik turismi arengukava aastateks 2007-2013" (2006). [Estonian National Tourism Development Plan 2007-2013]. Riigi Teataja. Available at: https://www. riigiteataja.ee/akt/12755212. [Cited 15th August 2012].

"Eesti säästva arengu riiklik strateegia - Säästev Eesti 21" (2005). [Estonian National Strategy on Sustainable Development- Sustainable Estonia 21]. Available at: http:// www.envir.ee/orb.aw/class=file/action=preview/id=166311/SE21_eng_web.pdf

Ettevõtluse Arendamise Sihtasutus, OÜ Eesti Uuringukeskus 2011 (2011). "Aasta suviste sisereiside uuring" [Domestic trips during the summertime among Estonian people]. Uuringukokkuvõte. Availabel at: http://static1.visitestonia.com/docs/ 187113_sisereiside-uuring-2011-suvi.pdf. [Cited 1st December 2012].

"Harmonised European time use survey web application - HETUS" (2012). Available at: https://www.h2.scb.se/tus/tus/default.htm. [Cited 6th August 2012].

Kajala, L., Almik, A., Dahl, R., Dikšaitè, L, Erkkonen, J., Fredman, P., Jensen, F. Søndergaard, Karoles, K., Sievänen, T., Skov-Petersen, H., Vistad, O. I. and Wallsten, P. (2007): "Visitor monitoring in nature areas - a manual based on experiences from the Nordic and Baltic countries." TemaNord 2007:534.

Karoles, K. and Valgepea, M. (eds.) (2012): “Eesti Metsandus 2011.” [Estonian Forestry 2011]. Estonian Environment Information Centre. Available at: http://www. keskkonnainfo.ee/failid/forestry2011/EstonianForestry.swf. [Cited 1st December 2012].

"Eesti elanike keskkonnateadlikkus" (2012). [Environmental awareness among Estonian population]. Keskkonnaministeerium, Keskkonnainvesteeringute Keskus, Turu-uurignute AS 2012. Available at: http://www.envir.ee/orb.aw/class=file/ action=preview/id=1187006/Eesti+elanike+keskkonnateadlikkus2012aruanne. pdf [Cited 15th August 2012].

"Looduskaitse arengukava aastani 2020" (2012). [Nature Protection Development plan 2020]. Keskkonnaministeerium. Available at: http://www.envir.ee/orb.aw/ class=file/action=preview/id=1186984/LAK_lop.pdf. [Cited 15th August 2012].

“Metsanduse arengukava aastani 2020" (2011). [Estonian Forestry development plan 2020]. Riigi Teataja. Available at: https://www.riigiteataja.ee/aktilisa/3180/ 2201/1003/Eesti_\%20metsanduse_arengukava.pdf. [Cited 15th August 2012]. 
“Rahvastiku tervise arengukava 2009-2020" (2008). [National Health Plan 20092020]. Ministry of Social Affairs. Available at: http://www.sm.ee/fileadmin/meedia/ Dokumendid/ASO/RTA/National_Health_Plan_2009_2020.pdf. [Cited 15th August 2012].

"RMK arengukava 2011-2014" (2010). [Development Plan of State Forest Management Centre 2011-2014]. State Forest Management Centre. Available at: http:// www.rmk.ee/files/RMK_Arengukava_ENG_20110622.pdf. [Cited 15th August 2012].

"Statistikaamet" (2012). [Statistics Estonia]. Available at: http://www.stat.ee/sotsiaalelu [Cited 6th August 2012].

“Üleriigiline planeering Eesti 2030+" (2012). [National Spatial Plan of Estonia $2030+]$. Available at: http://eesti2030.files.wordpress.com/2012/09/eesti-2030tekst_120725.pdf. [Cited 15th November 2012].

\subsection{Finland Country Report}

Tuija Sievänen, Liisa Kajala and Marjo Neuvonen

\subsubsection{Governmental programs and other policy documents}

\section{Finnish Forest Policy Programme and reporting Sustainable Forest Management}

In Finland, the governmental programs for forest policy, the National Forest Programs (NFP) 2010 and 2015, include a number of actions, of which some actions concern forest and nature-based recreation. A set of qualitative and quantitative indicators have been developed to monitor the implementation of the actions and their impacts on society and use of forest resources. These indicators are presented and discussed later in the article (chapter 2).

Finland has its own process for monitoring Sustainable Forest Management policy. Monitoring reports have been published since 1997 four times (Suomen metsätalouden tila 1997, 2000, State of Finland's Forests 2007, 2011). The FOREST EUROPE (The Ministerial Conference on Protected Forests in Europe) indicators have been partly applied in this process but they are complemented by some national indicators. Finland has also Strategy for Natural Resources (Kansallinen luonnonvarastrategia... 2009), which pay attention to the possibilities to gain wellbeing from recreation in nature. The Strategy for Protection of Biodiversity and Sustainable Use (2007) also recognizes the need for integration of nature-based tourism and nature conservation, because of the increasing interest for tourism in protected areas, and also because recreation in nature develops the awareness and appreciation of nature among population. 


\section{Nature-based recreation and tourism development program (VILMAT) and Tourism strategy}

Finland has had a development program for nature-based recreation and tourism (Ohjelma luonnon ...2002 - VILMAT report), which was made by the Ministry of Environment. It includes 30 different actions covering administrative structures related to recreation, policy of managing state-owned land and water areas for recreation and tourism, policy for regional and municipality level cooperation and policy for recreation research. The VILMAT program did not include indicators for monitoring its actions. VILMAT-report gave a definition for nature-based recreation and tourism, which is now widely used. Nature-based recreation and tourism means actions and activities, which are based on use of nature and all kinds of natural resources for recreational purposes.

One benchmark of policy documents concerning nature-based recreation is a guidebook for use of everyman's rights, which collects the guidance of legislation and examples of good practice into written form for the first time. The publication is published by Ministry of Environment (Tuunanen et al. 2012).

Finland's Tourism Strategy (Suomen matkailustrategia 2020, 2011) was updated in 2011, and it includes also documents reviewing the state of art of tourism research (Honkanen and Komppula 2009) and development plan for tourism research (Suomen matkailun tutkimuksen... 2011). In the last document, developing better statistics for tourism is one of the suggested actions, including a need for monitoring and indicators. The strategy does not include any examples of what kind indicators are needed. Any of these national, governmental documents related to recreation and tourism do not include monitoring or evaluation processes, which would make use of or be based on indicators.

\subsubsection{Social indicators related to Forestry and Sustainable Forest Management}

\section{Development of recreation indicators for National Forest Program}

Ministry of Agriculture and Forestry paid an attention to the shortage of suitable social indicators for the nature-based recreation and tourism for monitoring related actions in National Forest Program (NFP). An expert panel of nature-based recreation and tourism and forest related cultural values was invited to deliver suggestions and recommendations to the NFP process. A document of national and international literature review, which included also the indicators of FOREST EUROPE reports (Huhtala et al. 2007) created starting point for the expert panel work. 
The workshop of experts had three sessions during the spring 2009, and 28 experts participated. The work was organized in three working groups, of which one was focusing on nature-based recreation issues, one on nature-based tourism and one on cultural issues (Sievänen 2010). The recommendations based on this workshop effort were applied in the NFP assessment report in 2009 and they continue to be applied also in the future assessments of the NFP.

The nature-based recreation working group discussed the different aspects of qualitative criteria, nature and purpose of the indicators, which are needed for monitoring the impacts of policy actions on national level. Two different levels of indicators were found to be needed. First, there is a need to have indicators to monitor changes in the field of nature-based recreation in general (related to society wide or sector wide development), which are able to describe the general development and changes concerning nature-based recreation or recreational use of forests as a way of using forest resources. Second, there is a need to have indicators to monitor objectives achieved, impacts and changes caused by a special policy, an action program, a plan or a single action: direct or indirect impact or change, which is a result of administrative, legislative or financial actions, investments or other types of actions directed to recreational use of forest resources. Next, the status of importance or applicability of an indicator was to be assessed, and three categories were identified: 1) geographical importance: international, country wide, regional; 2) sector/policy wide; and 3) action specific impact.

In the process aiming to identifying the suitable indicators for monitoring policy impacts of NFP, a systematic approach was applied. All possible indicators explored from literature or identified by expert knowledge and experience were described by seven categories of information. The categories in which information was gathered and classified for each suggested indicator were: 1) status of importance or applicability, 2) the focus, issue or content of indicator, 3) measurement unit, 4) description of value/s of the measurement units, 5) description or information of the frequency of measurements and the history of past measurements, 6) the possible producer or provider of the information, and 7) others aspects/problems/future perspectives, and if used in another sector.

The workshop process produced 27 nature-based recreation indicators in three categories of which the first category "Society wide importance and status of everyman's rights" includes 5 indicators, the category "Demand for forest/outdoor recreation" has 12 indicators, and the category "Supply of recreation opportunities" has 10 indicators. In table 1 , suggested indicators for nature-based recreation are presented. 


\begin{tabular}{|c|c|}
\hline & Indicator \\
\hline \multirow{5}{*}{$\begin{array}{l}\text { "Society wide im- } \\
\text { portance and status of } \\
\text { everyman's rights" }\end{array}$} & Awareness of everyman's right among population \\
\hline & Investments in recreation services by public sector \\
\hline & Index of balance between demand and supply of outdoor recreation opportunities \\
\hline & Number of members in outdoor recreation associations \\
\hline & Index of wellbeing effects of outdoor recreation \\
\hline \multirow[t]{12}{*}{$\begin{array}{l}\text { "Demand for forest/ } \\
\text { outdoor recreation" }\end{array}$} & $\begin{array}{l}\text { Participation rates of (\%) and frequency of participation in outdoor recreation } \\
\text { activities, and time used for recreation by population groups }\end{array}$ \\
\hline & $\begin{array}{l}\text { Participation rates }(\%) \text { and frequency of participation for forest related recreation } \\
\text { activities (berry picking, forest work in leisure time etc.) }\end{array}$ \\
\hline & Number of visits/1000 inhabitants per year and area (ha) \\
\hline & Satisfaction to recreation services by population groups \\
\hline & $\begin{array}{l}\text { Number of recreation activity occasions to privately owned land; separately } \\
\text { different outdoor activities such as berry picking, mountain biking, geocaching }\end{array}$ \\
\hline & Participation in forest work in leisure time in own forest; classified in types of work \\
\hline & $\begin{array}{l}\text { Recreational use of privately owned land; portion of outdoor recreation visits } \\
\text { compared to all recreational visits to close-to-home nature }\end{array}$ \\
\hline & Number of hunters based on the number of given hunting licenses \\
\hline & Number of hunters on state owned land based on given hunting permissions \\
\hline & $\begin{array}{l}\text { Change of number of hunters according to municipality inhabitant's hunting right } \\
\text { on state owned land }\end{array}$ \\
\hline & Number of visits in national parks and state-owned hiking areas per year \\
\hline & Number days used for nature-based tourism per year \\
\hline \multirow[t]{5}{*}{$\begin{array}{l}\text { "Supply of recreation } \\
\text { opportunities" }\end{array}$} & $\begin{array}{l}\text { Accessibility in terms of the number and area (ha) of recreation sites, and the } \\
\text { average distance from residence; incl. public transportation possibility }\end{array}$ \\
\hline & $\begin{array}{l}\text { Number recreation areas and trails in urban areas and in country side in whole } \\
\text { country/region/municipality }\end{array}$ \\
\hline & $\begin{array}{l}\text { Number or portion of inhabitants having land suitable for recreation in a distance } \\
\text { max } 300 \mathrm{~m} \text { from residence }\end{array}$ \\
\hline & $\begin{array}{l}\text { Number or portion of inhabitants having recreation area of size of } 100-200 \text { ha in a } \\
\text { distance max } 10 \mathrm{~km} \text { from residence }\end{array}$ \\
\hline & $\begin{array}{l}\text { Amount of inhabitants in urban municipalities in relation to amount of recreation } \\
\text { areas in the region }\end{array}$ \\
\hline
\end{tabular}




\begin{tabular}{l}
\hline $\begin{array}{l}\text { Indicator } \\
\text { Number and length of hiking/skiing trails by whole country/ region/ municipality/ } \\
\text { inhabitant }\end{array}$ \\
$\begin{array}{l}\text { Number and length of hiking/skiing trails in national parks and state-owned hiking } \\
\text { areas }\end{array}$ \\
Number and length of hiking/skiing trails on forested land in urban municipalities \\
Number of agreements of managed trails on privately owned lands between trail \\
management agency (municipality) and landowner \\
Number of national parks and state owned hiking areas \\
\end{tabular}

The two indicators, which were finally recommended to be applied in the monitoring of the policy of NFP were called "Outdoor recreation demand on population level" described by the frequency of annual visits (number of days used for recreation) and "Recreational opportunities" measured by number and length of hiking/skiing trails in whole country. For these two indicators, there was quantitative and up-to-date data available at the national level. Almost all the other indicators were lacking some consistency of data or there had been some costly data processing needed in order to provide the indicator with a short notice.

\subsubsection{Monitoring and reporting of nature-based recreation indicators}

\section{Monitoring on a national level}

National outdoor recreation demand inventory (LVVI) study provides Outdoor Recreation Statistics, which include measurements of a number of different aspects of outdoor recreation and nature tourism demand (see: http://www.metla.fi/metinfo/monikaytto/lvvi/index-en.htm). Measurements include overall participation in nature-based recreation and tourism, participation in 86 different outdoor activities and number of occasions per year, information of recreational occasions and nature trips, and some information resources for recreation (amount of free time, ownership of equipment and skills). LVVI can serve as a basis for recreation indicators. LVVI-studies are made by Finnish Forest Research Institute and they have been conducted twice: years 2000 and 2010.

There are two national level databases for recreation supply in Finland. The first is a database of sport services and facilities (LIPAS, maintained by University of Jyväskylä), and the second is the VIRGIS database (maintained by Environment Institute; available through Environmental 
database OIVA). Both databases provide information on recreation supply, e.g. recreation areas, services and facilities in natural areas. In principle, the databases are updated continuously, but in practice both databases have a lot of shortage of data. The problem is that the providers of the information are municipalities, and the keeper of database has no mandate to request information if the municipality does not provide it. The same problem applies to updating the content of the databases.

\section{Monitoring across protected areas on a national level}

Metsähallitus, Natural Heritage Services (NHS) manages all the national parks and the other state-owned protected areas, wilderness areas, national hiking areas and public waters in Finland. Since year 2000, Metsähallitus has been using a standardized method, developed together with the Finnish Forest Research Institute, to gather visitor monitoring data from those state-owned protected and recreational areas where recreation and tourism plays a significant role all across the country (Kajala et al. 2007). The monitoring consists of continuous visitor counting with electronic counters and of visitor surveys repeated at a five year interval.

The visitor monitoring data is primarily gathered for management and monitoring purposes and reports are produced by Metsähallitus NHS at national, regional and on-site levels. The visitor monitoring data gathered continuously in a uniform manner across the country and saved in one database (ASTA) provides opportunities for index such as local economic impacts of visitors' spending (Huhtala et al. 2010). These economic impacts have been calculated annually starting year 2009 using methodology devised by NHS and the Finnish Forest Research Institute. These economic calculations and reporting are integrated into the ASTA database.

The supply of recreation services (cabins, shelters, campfire-sites, hiking routes etc.) on state-owned protected and recreational areas is managed in a GIS database system called Reiska, which has been in use since year 2004. This system allows for national, regional and local statistics as well as cartographic analyses of the services at any level. The spatial data produced by Reiska GIS is also available through various internet and mobile location and cartographic applications designed for public use, including an internet map service launched by Metsähallitus in 2007 (excursionmap.fi). 


\section{National Forest Program and State of Finland Forests}

National Forest Program 2015, Monitoring of actions report includes following indicators.

- The total number of visits in national parks, national hiking areas and recreational forests was 4,848,700 in total in 2010. Number of visits in national parks was 1,958,500 and in state owned hiking areas 364,000.

- Metsähallitus (The Finnish Forest and Park Service) maintains about 6,700 kilometres of hiking and nature trails and 2,200 km of skiing trails.

- Nature tourism has remarkable regional economic impacts in communities surrounding national parks and other recreational areas. The economic impact estimate for national parks (35 parks) was 108.9 mill. Euros in total, and the employment impact was 1,403 person years, and respectively for state-owned hiking areas ( 7 areas) EUR 15.5 mill. and 201 person years.

State of Finland's Forests 2011 reports the state of sustainable forest management using both qualitative and quantitative indicators, which are partly adopted from FOREST EUROPE report. Accessibility of recreation services (FOREST EUROPE 6.10) is described with four indicators:

- A table of figures of recreation demand quoted from Outdoor Recreation Statistics (produced by Finnish Forest Research Institute Metla) "Participation in outdoor recreation activities in Finland, in 1998-2000 and 2009, described by participation rate changes and changes in participation frequencies."

- "Everyman's Rights are part of the Finnish way of life and leisure time. Movement in forests is only restricted in military areas and strictly protected nature reserves, where access requires a permit. Strict nature reserves are principally closed to the public, although some of them have marked paths for public access. Restrictions to free access apply to about $0.4 \%$ of the area of forestry land in Finland."

- About half of all outdoor recreation excursions in forests occur on privately owned land. Two fifths occur in local municipal recreation areas, which are important particularly for the residents of large cities and other built-up areas. One fifth occurs on state lands.

- Finns own 485,000 leisure homes in Finland, most of them in a forest and along a waterway. Leisure homes are popular: in $2009,64 \%$ of the population spent time at a leisure home, and the average number of visits per year was 38 . 


\subsubsection{The "status" of social indicators, monitoring and reporting}

In Finland, social indicators are part of the monitoring of sustainable forest management and also part of the monitoring of the state of actions written in National Forest Program 2015.

Social indicators including those related to nature-based recreation and tourism are assessed to have significant problems because of the lack of continuity and missing statistics. National outdoor recreation demand inventory (LVVI) study and its main product Outdoor Recreation Statistics could serve as a basis for recreation indicators, but the LVVI inventory is conducted only once in ten years and thus does not provide measurements for short term indicators.

Municipalities, which are responsible for the most part of recreational services to citizens, do not monitor recreational use of their parks and recreational areas. Likewise, supply information including land and water areas, recreational services and facilities are not gathered systematically in municipalities. In principle the two databases LIPAS and VIRGIS could be good sources of supply information if they were developed to cover all municipality recreation areas and services, privately owned recreation services and also recreational areas and services on stateowned areas. Currently, these databases are not systematically updated to an extent that they would cover recreation supply information across the whole country. In conclusion, at the moment, demand and supply information which cover geographically identical units is available only from state-owned areas as described in chapter 3.3.2.

Concerning nature-based tourism, lack of suitable statistics limits the use of the nature-based recreation indicators in tourism sector. However, some regional indicators are provided for decision making. For example, "Regional council of Lapland" provides statistics about tourism in Lapland (Tourism facts in Lapland - Statistical review 2011). Information of nature tourism indicators varies a lot according to the regions and local authorities. Data is often fragmental and it is not gathered systematically (Lehtimäki, Sievänen, Neuvonen 2008). 


\subsubsection{References}

Honkanen, A. and Komppula, R. (2009): "Matkailututkimuksen tila ja tulevaisuus Suomessa."

Selvitys valtakunnallisen matkailun tutkimusstrategian taustaksi." [Tourism research - status and future in Finland. Background report for the tourism strategy work]. University of Joensuu. Matkailualan opetus-ja tutkimuslaitos. Available at: http://www.tem.fi/index.phtml?s=2548 [Cited 11th September 2012].

Huhtala, M., Hytönen, M., Sievänen, T. and Wallenius, P. (2007): "Metsäsektorin sosiaalisen kestävyyden mittarit - taustaselvitys." [Review of social indicators of sustainable forest management]. Working Papers of the Finnish Forest Research Institute $44,87 \mathrm{p}$.

Huhtala, M., Kajala, L. and Vatanen, E. (2010): “Local economic impacts of national park visitors' spending in Finland: The development process of an estimation method." Metlan työraportteja / Working papers of the Finnish Forest Research Institute 149. Available at: http://www.metla.fi/julkaisut/workingpapers/2010/ index-en.htm. [Cited 29th July 2013].

Kajala, L., Almik, A., Dahl, R., Dikšaitė, L, Erkkonen, J., Fredman, P., Jensen, F. Søndergaard, Karoles, K., Sievänen, T., Skov-Petersen, H., Vistad, O. I. and Wallsten, P.

(2007): "Visitor monitoring in nature areas - a manual based on experiences from the Nordic and Baltic countries." TemaNord 2007:534. ISBN 91-620-1258-4.

"Kansallinen luonnonvarastrategia: Älykkäästi luonnon voimin" (2009). Sitra 2009. [Natural Resources Strategy. An opportunity for change] Available at: http://www.sitra. fi/julkaisut/muut/Kansallinen\%20luonnonvarastrategia.pdf [Cited 29th July 2013].

"Kansallinen metsäohjelma 2015 - Metsäalasta biotalouden vastuullinen edelläkävijä." [National Forest Programme 2015]. Available at: http://www.mmm. fi/fi/index/etusivu/metsat/kmo.html [Cited 3rd September 2013].

"Lapin matkailutilastollinen vuosikirja 2011." [Tourism facts in Lapland - Statistical review 2011]. Lapin liitto. Available at: http://www.lapinliitto.fi/c/document_ library/get_file?folderId=20782\&name=DLFE-11816.pdf. [Cited 30th October 2012].

Lehtimäki, J., Sievänen, T. and Neuvonen, M. (2008): "Luontomatkailun tilastojen kehittämistarpeet - taustaselvitys." Metsäntutkimuslaitos. Moniste, 75 p.

"Luonnon puolesta - ihmisen hyväksi. Suomen luonnon monimuotoisuuden suojelun ja kestävän käytön strategia 2006-2016” (2007). [Strategy for protection of biodiversity and sustainable use]. Suomen luonnon monimuotoisuuden suojelun ja kestävän käytön toimintaohjelma 2006-2016. Ympäristöministeriö. Suomen ympäristö 35/2007. Helsinki 2007.

“Ohjelma luonnon virkistyskäytön ja luontomatkailun kehittämiseksi (VILMATohjelma)" (2002). [Programme for developing recreation in the wild and nature tourism]. Suomen ympäristö [The Finnish Environment ] 535, 48 p.

Sievänen, T. (ed.) (2010): “Luontomatkailun, luonnontuotealan, virkistyskäytön ja metsäkulttuurin seurantamittarit." [Indicators for nature tourism, non-wood forest products, recreation and forest culture]. Working Papers of the Finnish Forest Research Institute 152, 55 p.

“State of Finland's Forests 2007. Based on the Criteria and Indicatorsof Sustainable Forest Management." Ministry of Agriculture and Forestry 7a/2007, 99 p. Available at: http://www.mmm.fi/en/index/frontpage/forests/sustainable_forest_ management.html [Cited 3rd September 2013]. 
"State of Finland's Forests 2011. Based on the Criteria and Indicatorsof Sustainable Forest Management." Ministry of Agriculture and Forestry 5a/2011. 96 s. Available at: http://www.mmm.fi/en/index/frontpage/forests/sustainable_forest_ management.html [Cited 3rd September 2013].

"Suomen matkailustrategia 2020" (2011). [Finland's tourism strategy 2020]. Ministry of Employment and Economy. Available at: http://www.tem.fi/?s=2548 [Cited 11th September 2012].

"Suomen matkailun tutkimuksen toimintaohjelma vuosille 2011-2020" (2011). [Tourism research development program in 2011-2020]. Ministry of Employment and Economy. Available at: http://www.tem.fi/?s=2845 [Cited 11th September 2012].

Tuunanen, P, Rautiainen, A. and Tarasti, M. (eds.) (2012): Jokamiehenoikeudet ja toimiminen toisen alueella. Lainsäädäntöä ja hyviä käytäntöjä. Suomen ympäristö 30. Ministry of the Environment, $144 \mathrm{p}$.

\title{
6.4 Northern Germany Country Report
}

\author{
Peter Elsasser and Priska Weller, Thünen Institute of Forest Economics
}

Traditionally the German population has a very emotional connection to German forests and their natural state (Lehmann 2001). Nowadays the right to access forests for recreation purposes is granted to the general population and this right is widely used as $75 \%$ of the population visit forests at least once per year. According to a study about nature awareness 2011 (Studie Naturbewusstsein 2011) the German population finds nature protection and biodiversity important and is willing to support respective initiatives. Nevertheless official promotion schemes for nature-based recreation are few and research about related social indicators is not very common.

The general and legal situation of forests and forest-based recreation in Germany is described by the following characteristics. In Germany 11 million hectares are covered by forests, this is about one third of the total area. Forests are divided between 3 different groups of owners: State forest (33\%), communal forest (23\%) and private forest (44\%). State forests are predominantly owned by federal states. The federal republic owns less than $4 \%$ of the forest area.

\subsubsection{Legal regulations}

Forest related issues are governed by the federal forests act (Bundeswaldgesetz), the federal hunting act (Bundesjagdgesetz) and the federal nature conservation act (Bundesnaturschutzgesetz). They are designed to protect forests and their diverse ecosystem functions including recreation, 
to promote and support the forestry sector and to regulate hunting and nature protection. German federalism and the resulting division of powers assign power of legislation in forestry to the German federal states. They set up states forests and nature protection acts (Landeswaldgesetze, Landesnaturschutzgesetze), which govern forest management on state level. State legislation may differ from federal legislation.

The federal forests act enforces the right of people to access forests for recreation purposes ( $\$ 14$ Bundeswaldgesetz). In this context recreation includes activities like riding bikes and horses, however hunting is not included. Within the frames of the forests act every owner of forest area can manage his forests however he wants, nevertheless population's right to access forests for recreation cannot be restricted (not considering various exceptions like afforestation areas).

\subsubsection{Indicators of forest recreation in Germany}

Several national and federal policy documents as well as national statistics documents were screened for social indicators regarding forestbased recreation.

Due to German federalism and the resulting state level organisation of forest management, federal policy documents do not govern forest management practically. Still policy documents discuss policy aims. The Forest Report 2009 (Waldbericht der Bundesregierung 2009) of the German federal government indicates costs and benefits, particularly regarding the provision of protection and recreation functions as well as non-timber goods in forests. Here the value of forest-based recreation is reported to be about EUR 50 per person per year and this economic value is used as an indicator. A Thuenen-work report (Küppers 2008. Arbeitsbericht: Belastungen der Forstbetriebe aus der Schutz- und Erholungsfunktion des Waldes) states cost to forest enterprises arising from the provision of protection and recreation functions of forests. These costs include increased expenditures, but also reductions in income of forest owners. On average these costs are not very high (i.e. about EUR 20 per hectare timber production area), however in individual cases they can be substantial.

Also the Sustainability Strategy 2002 (Nachhaltigkeitsstrategie 2002) and the Forest Strategy 2020 (Waldstrategie 2020, 2011) both specifically mention access to forests and its meaning for the welfare of the population. Furthermore the National Forest Programme (Nationales Waldprogramm) promotes the sustainable management of forests and the Biodiversity Strategy (Biodiversitätsstrategie) monitors the natural condition of forests. These policy documents concentrate on general 
statements regarding access, protection of the living environment and forest biodiversity, but indicators are not systematically monitored.

National statistics concentrate on measurable physical units like the area (hectare, square kilometres) which is accessible for the general population. The Federal Statistical Office (Statistisches Bundesamt) also publishes information about areas available for recreation, not only in forests. In the Federal Test Enterprise Network (Testbetriebnetz) some forest areas are defined as recreation forests and sizes of respective forests are summed up. This procedure has been changed, now mainly nature protection forest areas are included. The German Integrated Environmental and Economic Account (Umweltökonomische Gesamtrechnung) and the Forest Account (Waldgesamtrechnung) do not publish data regarding recreation values.

Hunting is not considered as recreation and thus not valued in recreation contexts. Economically hunting does play a role in national statistics. Here hunting is estimated through the value of game meat, not so much through the value of hunting licenses or its recreation value. In Germany about 350,000 people own a hunting license.

On state level forest managers collect additional data which are not published regularly. Some of them (e.g. intensity of use, head count or estimation of number of forest visitors, partly done at the Thuenen Institute) however are reported to Forest Europe, to contribute to Forest Europe reports. These information include a valuation of forest services (Indicator 3.4), as well as areas accessible for public recreation (Indicator 6.10) and cultural and spiritual sites (Indicator 6.11).

As mentioned before, free access for the purpose of recreation is guaranteed to the population in most German forests, even private forests. This is due to the multi-functionality approach (Multifunktionenansatz), which is followed in several German states. This approach acknowledges that forest areas can be assigned to one or more functions which they provide. This includes physically usable functions, but also consideration of protection and recreation functions. Where different areas are assigned to one or more functions (including recreation) costs arising from the respective function (e.g. building of benches) can be allocated accordingly. Forest authorities are not only responsible for gathering respective data and mapping them but also for promotion of multi-functional forests. This is mostly for planning and monitoring purposes.

Since 2013 the new Forest Climate Fund (Waldklimafonds) is available to co-finance measures for adaptation to and mitigation of climate change in forests with a special focus on nature protection. These measures might also influence recreation or its indicators. 
Additional literature deals with further aspects of forest-based recreation.

Protection is still mostly voluntary, and often certified by FSC and PEFC. 7\% of German forest areas are certified according to FSC criteria, $65 \%$ of German forest areas are certified according to PEFC criteria. FSC and PEFC are internationally acknowledged NGOs which certify forests also in Germany, according to nationally defined principles and criteria. They include natural and socio-economic criteria (e.g. the right to access forests for recreation or fostering cultural traditions, or management of forests with regards to non-timber products).

Despite the limited governmental monitoring schemes the German population is interested in recreation in forests and substantial willingness to pay (WTP) for this exists. Several case studies and nationwide surveys conducted by the Thuenen Institute and others prove that forestbased recreation is valued and appreciated by the general population.

\subsubsection{Monetary valuation}

Many goods (provided by forests) are valued on the market, however, goods not sold on markets have to be valued using other methods. Recently a study about economic valuation of non-market goods provided by forests (e.g. the possibilities for recreation for the general public) was conducted by the Thuenen Institute (Elsasser \& Weller 2013). In the study actual willingness to pay values for forest-based recreation are presented, elicited in a nationwide contingent valuation survey. These WTP values are compared to 1992-values of another Thuenen-study, which is also cited in national policy documents (Elsasser 1996). Intertemporal comparison revealed that since 1992 WTP has decreased from about 50 EUR per person per year to about 30 EUR per person per year, aggregated values decreased from 2.5 Bn. EUR per year to $1.7 \mathrm{Bn}$. EUR per year (all nominal values). Thus willingness to pay for forest-based recreation exists. Regional differences in willingness to pay also became visible in this study. Furthermore, results indicated that additional willingness to pay for changes in forest composition is limited (about 1 EUR per person per year). So overall the German population is satisfied with forests as they are. Separate willingness to pay for nature protection has been elicited in other studies.

Nowadays more people than 1992 visit German forests (75\% of German population) and use available recreation facilities (e.g. benches). However forest visitors not only enjoy walking and hiking for recreation purposes, but also sports off track, like mountain biking and geocaching 
(outdoor activity where by using GPS devices containers/caches are to be found). Locally, these activities do lead to conflicts between recreationists and forest managers requesting compensation, as these activities might damage timber production.

\subsubsection{References}

"Biodiversitätsstrategie 2007." [Biodiversity Strategy]. Federal Ministry for the Environment, Nature Conservation and Nuclear Safety.

"Bundesjagdgesetz." [Federal hunting act].

"Bundesnaturschutzgesetz." [Federal nature conservation act].

"Bundeswaldgesetz." [Federal forests act].

Elsasser, P. (1996): “Der Erholungswert des Waldes. Monetäre Bewertung der Erholungsleistung ausgewählter Wälder in Deutschland." Sauerländer's.

Elsasser, P. and Weller, P. (2013): "Aktuelle und potentielle Erholungsleistung der Wälder in Deutschland." Allgemeine Forst- und Jagd-Zeitung Vol. 184 No. 3+4.

Küppers, D. and Dieter, M. (2008): "Thuenen work report: Belastungen der Forstbetriebe aus der Schutz- und Erholungsfunktion des Waldes."

"Landeswaldgesetze." [States forests acts].

Lehmann, Albrecht (2001): "Mythos deutscher Wald. In: Landeszentrale für politische Bildung Baden-Württemberg (Hrsg.):" Der deutsche Wald. 51. Jahrgang Heft 1 (2001) Der Bürger im Staat, pp. 4-9.

"Nachhaltigkeitsstrategie 2002." [Sustainability Strategy]. Federal Government.

"Nationales Waldprogramm." [National Forest Programme].

"State of Europe's Forests 2011." Forest Europe.

"Statistisches Bundesamt." [Federal Statistical Office publications].

"Studie Naturbewusstsein 2011." [Nature Awareness Study]. Federal Ministry for the Environment, Nature Conservation and Nuclear Safety.

“Testbetriebnetz." [Federal Test Enterprise Network]. Federal Ministry of Food, Agriculture and Consumer Protection.

“Waldbericht der Bundesregierung 2009." [Forest Report of the Federal Government]. Federal Ministry of Food, Agriculture and Consumer Protection.

"Waldklimafonds 2013." [Forest Climate Fund]. Federal Ministry of Food, Agriculture and Consumer Protection and Federal Ministry for the Environment, Nature Conservation and Nuclear Safety.

“Waldstrategie 2020" (2011). [Forest Strategy 2020]. Federal Ministry of Food, Agriculture and Consumer Protection.

\subsection{Lithuania}

Lithuanian country Report was not delivered. 


\subsection{Norway Country Report}

Odd Inge Vistad and Vegard Gundersen, Human Dimension Department, NINA

In Norway, $37 \%$ of the land area is covered by forests, and forest is the most common nature type surrounding the more than 900 villages and cities (Gundersen et al. 2006). Governmental programs to improve the quality and quantity of outdoor recreation in general, are to a large extent also relevant for forest areas. In this context, Norway has several governmental programs and strategies for outdoor recreation initiated by Ministry of Environment (MD) and the Norwegian Directorate for Nature Management (DN), based on several Acts (MD 1957, MD 2008, MD 2009), White papers (MD 2001, MD 2002) and official handbooks (DN 1994, DN 2003a, DN 2003b, DN 2004). The first national strategy for Friluftsliv (Outdoor recreation) was presented already in 1972 (FD 1972). To maintain outdoor recreation traditions, in addition to increased focus on public health and well-being in the population (MD 2013), have been the main drivers for these governmental efforts. Additional to the strategies for promoting recreation in urban proximate nature, several programs for protection of forests as nature reserves, national parks or as important habitats for biodiversity, have also gained increased governmental focus on recreation and tourism in such areas (FD 2003, MD 2009a).

\subsubsection{Recreation and tourism indicators in policy documents}

There are several national documents stating and describing the political goals for management of forests and forestry in Norway, and many of them are also referring to international obligations and agreements. A new Forestry Act (LMD 2005) was approved in 2005, and a White Paper on Agriculture and Food policy (LMD 2011) was presented in 2011, with a chapter on "Sustainable value chains for forests and forestry." The reason for this chapter was to stimulate the forest industry and other kinds of forest related value creation, combined with ambitious goals concerning forests and energy needs, climate change, natural and cultural environment, outdoor recreation and public health improvement. The White Paper presents several measures for achieving sustainable forestry, and in the chapter "Organizing/facilitating for outdoor recreation and health" a new co-action model between forest owners, NGOs 
and public authorities is proposed, in order to increase forest visitation and improve public health and welfare. It also proposes a more goal directed environmental effort in forestry and a yearly report on "knowledge about conditions and developments on forests- and environmental values" (SSB 2008).

The short policy booklet "Norwegian Forests - Policy and Resources" (Det norske skogselskap 2011, produced on behalf of the Ministry of Agriculture and Food) presents and summarizes the main policy instruments for sustainable forest management: "The main objectives of the Forestry Act are to promote sustainable forest management with a view to promote active, local and national economic development, and to secure biological diversity, consideration for the landscape, outdoor recreation and the cultural values associated with the forest" (p. 5). The first page, after this introduction, presents the social and cultural goals and qualities, under the heading "An asset for the public:"

- "Free, public access to land, including forests, is an old and important principle in Norway. The general public may use the forests for recreational activities and sports at any time of year. Public access to nature is enforced through the Outdoor Recreation Act. Motorized recreational activity is prohibited off-road.

- Traditional activities such as berry picking and mushrooming are still important, while modern activities such as off-road biking are increasingly popular. In order to prevent forest fires, the public is allowed to collect dry wood and make campfires in the forest from 15th September to 15th April only. Both municipalities and nongovernmental organizations help maintain a vast network of trails for hiking and cross-country skiing.

- The principle of public access is underlined by the forest policy and the environmental standards used by forest owners. When practicing forestry, forest owners are obliged to clear trails and ski tracks, and to repair damages caused by forestry machinery. The forestry sector contributes to outdoor activities by building and maintaining forest roads and by carrying out silvicultural measures to increase the accessibility of forests.

- Norwegian forests are often mentioned as important for public health and as an educational arena for children and youth. Using the forests for recreation and sports can have a positive impact on both physical and mental health. 
- Hunting and fishing are also important forest activities in Norway. The right to hunt and fish is an exclusive right reserved landowners, but the public is granted the right to fish in lakes and rivers by purchasing licenses. Hunting licenses are also sold, which gives the public the possibility to hunt in privately owned forests, on common land and in municipal and state-owned forests" (Det norske skogselskap 2011).

In 2005 a new Forestry Act was approved, replacing the Act from 1965. The objects clause $(\S 1)$ states that the goal with the act is "... to promote a sustainable management of the forest resources aiming at active local and national value creation, and to secure bio-diversity, landscape concerns, outdoor recreation and the cultural values in the forest" (our translation). Several environmental and recreational NGOs criticized the act for not taking the environmental concerns in the preamble seriously in the following sections of the act. A follow-up Regulation on sustainable forestry (LMD 2006) was approved and tied to the Forestry Act, primarily to give more specific rules on how to achieve sustainable forestry and long term resource management (including concerns for "outdoor recreation, landscape and cultural values)." The responsibility for such concerns mainly belongs to the forest owner ("freedom under responsibility)." The forest owner shall be aware of the environmental values in his/her own forest and allow for environmental concerns when implementing any action in the forest. The premise is that "forest and environmental resources" in the actual forest are documented, and that a plan for management of these resources is developed. Here, documentation and registration primarily means documentation of bio-diversity, key habitats, and other important biotopes in forests.

The most specific demands or recommendations in this Regulation are connected to the voluntary certification system called Living Forests Standard for sustainable forest management in Norway (1999), later called LF. This is a collection of standards for sustainable forest management, first established in 1998 and later revised in 2006, as a consensus between stakeholders in forest management and the forest industry, environmental and outdoor recreation organisations, trade unions and consumer interests - called the Living Forests Council. In the public hearing of the Regulation on sustainable forestry this linking to Living Forests was heavily criticized by e.g. several environmental and outdoor recreation NGOs, since it is a voluntary certification system. They demanded specific environmental and social standards in the Regulation, but based on the agreements in LF, since there is risk of breakdown in the LF cooperation. And that is exactly what happened; 1st July 2010 the agreement in LF 
Council ended, and the cooperation is still not re-established. However, Norwegian forest have since then been certified by the Pan European Forest Certification (PEFC Norway 2013) including exactly the same standards and the same documentation reports as LF.

Nine objectives are listed in PEFC, two of them especially relevant for social and cultural aspects:

\section{A forest management that}

- Ensures that Norwegian forests provide the basis for varied outdoor recreation where nature can be experienced in all its richness.

- Helps to preserve cultural monuments sites and valuable cultivated landscapes.

PEFC also refers to the international forest certification term High Conservation Value Forest (HCVF), defined in four categories. One of them is "Forest areas fundamental to meeting basic needs of local communities and/or critical to local communities' traditional cultural identity."

In the requirement section of the PEFC Standard, social and cultural aspects are presented like this:

\section{Outdoor recreation}

Experiencing nature is an essential part of outdoor recreation. This section of the Standard is intended to contribute to ensure opportunities for access to and appreciation of nature in forest.

\section{- Requirements and rules}

a) Forest management activities must consider maintaining the quality of outdoor experiences, especially along hiking and skiing trails.

b) The public has the right of unimpeded access to the forests, as well as to pick berries and mushrooms within the constraints set by the Open-air Recreation Act and other legislation.

c) All commercial activity in forest areas must be conducted in such a way that the de facto content of the right of unimpeded access is maintained. 
d) Within the framework of reasonable commercial exploitation and privacy, the forest owner must contribute to appropriate solutions for constructing hiking and ski trails, rest areas etc. and for outdoor areas for nurseries, schools and before- and after-school programmes, and grant permission for such when they do not conflict with important commercial or ecological considerations. This does not alter the rights pursuant to the Open-air Recreation Act.

e) The section "Buffer zones" is no impediment to the establishment of fishing spots, rest areas and overlooks where they do not conflict with important commercial or ecological considerations.

\section{- Explanations}

a) Hiking and ski trails mean all hiking and ski trails that are marked in the field, that appear on the N50 map series or have an equivalent use or appear clearly in the landscape.

\section{Cultural monuments and sites and cultural environments}

This section of the Standard is to ensure that monuments and sites and smaller traditionally cultivated fields in the forest landscape are preserved.

- Requirements and rules

a) In addition to taking care of automatically protected monuments and sites, other valuable monuments and sites shall also be taken into account. This includes a prohibition against actively establishing new forests on traditionally cultivated fields smaller than 0.5 hectares in the forest landscape. In exceptional cases, forest may be established where the redirected use is approved by the municipal authority pursuant to Section 9 of the Land Act, assuming that this is not in conflict with the interest of valuable monuments and sites or cultural environments.

b) It is the forest owner's responsibility to familiarise himself with the cultural monuments and sites in the forest that are registered and take this into account in harvesting and forest management. A good tool for this is to ensure correct marking of known monuments and sites and cultural environments in the forest management plan. 
- Explanations

a) All monuments and sites from before 1537 and all Sami monuments and sites more than 100 years old are automatically protected.

b) Cultural monuments and sites mean all traces of human activity in our physical environment, including places associated with historical events, beliefs and traditions. In forests there will be numerous monuments and sites not automatically protected because of age. Also among these there are valuable monuments and sites that shall be taken into consideration.

c) Cultural environment means areas where a monument or site forms part of a larger entity or context.

\section{Landscape plan}

This section of the Standard is intended to ensure that forest management protects interests across stand and holding boundaries.

\section{- Requirements and rules}

a) For parcels over 1,000 hectares, the planning and managing of forests shall take into account considerations of landscape ecology over and above the individual stand. Important landscape ecology features that cross property lines shall also be considered as far as possible on smaller parcels as well.

b) For example integrated landscape planning involves attaching importance to:

i) Locally adapted forest management

ii) Consideration of the visual appearance of the local landscape

iii) Percentage of mature forest

iv) The need for restoration habitats

v) Recreation, hiking trails, ski trails

vi) Forestry roads

vii) Game habitats, mating areas for capercaillie (wood grouse).

- Explanations

a) Landscape ecology is the interaction among ecological processes and the mosaic in the landscape. A landscape ecological perspective means that different natural environments must be found in the landscape at any given time. 
b) Consideration of the visual appearance of the local landscape means that the form of the logging area and use of open harvesting methods (i.e. clear-cutting and seed tree methods) are to be shaped and adapted to the landscape features.

c) Hiking and ski trails mean all hiking and ski trails that are marked, that appear on the N50 map series or have an equivalent use or appear clearly in the landscape.

Considerations of game habitats means planned management of mating areas for capercaillie (wood grouse), forests adjacent to nesting sites for birds of prey (northern goshawk) etc.

The PEFC scheme leaves forest companies with less stringent sustainable management standards than the FSC (Forest Stewardship Council), and a greater leeway to apply those standards (Gulbrandsen 2005a, b). Different strategies in for example Norway (PEFC) and Sweden (FSC) may be explained by differences in public policy and government support, advocacy-group and market pressure, and industry structure (Gulbrandsen 2005a).

The website State of the Environment Norway (2012) is the central information channel for information about the state of Norwegian environment. "Outdoor recreation" and "Forests and mountains" are represented as two of thirteen main categories. The information is organized under the following headings: Topics, goals and indicators, and maps and data. The content is produced and quality checked by the Norwegian environmental agencies.

"Forest" is presented with eleven National targets and twenty related indicators, but none of them are social or cultural targets or indicators. Under "Outdoor recreation" four national targets are listed (http://www.environment.no/miljomal/Mal-og-nokkeltall/Friluftsliv/):

Participation in outdoor recreation, Safeguard valuable areas, Right of access and Planning to promote active outdoor recreation (see next chapter) (State of the Environment Norway2012).

As we have seen in the presentation above, Norway do not have one single process, but several processes for forest related policy development and implementation, and recreation and tourism have an overall weak formal representation. For this reason there are several documents that combine and constitute the national strategies, and the most important elements are the white paper on forest policy (LMD 1999), the Forestry Act (LMD 2005), Regulation on sustainable forestry (LMD 2006) the annual national budget, the forest policy instruments and the Living Forests (now PEFC Norway) processes. Despite lack of one single formal process 
the Government states (LMD 1999) that the processes are guided by the following principles: Participation, holistic and inter-sectorial approach, iterative with long-term commitment, capacity building, consistency with national legislation and policies, integration with national sustainable development strategies, consistency with international commitment, institutional and policy reform, ecosystem approach, partnership for implementation and awareness raising. However, implementation using these elements and strategies in a formal way have probably discriminated social values connected to recreation and tourism.

\subsubsection{Recreation and tourism indicators used and reported}

Some of the main programs for outdoor recreation and tourism in forest (like the Living forests) are more like recommendations and qualitative descriptions than strictly defined and quantifiable standards and indicators to be followed by monitored data.

Statistics Norway (SSB 2011) has the main responsibility for meeting the need for statistics in the Norwegian society, and presents statistics relevant for outdoor recreation (activities, physical activity, sports, participation, recreational plans, physical barriers, and access) and tourism. However, these statistics are about the general situation and development in Norway, and not specific for forest areas. Statistics Norway collects data concerning several governmental indicators within the field of recreation and tourism. Statistics Norway also produces statistics about municipal investment in outdoor recreation.

Goals and indicators presented by State of the Environment Norway (2012) - see the chapter above:

\section{National goal of participation in outdoor activities}

Everyone will have the opportunity to take part in outdoor recreation as a healthy and environmentally sound leisure activity that provides a sense of well-being both in their local communities and further afield in the countryside.

- Proportion of the population who take part in outdoor recreation activities (National survey).

- Number of schools taking part in the "environmental rucksack" project.

- Proportion of homes, schools and day-care centres in selected towns and urban areas with safe access to nearby outdoor recreation areas within a distance of 500 metres. 


\section{Safeguard valuable areas}

Areas of value for outdoor recreation will be safeguarded and managed in a way that maintains the natural environment.

- Number of new outdoor recreation areas designated per year with financial assistance from the state (Number, and area per county).

- Percentage of outdoor recreation areas designated with financial assistance from the state for which management plans have been drawn up.

\section{Right of access}

Access rights to uncultivated land will be maintained.

- Proportion of the population who know something about their access rights.

- Proportion of the 100-metre belt along the shoreline from Østfold to Hordaland county inclusive that is regarded accessible for the public.

\section{Planning to promote active outdoor recreation}

Municipal, county and regional planning will promote active outdoor recreation and create local communities that promote health and a sense of well-being and are environmentally sound.

- Number of municipal and regional outdoor recreation plans.

Of all these indicators only three are followed up with presentation of a Status, namely the indicators "Proportion of the population who take part in outdoor recreation activities," "Number of new outdoor recreation areas designated per year with financial assistance from the state" and "Number of schools taking part in the 'environmental rucksack' project."

Engelien and Schøning (2001) presents different methods to monitor key indicators based on SSB data, concerning physical access of recreational areas from day-care centres, schools and from homes have been tested and two main indicators were developed:

- The proportion of homes, schools and day-care centres that have safe access to playgrounds and recreational areas (minimum 5 daa) within a distance of 200 meters.

- The proportion of homes, schools and day-care centres that have access to recreational areas (minimum 200 daa) within a distance of 500 meters. 
Area indicators for urban proximate recreational areas have been further developed by analyses and results in 2004 (Engelien et al. 2005) and with further improvement of the methodology in 2012 (Engelien 2012). The indicator 2 mentioned here has been included as indicator $1 \mathrm{c}$ ) in the State of the Environment Norway, heading: Outdoor recreation.

Indirectly, different kinds of area classification and surveillance of geographical conditions are often used as indicators of suitability for recreation and tourism. An example is the proportion of protected forest land of different categories or administratively protected key habitats for biodiversity. The Nature Diversity Act (MD 2009a) played a role in achieving the political goal of increasing participation in urban outdoor activities, because the act is a main legal tool for managing large nature areas that are important for recreation and tourism. It is, however, difficult to use the different area categories specified in the Act as indicators of gained recreation and tourism interests, because management strategies on how the protected areas should functions for the visitors are lacking. Another example is the coverage of "wilderness territory" in Norway from 1900 and up to date (Wilderness territory of Norway2013).

A special case concerns the $1,700 \mathrm{~km}^{2}$ forested area on the fringe of Oslo, called Oslomarka. Here some special criteria and indicators were developed for improving the forest management by changing paragraphs in the Forestry Act in 1976. The social values were, and still are, the main reasons for these adaptations in forestry in Oslomarka, and in 2009 the Ministry of Environment developed a completely new Act, called Markaloven, for the same area (MD 2009). Among several actions in the new Act, $\$ 11$ opened for protection of "pristine" forests for the reasons of recreational use and "wilderness" experience (Gundersen et al. 2011). The process of establishing these $\S 11$ - "fairy-tale forest areas", covering approximately 1,700 ha protected areas, will be finished in 2013 .

Infrastructure like forest roads and trails are often important for recreation and tourism, but forests roads can also reduce recreational qualities. Until 2008 SSB yearly presented forest statistics on total length (in kilometre) of forest roads, as well as amount of new and rebuilt forest roads. The figures were again updated in 2011 (48,000 km in total, $155 \mathrm{~km}$ new and 42 $\mathrm{km}$ rebuilt roads). Such information is primarily relevant for recreational interest when downscaled to the local level. We are not aware of any statistics on the length of different standards of forest trails or paths.

National surveys on level-of-living include outdoor recreation activities (Sports and Outdoor... 2013), describing participation and main trends in different outdoor recreation activities since the 1970s. The latest survey was carried out in 2011 (Vrålstad et al. 2011). These sur- 
veys are the most important datasets concerning participation in outdoor recreation in Norway. Odden (2008) has presented and discussed the development of Norwegian Friluftsliv in his PhD-work, based on all the SSB-surveys from 1970 to 2004.

\subsubsection{The status of recreation and tourism indicators used in forest management}

There is no reason to doubt the central political position of the outdoor recreation culture in Norway, and the high ambitions and the goals in policy documents and in the certification system (Living Forests/PEFC) for stimulation of outdoor recreation in forests and taking care of recreational interests related to forestry. But no specific social indicators are identified in the forest monitoring system that can document conditions or change. On the other hand: we have the oldest monitoring system in the world when it comes to measurement of stand volumes, growth and biomass production in our forests, the Norwegian National Forest Inventory, established in 1919. Since then the whole country has been assessed nine times (Statistikk fra Landsskogstakseringen 2013). In addition the bio-diversity and biotopes in forests have been monitored systematically since 2000, based on a set of manuals, specific methodologies and indicators. The aim is to present knowledge on biological conditions for use in the development of local forestry plans (Miljøregistrering i skog 2013).

Norway does, of course, intend to continue reporting to e.g. Forest Europe, since it is expected and relevant for international comparison. But the quality and usefulness of the reported social data are doubtful since they primarily are based on interpretation of national survey data on recreational behaviour from Statistics Norway. Such data have limited value on the regional and local level concerning practical forestry and forest management in relation to social goals and interests.

Except from special measures due to the high recreational and landscape concerns in many urban forests, the Norwegian political and management culture related to outdoor recreation seems to be based on a sort of "paradisiac" view of the permanent good conditions for outdoor recreation in (inland) Norway: We have a long outdoor life tradition, an open access to all outfields (e.g. forests), lots of undeveloped nature (e.g. semi-natural forests) and a low population. In other words: Norway has the perfect conditions for outdoor recreation. One consequence is that social monitoring and documentation are not (politically) regarded necessary. Still, it is probably wrong to conclude that Norwegian authorities resist social monitoring; it is 
more a question of not seeing the need for monitoring and documentation (except for international reporting and comparison) - yet.

At present, the goals concerning forests and outdoor recreation, quality of life, public health in policy documents etc. are ambitious, but primarily at a rhetorical level. It is a sort of Catch-22 logic: A possible "need" for documentation of social conditions (because of "negative development tendencies for the recreational interests?)" will not be revealed without implementing a social monitoring system. But such documentation is at present not regarded necessary, so social monitoring has not been implemented, therefore the knowledge base for assessing the documentation need is not present.

\subsubsection{References}

Det norske skogselskap (The Norwegian Forest Association) (2011): "Norwegian Forests. Policy and Resources." Oslo. Available at: http://www.regjeringen.no/en/ dep/lmd/documents/Guidelines-and-brochures/2011/norwegian-forests.html? id=650026 [Cited 30th July 2013].

DN (Directorate for nature management) (1994): "Planlegging av grønnstruktur i byer og tettsteder." DN-Håndbok No. 6-1994.

DN (2003a): “Grønn by - arealplanlegging og grønnstruktur." DN-håndbok No. 23-2003.

DN (2003b): “Marka - planlegging av by- og tettstedsnære naturområder.” DNhåndbok nr. 24-2003.

DN (2004): "Kartlegging og verdsetting av friluftslivsområder." DN-Håndbok No. 252004.

Engelien, E. and Schøning, P. (2001): "Friluftsliv og tilgjengelighet - metode for beregning av nøkkeltall.” Kongsvinger: SSB Rapport No. 41. Statistics Norway. Available at: http://www.ssb.no/natur-og-miljo/artikler-og-publikasjoner/friluftslivog-tilgjengelighet?fane $=$ om [Cited 30th July 2013].

Engelien, E., Steinnes, M. and Bloch, V.V.H. (2005): “Tilgang til friluftsområder. Metode og resultater 2004." SSB Notater 2005/15. Available at: http://www.ssb. no/natur-og-miljo/artikler-og-publikasjoner/tilgang-til-friluftsomraader2004?fane=om. [Cited 30th July 2012].

Engelien, E. (2012): “Tilgang til rekreasjonsareal og nærturterreng. Dokumentasjon av metode." SSB Notater 20/2012. Available at: http://www.ssb.no/natur-ogmiljo/artikler-og-publikasjoner/tilgang-til-rekreasjonsareal-og-naerturterreng. [Cited 30th July 2012].

FD (Ministry of finance) 1972 (1972): “Spesialanalyse Friluftsliv.” Attachment no. 6 to St. Meld. No. 71 (1972-73).

FD 2003 (2003): “Tilleggsbevilgninger og omprioriteringer i statsbudsjettet medregnet folketrygden 2003." St.prp. No. 65 (2002-2003).

Gulbrandsen, L. (2005a): "Explaining different approaches to voluntary standards: A study of forest certification choices in Norway and Sweden." Journal of Environmental Policy \& Planning Vol. 7, pp. 43-59.

Gulbrandsen, L. (2005b): "The effectiveness of non-state governance schemes: A comparativ study of forest certification in Norway and Sweden." International Environmental Agreements 5, pp. 125-149. 
Gundersen, V., L. H. Frivold, T. Myking, B.-H. Øyen (2006): “Management of urban recreational woodlands: The case of Norway." Urban Forestry \& Urban Greening Vol. 5, pp. 73-82.

Gundersen, V., Skår, M., Tangeland, T. and Vistad, O. I. (2011): “Protection of recreational areas in Oslomarka in accordance with markaloven $\S 11$ - Review, criteria and inventory method." - NINA Rapport 664, 78 p.

Living Forests Norway (1999): "The Living Forests standards for sustainable forest management in Norway, Oslo." Available at: http://www.levendeskog.no/levendeskog/ vedlegg/51Levende_Skog_standard_Engelsk.pdf. [Cited 30th July 2013].

LMD (Ministry of Agriculture and Food) (1999): "Verdiskaping og miljø - muligheter i skogsektoren." St. meld. nr. 17 (1998-99).

LMD (2005): "Lov om skogbruk." LOV-2005-05-27-31. Available at: http://www. lovdata.no/all/nl-20050527-031.html [Cited 30th July 2013].

LMD (2006): "Forskrift om berekraftig skogbruk." FOR 2006-06-07. Available at: http://www.lovdata.no/for/sf/ld/ld-20060607-0593.html [Cited 30th July 2013].

LMD (2011): “Landbruks- og matpolitikken.” Velkommen til bords. St. meld. nr. 9 (2011-2012).

MD (Ministry of environment) (1957): “Lov om friluftslivet.” LOV-1957-06-28-16. Available at: http://www.lovdata.no/all/nl-19570628-016.html [Cited 30th July 2013].

MD (2001): "Friluftsliv - Ein veg til høgare livskvalitet." St. meld. nr 39 (2000-2001). Miljøverndepartementet, Oslo.

MD (2002): “Om bedre miljø i byer og tettsteder.” St. meld. nr 36 (2001-2002).

MD (2008): “Lov om planlegging og byggesaksbehandling.” LOV-2008-06-27-71. Available at: http://www.lovdata.no/all/nl-20080627-071.html [Cited 30th July 2013].

MD (2009): “Lov om naturområder i Oslo og nærliggende kommuner.” LOV 2009-06-05. Available at: http://www.lovdata.no/all/hl-20090605-035.html [Cited 30th July 2013].

MD (2009a): "Lov om forvaltning av naturens mangfold." LOV-2009-06-19-100. Available at: http://www.lovdata.no/all/nl-20090619-100.html. [Cited 30th July 2013].

MD (2009b): "Om lov om forvaltning av naturens mangfold (naturmangfoldloven)." Ot.prp. No. 52 (2008-2009), 479 p.

MD (2013): "Nasjonal strategi for et aktivt friluftsliv. En satsing på friluftsliv i hverdagen; 2014-2020." T-1535.

"Miljøregistrering i skog 2013." Norsk institutt for skog og landskap. Available at: http://www.skogoglandskap.no/temaer/miljoregistrering_i_skog [Cited 18th July 2013].

Odden, A. (2008): "Hva skjer med norsk friluftsliv? En studie av utviklingstrekk i norsk friluftsliv 1970-2004." PhD Thesis no. 289. Trondheim: Department of Geography, NTNU.

PEFC Norway 2013. Available at: http://www.pefcnorway.org/ [Cited 18.07.2013].

"Sports and outdoor activities, survey on living conditions (2011): Statistics Norway. Available at: http://www.ssb.no/english/subjects/07/02/50/fritid_en [Cited 18th July 2013].

SSB (Statistics Norway) (2008): "Forestry Statistics 2008." Statistics Norway.

SSB (2011): "Forestry Statistics 2011." Statistics Norway.

"Statistikk fra Landsskogstakseringen" (2013). Norsk institutt for skog og landskap. Available at: http://www.skogoglandskap.no/temaer/statistikk_fra_ landsskogstakseringen [Cited 18th July 2013].

"State of the Environment Norway 2012." Available at: http://www.miljostatus.no/ [Cited 18th July 2013]. 
Vrålstad, S., Wiggen, K.S. and Thorsen, L.R. (2011): “Levekårsundersøkelsen EU-SILC 2011." Tema: Friluftsliv, organisasjonsaktivitet, politisk deltakelse og sosialt nettverk. Dokumentasjonsrapport. Documents 34, Statistics Norway.

“Wilderness Territory in Norway (1900-1992)" (2013). Available at: http://www. grida.no/prog/norway/wildland/. [Cited 18th July 2013].

\title{
6.7 North Western Russia Country Report
}

\author{
Natalia Demidova and Nadezhda Demina (Northern Research Institute of \\ Forestry, Arkhangelsk)
}

Concerning forest, recreation should be considered as recovery of human's strength and energy due to direct communication with nature.

In the Russian Federation, there are laws and different regulatory-legal and regulatory-technical documents of federal significance which concern the issues of forest usage for implementation of recreational activity: appropriate articles of the Russian Federation Forest Code (2006), the Russian Federation Land Code (2001), other federal laws referring the issues of forest usage for implementation of recreational activity.

Table 1: Regulatory-technical documents which regulate issues of recreational activity in RF

\begin{tabular}{|c|c|c|}
\hline $\begin{array}{l}\text { No } \\
1\end{array}$ & $\begin{array}{l}\text { Name of the Document } \\
2\end{array}$ & $\begin{array}{l}\text { Reglamentation } \\
3\end{array}$ \\
\hline 1 & $\begin{array}{l}\text { Temporary technique of recreational loads } \\
\text { definition on natural complexes at the } \\
\text { organization of tourism, mass daily rest and } \\
\text { temporary norms of these loadings. Approved } \\
\text { by USSR State Forestry service, } 1987 .\end{array}$ & $\begin{array}{l}\text { The technique establishes methods of recreational loadings } \\
\text { definition. } \\
\text { There is demand for revision and completion of the docu- } \\
\text { ment regarding regulations of standards for improvement of } \\
\text { the green and forest-park zones. }\end{array}$ \\
\hline 2 & $\begin{array}{l}\text { OST } 56-84-85 \text {. Use of the forests in the } \\
\text { recreational purposes. Terms and defini- } \\
\text { tions. Approved by the order of Goskomles } \\
\text { of the USSR, November } 29,1985 \text {, №180 }\end{array}$ & $\begin{array}{l}\text { This document establishes terms and definitions of the main } \\
\text { concepts in the field of forests use in the recreational pur- } \\
\text { poses. It demands specification and updating of the formula- } \\
\text { tion of separate terms }\end{array}$ \\
\hline 3 & $\begin{array}{l}\text { All-union standards for forests taxation (the } \\
\text { Directory, Moscow, 1992) }\end{array}$ & $\begin{array}{l}\text { Standards regulate a question of forests taxation for recrea- } \\
\text { tional purposes (chapter 4, item 82) }\end{array}$ \\
\hline 4 & $\begin{array}{l}\text { An order for contract preparation and } \\
\text { conclusion of the forest areas lease being in } \\
\text { the state or municipal ownership. The order } \\
\text { of the Ministry of Agriculture of the Russian } \\
\text { Federation, February 12, 2010, №. } 48\end{array}$ & $\begin{array}{l}\text { The document establishes a lend-lease of sites of forest fund } \\
\text { for implementation of all types of use of forests including } \\
\text { implementation of recreational activity. It demands correc- } \\
\text { tion on a regulation of the green and forest-park zones }\end{array}$ \\
\hline 5 & $\begin{array}{l}\text { Criteria and indicators of sustainable forest } \\
\text { management of the Russian Federation. } \\
\text { Approved by Rosleshoz order, February 5, } \\
\text { 1998, №21 }\end{array}$ & $\begin{array}{l}\text { This document is intended for justification of forest policy of } \\
\text { the Russian Federation, and also in the subjects of the Russian } \\
\text { Federation. Indicators for criteria assessment are selected with } \\
\text { account of possibility use of existing forestry information. } \\
\text { Terms and definitions of separate criteria need to be brought } \\
\text { into accordance with the new forest legislation }\end{array}$ \\
\hline
\end{tabular}


The mainframe regulatory document which regulates forest relations while implementation of recreational usage of forests of Russian Federation is Article 41 of the Russian Federation Forest Code (2006). Table 2 demonstrates the list of Federal laws which in a varying degree concern the issues of regulation of forest relations in recreational purposes.

Table 2: The list of federal laws regulating organization and management of forest exploitation in the Russian Federation including the issues of forest use for recreational activity implementation

\begin{tabular}{ll} 
No & Name of the Document \\
$\mathbf{1} n$ & $\mathbf{2}$ \\
\hline 1 & $\begin{array}{l}\text { The Forest Code of the Russian Federa- } \\
\text { tion, December 04, 2006, № 200-FZ }\end{array}$
\end{tabular}

The scope of the document

2 Federal law "On implementation of the Forest Code of the Russian Federation," December 04, 2006, № 201-FZ

3 The Land Code of the Russian Federation, October 25, 2001, № 136-FZ

4 The Water Code of the Russian Federation, June 03, 2006, № 74-FZ

5 The Civil Code of the Russian Federation (part one), November 30, 1994, № 51-FZ

The civil code of the Russian Federation (part second), January 26, 1996, № 14-FZ

6 The City-Building Code of the Russian Federation, December 29, 2004, № 190-FZ

7 The Criminal Code of the Russian Federation, June 13, 1996, № 63-FZ

8 The federal law "On land improvement," January 10, 1996, No. 4-FZ

9 The federal law "On entrails," February 21,1992 , No. 2395-FZ

10 The federal law "On transfer of lands or land sites from one category into another," December 21, 2004, No. $172-F Z$

The legal document which regulates forest relations in the sphere of forest use, protection and reproduction, including questions of forests use for implementation of recreational activity

It includes all changes in the forest legislation in connection with introduction of the new Forest Code of the Russian Federation, as well as amendments to other federal laws in the sphere of use, protection and reproduction of forests

The document regulates an order of lands use and protection of recreational purposes

The document regulates forest use and conservation in water protection zones, order of sizes and borders of water protection zones establishment, as well as use of wate objects for the recreational purposes

The document regulates relations regarding the lands-lease and their use

The document defines an order of land sites use at citybuilding activity implementation on the principle of a sustainable territories development

The document establishes the principles of criminal liability defines the content of crimes, establishes types of punishments, other measures of criminal character for crimes in the sphere of forests use

The document establishes an order of lands use for ameliorative actions

The document contains legal and economic bases of complex and rational use and protection of entrails, regulates the relations arising in connection with geological study, use and protection of entrails

The document displays features of lands of forest fund or land sites as a part of such lands of transfer into other category

The document contains the status which provide environ mental protection at forests use 


\begin{tabular}{|c|c|c|}
\hline $\begin{array}{l}\text { № } \\
\text { пா }\end{array}$ & Name of the Document & The scope of the document \\
\hline 12 & $\begin{array}{l}\text { The federal law "About especially } \\
\text { protected natural territories," March } \\
\text { 14, 1995, No. 33-FZ }\end{array}$ & $\begin{array}{l}\text { The document regulates relations in the field of organization, } \\
\text { protection and use of especially protected natural territories } \\
\text { (seven categories) for unique and typical natural complexes } \\
\text { and objects conservation, noteworthy natural sites, objects of } \\
\text { a plant and animal life, their genetic fund, studying of natural } \\
\text { processes in the biosphere and control of change of its condi- } \\
\text { tion, and also ecological education of the population }\end{array}$ \\
\hline 13 & $\begin{array}{l}\text { The federal law "On protection of } \\
\text { Baikal Lake," May 10, 1999, No. 94-FZ }\end{array}$ & $\begin{array}{l}\text { The document displays features of forest exploitation on } \\
\text { protected territories of Baikal Lake, sets restrictions on the } \\
\text { forests use, establishes a priority of restoration of especially } \\
\text { valuable forests }\end{array}$ \\
\hline 14 & $\begin{array}{l}\text { The federal law "On objects of a } \\
\text { cultural heritage (history and culture } \\
\text { monuments) of the population of the } \\
\text { Russian Federation," June } 25,2002 \text {, } \\
\text { No. } 73-F Z\end{array}$ & $\begin{array}{l}\text { The document regulates the relations in the field of conser- } \\
\text { vation, use, promotion and state protection of objects of a } \\
\text { cultural heritage, establishes features of use of the land sites } \\
\text { as a part of forest lands }\end{array}$ \\
\hline 15 & $\begin{array}{l}\text { The federal law "On territories of } \\
\text { traditional environmental use of the } \\
\text { indigenous people of the North, } \\
\text { Siberia and the Far East of the Russian } \\
\text { Federation," May 07, 2001, No. 49-FZ }\end{array}$ & $\begin{array}{l}\text { The document establishes legal bases of education, protec- } \\
\text { tion and use of territories of traditional environmental } \\
\text { management of the indigenous people for conducting } \\
\text { traditional environmental management, including forest } \\
\text { exploitation }\end{array}$ \\
\hline 16 & $\begin{array}{l}\text { The law of the Russian Federation "On } \\
\text { the State Border of the Russian } \\
\text { Federation." April 1, 1993, No. 4730-1 }\end{array}$ & $\begin{array}{l}\text { The document establishes a forest exploitation regime in a } \\
\text { near-border zone and within the State border }\end{array}$ \\
\hline 17 & $\begin{array}{l}\text { The law of the Russian Federation " } \\
\text { On land payment," October 11, 1991, } \\
\text { No. } 1738-1\end{array}$ & $\begin{array}{l}\text { The document regulates amounts of payment for lands of } \\
\text { forest fund use for forest exploitation }\end{array}$ \\
\hline 18 & $\begin{array}{l}\text { The federal law "On general principles } \\
\text { of the organization of legislative } \\
\text { (representative) and executive bodies } \\
\text { of the government of subjects of the } \\
\text { Russian Federation," October } 6,1999 \text {, } \\
\text { No. } 184-\text {-FZ }\end{array}$ & $\begin{array}{l}\text { The document establishes an order and norms of forest } \\
\text { harvesting implemented by population for own needs and } \\
\text { regulates single issues on providing authorities by owners of } \\
\text { forest sites }\end{array}$ \\
\hline 19 & $\begin{array}{l}\text { The Code of the Russian Federation } \\
\text { on administrative offenses, December } \\
\text { 30, 2001, No. 195-FZ }\end{array}$ & $\begin{array}{l}\text { The document defines responsibility for violations in the } \\
\text { field of environment protection and nature use, including } \\
\text { forest exploitation }\end{array}$ \\
\hline
\end{tabular}

Features of forest use for implementation of recreational activity also are shown in regulatory documents which are widely used in forestry, and the main of them is the following: Regulations of forest usage for implementation of recreational activity approved by the order of the Ministry of Natural Resources of Russian Federation of the 24th April 2007 № 108.

Lands of recreational purpose are considered as land areas assigned in accordance with established procedure, set aside and used for organized mass recreation and tourism (land areas occupied with territories of holiday houses, resorts, health centers, camping sites, sports and fit- 
ness complexes etc.). Also among lands of recreation purpose are lands of suburban green and park zones i.e. lands outside the city limits occupied with forest, woodland parks and other green stands which perform protective and sanitary functions and represent recreation places of the inhabitants (The Land Code of the Russian Federation 2001).

VNIILM researchers established that total area of forest lands which are used for different types of recreation contain more than $60 \%$ of protective forests (except forests of the state natural reserves, specially protected zones of national parks, reserved forest areas of natural parks, specially protective forest areas, pretundra forests etc.) and other forests which possess nature conservation significance. Total area of forest lands used for different types of recreation totals more than $560 \mathrm{mln}$ ha or more than $60 \%$ of total area of forest fund lands and lands not included in forest Fund. Forest areas on the territory of national parks used for different types of recreation make up 39\% of total area of parks of federal significance. Approximately the same ratio remains in natural parks of regional significance. Tourist activity is also realized in protection zones on a third of areas of existing reserves. Attendance of recreation places in the most of Russian mastered forests is carried out almost year-round.

It was determined more than forty years ago that recreation nature management needs scientific ground. Certain success was already achieved: the main regularities of formation and development of recreation systems were formulated, recreation nature management became considered as independent part of forest exploitation etc. However additional work on appropriate correction of earlier elaborated methods, basis of new methods and regulations of recreation nature management is required with the economy transfer to market relations.

According to the opinion of many researchers, it's necessary to have a Cadastre of recreation forests based on the assessment of their recreation potential for efficient use of such forest resources in each region of Russian Federation (Shalimova et al. 2001). Inventory of forests of recreation assignment (FRA) should be carried out on the base of forest management and woodland park management which provide implementation of a complex of natural taxation-exploration works and first of all of landscape taxation of stands assessing environment improving, landscape-architectural and decorative properties of the forest.

However the problem consists in that the existing nowadays assessment scales are far from being universal.

One of the most serious disadvantages of these scales is incomparability of obtained results - different rates are estimated with different amount of points, classes etc.; in some cases to estimate the rate, there 
are used qualitative characteristics (good, bad, medium, high, low etc.) which doesn't allow to conduct mathematical data processing.

Existing method of estimation of stand recreation potential elaborated by S. L. Rysin provides allotment assessment of a stand by 29 indices united into three main groups: forest attractiveness, its comfort for holidaymakers and resistance to recreation impact; all indices are estimated with five-mark grading system (0 to 4 points) (Rysin 2003).

According to the materials of other researchers, not less than 10 parameters could be added to the mentioned ones which indicate great complexity of this problem of definition of recreation potential (RP). For integral estimation of recreational potential, all stands are divided into 4 classes of recreation value (CRV); stands of the 1st CRV are the most challenging for recreational use and in the stands of the 4th CRV recreational forest management should be stopped till conduction of a complex of measures aimed at their restoration and increase of recreational value would be implemented. Application of the above mentioned method of determination of recreational potential gives an opportunity to simplify the work on compiling the Cadastre of forests of recreational assignment due to standardization and formalization of represented data which characterize recreational value of each area.

In this respect, data of forest monitoring possess great significance.

Results of monitoring observations of forest conditions with determination of their recreational potential estimation give a basis for objective identification of character and degree of damage caused by recreation and other kinds of anthropogenic impact. Meanwhile it should be mentioned that studies of consequences of recreational forest management in the most of regions of our country are carried out occasionally and using different methods and components of forest biogeocenosis. Complex forest recreational potential estimation including assessment taking into consideration forest distribution into forest zones and areas is missing.

All the diversity of social functions of forest recreational activity can be reduced to the following three groups: medical-biological, technological and psychological-aesthetic. Each of these groups associated with certain types and forms of activity but at the same time these groups don't have insuperable borders since the most of social demands are interrelated and interdependent.

- Medical-biological functions: when the degree of comfort of natural landscape environment for recreation is determined.

Usually there are distinguished two sides of this group of forest recreation functions: treatment and recovery. Treatment using natural 
potential of resort areas is implemented for health recovery of people who had any illness and need the continuation of medicinal process. Medical-biological functions provide for wide development of active kinds of recreational activity and also for diversity of activities as necessary condition of efficiency of measures for relaxation.

- Psychological-aesthetic functions: when the character of emotional impact of natural environment on holidaymakers, attractiveness of natural and cultural-historical objects are analyzed.

Either development of forest recreation or solution of many other social-economic problems of the region depends on in which degree cultural heritage would be involved into this sphere.

- Technological (economic) functions: when fitness of resources for organization of different types of tourism and recreation and opportunity of forming specialized and multifunctional territoryrecreational complexes are determined (Bogolubova 2009).

Economic functions of forest recreation as a rule are connected with medical-biological and psychological-aesthetic functions.

Together with traditional economic problems, recreational activity in present conditions allows to solve also specific problems among which two main issues are standing out especially. The first is self-provision of the population with mushrooms and berries, with fish and game and collection of which are implemented usually in the form directly connected with forest recreation. The second is wild medicinal plants harvesting of which is directly connected with recreation and also provides the increase of the human resistance to diseases due to "forest therapy." These two issues are relevant for Russia and should be taken into consideration while developing measures in the management sphere. Complex character of recreational resources requires combination of the whole three types of estimation for determination of integral value of resources and forms of their efficient use.

It was found that the research on this issue taking into account present conditions of forest complex development and requirements of new forest legislation bear mostly unsystematic character, and lack of unified methodology for determination of recreational capacity and recreational potential of forest areas greatly complicate the establishment of reliable data on recreational load on forest ecosystems. At the same time it was found that only extremely limited amount of methodical documents can be used for scientific analysis and generalization of results since majority of works on studying this problem is a recommendation and their use is difficult due to great differences in the scale of recreational loads. 


\subsubsection{References}

Bogolubova, S.A. (2009): "Ecological and economic evaluation of recreational resources." Moscow, 256 p.

Rysin S.L. (2003): "Methodology and methods of studying the recreational potential of the forest park landscapes." Moscow, pp. 115-135.

Shalimova E.M., Velikotny A.A. and Brunova Z.S. (2001): "Some results of the inventory of protected areas on forest land" [Environmental problems of historical and cultural heritage preservation]. Moscow.

"The Land Code of the Russian Federation," (Federal Law from 25.10. 2001 № 136-FZ).

"The Forest Code of the Russian Federation," (Federal Law from 04.12. 2006, № 200-FZ).

\subsection{Scotland Country Report}

David Edwards

This report outlines the indicators used in Scotland that relate to the social aspects of forests and nature-based tourism. Relevant indicators that are reported for the UK level are also included since they cover Scotland, and the data is likely to be available for Scotland as well.

\subsubsection{Recreation and tourism indicators in policy documents - Indicators of sustainable development}

\section{UK Indicators of Sustainable Development}

A range of sustainable development indicators are published by Defra (the UK Department for Environment, Food and Rural Affairs), available in "Measuring progress: Sustainable development indicators 2010." A new set of indicators is currently under development. See: http://sd.defra.gov.uk/progress/national/annual-review/. The report includes a suite of 68 National Indicators, although none of them report specifically on the social aspects of forests. Of most relevance are the following (Measuring progress... 2010):

- Indicator 37: Active community participation (Informal and formal volunteering at least once a month in the last 12 months).

- Indicator 55: Mobility ((a) Number of trips per person by mode (b) Distance travelled per person per year by broad trip purpose).

- Indicator 57: Accessibility (Access to key services).

- Indicator 60: Environmental quality (Populations living in areas with, in relative terms, the least favourable environmental conditions). 
- Indicator 65: Local environmental quality (Assessment of local environmental quality).

- Indicator 66: Satisfaction in local area (Percentage of households satisfied with the quality of the places in which they live (a) overall (b) in deprived areas).

\section{Scotland Performs}

"Scotland Performs" is a procedure used by the Scottish Government to measure and report on progress of government in Scotland in delivering its overall aim of creating a more successful country, with opportunities for all to flourish through increasing sustainable economic growth. Progress is tracked by 7 Purpose Targets and supported by 16 National Outcomes, and 45 National Indicators. See: http://www.scotland. gov.uk/About/Performance/scotPerforms/indicators (National Indicators 2012).

Targets of relevance to the social aspects of forestry are:

- Increase the percentage of adults who rate their neighbourhood as a good place to live.

- Increase to $95 \%$ the proportion of protected nature sites in favourable condition.

- Improve the state of Scotland's Historic Buildings, monuments and environment.

- Increase the proportion of adults making one or more visits to the outdoors per week.

\subsubsection{Recreation and tourism indicators in policy documents - Indicators of Sustainable Forest Management}

\section{State of Europe's Forests 2011}

As with other European countries, the UK compiles data on indicators at intervals of 4 years for the Ministerial Conference on the Protection of Forests in Europe (FOREST EUROPE). The indicator of most relevance to recreation and tourism is 6.10: Accessibility for recreation and intensity of use (Area of forest and other wooded land where public has a right of access for recreational purposes and indication of intensity of use). The UK returns for each indicator in the 2011 State of Europe's Forests report (FOREST EUROPE... 2011) are available here: http://www.forestry.gov.uk/ website/forestry.nsf/byunique/infd-86hchq (State of Europe's... 2010). 


\section{UK Sustainable Forest Management Indicators 2010}

A set of Sustainable Forest Management Indicators 2010 was first published on 24 June 2010, based on the indicators for State of Europe's Forests 2011. http://www.forestry.gov.uk/website/sfmindic2010.nsf/LUContentsTop?o penview\&RestrictToCategory=1 (Sustainable Forest... 2010).

\section{UK Indicators of Sustainable Forestry 2002}

The Forestry Commission, in association with the Forest Service (Northern Ireland) published "UK Indicators of Sustainable Forestry" on 31st October 2002. The 40 indicators cover a wide range of aspects of sustainable forestry in the UK, and are grouped under six themes, including "People and Forests:" http://www.forestry.gov.uk/forestry/ahen5hzd3r. Indicators under this theme are: E1 Visits to woodland, E2 Extent of open public access, E3 Public awareness, E4 Community involvement, E5 Historic environment and cultural heritage, and E6 Health and safety (UK Indicators... 2002).

\section{Scottish Forestry Strategy}

The Scottish Forestry Strategy (SFS) was launched on October 2006 and represents the overall policy framework for forestry in Scotland. See: http://www.forestry.gov.uk/sfs. 62 indicators are used to monitor implementation of SFS under the following themes: 1) Climate change, 2) Timber, 3) Business development, 4) Community development, 5) Access and health, 6) Environmental quality, and 7) Biodiversity. Of these, themes 4-6 are most relevant to the social aspects of forestry (See Section 2 for details of those indicators of most relevance.) (The Scottish... 2006).

\section{Scotland Land Use Strategy}

Scotland's first Land Use Strategy was established in March 2011. The strategy has three objectives (Land Use Strategy 2011):

- Objective 1: Land-based businesses working with nature to contribute more to Scotland's prosperity.

- Objective 2: Responsible stewardship of Scotland's natural resources delivering more benefits to Scotland's people.

- Objective 3: Urban and rural communities better connected to the land, with more people enjoying the land and positively influencing land use. 


\section{Scottish Biodiversity Strategy}

The Scottish Biodiversity Strategy "It's In Your Hands" was published in 2004 , and sets out a 25-year vision and framework for action for Scotland's biodiversity, strongly focused round the relationship between biodiversity and people. The aim of the Strategy is "to conserve biodiversity for the health, enjoyment and well-being of the people of Scotland now and in the future." It provides a foundation for Scotland's contribution to the UK's obligations under the international Convention on Biological Diversity (CBD), as well as the Scottish Government's commitment to sustainable development, and the statutory duty on public bodies in Scotland to conserve biodiversity under the Nature Conservation (Scotland) Act 2004. See: http://www.scotland.gov.uk/ Publications/2007/10/08091435/1 (Scotland's Biodiversity... 2004).

\subsubsection{Recreation and tourism indicators used}

\section{Scottish Forestry Strategy: Social indicators}

The indicators most relevant to the social aspects of forestry are listed below. They are grouped under three of the seven themes in the SFS: Community development, Access and health, and Environmental quality. The source of the data is given in brackets if known.

Theme 4: Community development

- Number of schools involved in woodland based learning activities.

- Number of community groups involved in owning or managing woodland (The most recent measurement by Forest Research (Stewart and Edwards 2013)).

- Number of schools providing vocational courses that include forestry related skills (Measurement by Lantra).

- Proportion of adults and/or family members who attended an organised learning activity or event linked with Scottish woodlands in the previous 12 months (Scottish Public Opinion of Forestry Survey. Forestry Commission. Biennial).

- Proportion of adults who have heard or read about Scottish woodlands in the previous 12 months (Scottish Public Opinion of Forestry Survey. Forestry Commission. Biennial).

- Number of land parcels sold or leased under the National Forest Land Scheme (Forest Enterprise Scotland Estates Team).

- Area of land parcels sold or leased under the National Forest Land Scheme (Forest Enterprise Scotland Estates Team). 
- Independent satisfaction rating of community partnerships on the national forest estate (Surveys conducted by the Community Woodland Association).

Theme 5: Access and health

- Proportion of the population with accessible woodland greater than 2 ha within $500 \mathrm{~m}$ of their home (The Woodland Trust.Triennial. Spatial and physical data is collected via a survey of local authorities and other woodland owners and managers which is collated in the Woods for People inventory).

- Proportion of the population with accessible woodland greater than 20ha within $4 \mathrm{~km}$ of their home (The Woodland Trust.Triennial. Spatial and physical data is collected via a survey of local authorities and other woodland owners and managers which is collated in the Woods for People inventory).

- Proportion of adults (16+ years) who visited woodland in previous 12 months (Scottish Public Opinion of Forestry Survey.Forestry Commission. Biennial).

- Number of visits to national forests (All Forests Survey.Forestry Commission. Baseline established over 3 year period concluding in 2006/7. It is undecided whether a repeat survey will be undertaken.).

- Number and length of core paths in woodlands.

- Proportion of visitors satisfied with woodland recreation provision (Scottish Public Opinion of Forestry Survey.Forestry Commission. Biennial).

- Proportion of people who used woodland, forest or tree covered park for exercise at least twice per week in the last four weeks (Scottish Health Survey, run by Scottish Government. In future the data should come from the Scottish Recreation Survey.).

- Number of volunteer days associated with woodland activity (Forest Research Valuation of the economic and social benefits of forestry for people in Scotland. (Edwards et al. 2009)). 
Theme 6: Environmental quality (cultural heritage and landscape)

- Proportion of woodlands covered by approved forest plans in areas designated for their landscapes (Forestry Commission Scotland provide data on forest plans; Scottish Natural Heritage provide data on national Scenic Areas).

- Number of current management plans for scheduled monuments in forests on the National Forest Estate (Forest Enterprise Scotland).

- Number of monuments in forests protected under a current forest management plan or agreement (National Inventory of Woodlands and Trees (NIWT) dataset, Forestry Commission Scotland).

\section{Scotland Land Use Strategy}

The strategy is currently developing indicators to monitor and measure progress towards meeting these objectives. See: http://scotland.gov.uk/ Publications/2012/06/4649/5. The proposed indicators of relevance to the social aspects of forestry are (Land Use Strategy 2011):

- (Obj 2 \& 3) People's interest and engagement in the stewardship of nature (Possible indicators include data on volunteering in natural heritage conservation or membership of biodiversity NGOs in Scotland).

- (Obj 3) People enjoy the land around them (Possible indicators include the use made of local green space and visits to the outdoors, e.g. the Scottish Recreation Survey).

- (Obj 3) People and communities take an active role in determining land use (Possible indicators might include data on activity in community led initiatives or land-based projects in the Climate Challenge Fund).

\section{Scottish Biodiversity Strategy}

A set of Scottish biodiversity indicators provide information to assess progress towards the achievement of the objectives of the Strategy. See: http://www.scotland.gov.uk/Publications/2007/10/08091435/2 (Scotland's Biodiversity Indicators... 2007).

There are 17 State indicators - and of particular relevance also 5 Engagement indicators as follows:

- E1: Attitudes to biodiversity (A representative sample of the Scottish population was surveyed in 2007 on behalf of Scottish Natural Heritage (SNH) and asked: How interested are you in Scotland's biodiversity? How relevant is Scotland's biodiversity to you? How concerned are you about the loss of biodiversity in Scotland?). 
- E2: Extent and composition of green space (Percentage of total settlement area covered by green space policies).

- E3: Visits to the outdoors (Measured through the Scottish Recreation Survey - see below. The indicator measures the percentage of participants in the survey that answered "yes" to the question "Have you made any leisure visits to the outdoors in Scotland in the last 12 months?").

- E4: Involvement in biodiversity conversation (Baseline information from a survey of 204 volunteer involving organisations carried out in $2005 / 2006$. It provides data on numbers of volunteers, hours volunteered and types of activity undertaken.).

- E5: Membership of biodiversity NGOs (Scottish membership of eight biodiversity NGOs, selected to include larger "membership based" NGOs working at a national level for the conservation of habitats and species across a number of biodiversity interests. Organisations were contacted in May 2007.).

\subsubsection{Monitoring and reporting of recreation and tourism indicators - Forestry Commission Recreation Statistics}

The Forestry Commission has conducted various surveys (some in collaboration with other agencies) to determine how the national forest estate contributes to people's lives. In particular, much work has been done on obtaining information about recreational use of forests: See: http://www. forestry.gov.uk/forestry/ahen-5gcdvl_(Recreation Statistics 2013).

\section{All Forests Monitoring (http://www.forestry.gov.uk/forestry/infd-5wcmr4)}

Surveys have been carried out to provide accurate profile and count data on visitors to all Forestry Commission woodland in Wales and Scotland. In 2002, the Forestry Commission developed a new visitor monitoring system to provide more accurate estimates of the number of visits to FC woodland, whilst continuing to gather information regarding the profile of visitors to the whole of the Commission estate. Visitors were surveyed and counted at all types of woodland, rather than concentrating on our main sites. The All Forests Monitoring system has been adopted in Wales and Scotland, with surveying starting in 2004. The Scotland All Forests survey covered five Forest Districts in each round, to give complete coverage by the end of 3 years in 2007. Interim reports were produced after each year of surveying. The results of all three years of fieldwork are presented together in a final report (All Forests Visitor... 2008). 
Quality of Experience

(http://www.forestry.gov.uk/forestry/infd-5wwjpt)

A new methodology, combining quantitative and qualitative survey methodologies was developed in early 2003, to measure the quality of visitor experience. To date around 50 on-site surveys have been conducted on FC sites (including some of the same site in different years) (Quality of... 2013).

\section{Forest Visitor Surveys and Counts}

(http://www.forestry.gov.uk/forestry/infd-5pgazz)

Local surveys aimed at providing forest managers with information on visitor profiles and numbers. Visitor surveys are carried out at a number of Forestry Commission sites each year. The findings are summarised in a single report published each year. More detailed reports for around 50 individual surveys are also available from over the last 12 years (Forest Visitor... 2013).

\section{General Visitor Surveys}

\section{(http://www.forestry.gov.uk/forestry/INFD-5ZYLCR)}

National visitor and recreation surveys are conducted in England, Scotland and Wales that include questions on visits to forests and woodland (for example, UK/GB Day Visits Survey). Those for Scotland are outlined below.

A Scottish Recreation Survey began in 2003. Sponsored by Scottish Natural Heritage (SNH) and the Forestry Commission, the survey collects information about visits to the outdoors for leisure and recreation (see below).

Visit Scotland ran a Scotland Visitor Survey in 2011 and 2012, which gains insight into visitor's expectations of their holiday in Scotland and what they do on it. Prior to this, Visit Scotland ran a Visitor Experience Survey.

The Forestry Commission joined with Highlands \& Islands Enterprise in sponsoring the Highland Visitor Survey 2002-03, which provides information about visitors and their visit to the area.

At Great Britain level, Day Visits Surveys were carried out in 1994, 1996, 1998 and 2002-03, for a consortium of government departments and agencies interested in tourism and recreation. The surveys provided estimates of the total number of leisure day visits from home to towns, countryside and seaside in Great Britain (England, Scotland, and Wales). They also gave the demographic profile of visitors and attributes of the visits such as duration and distance. Trips to woodland were identified by the surveys. See: http://www.forestry.gov.uk/forestry/INFD-5ZYLCR (General Visitor... 2013). 


\section{Forestry Commission Public Opinion of Forestry (POF) Surveys}

The biennial household-based Public Opinion of Forestry survey measures the opinions of the public to forestry and forestry-related issues. The scope of the survey was increased in 2003 to provide more detailed reports for each country. Reports from surveys conducted since 1999 can be downloaded from: http://www.forestry.gov.uk/forestry/ infd-5zyl9w (Public Opinion... 2013).

The POF Scotland 2011 survey includes relevant sections on a) Woodland recreation and b) Health and wellbeing. The following relevant measures are used:

- 7.1: Latent demand for woodland visits (Respondents were asked to state how often they would like to visit woodlands and the outdoors in the next 12 months).

- 7.2: Visits to woodland (Respondents were asked how often they had visited forests or woodlands for walks, picnics or other recreation in the last few years).

- 7.3: Frequency of woodland visits (Respondents were asked whether they had visited woodlands several times a week, several times a month, about once a month, less often, never. They did this for summer and winter.).

- 7.4: Type of woodland visited (Respondents were asked to distinguish between visits to "woodlands in the countryside" and "woodlands in and around towns)".

- 7.5: Reasons for not visiting woodland (Respondents who had not visited woodlands in the last few years were asked about their main reason for not visiting, and given a choice from eight categories of reason).

- 7.6: Woodland recreation opportunities (Respondents to the 2011 survey were asked to rate the woodland recreation opportunities, both in their local area and in Scotland as a whole, on a scale from very good to very poor).

- 7.7: Woodland learning activities (Respondents were asked whether they, or any member of their family, had attended any organised learning activities or events to do with woodland or forests within the last 12 months.).

- 8.1: Health in woodlands (Those who had visited forests or woodlands in the last few years, were asked to state on a scale of 1 to 10 how healthy they generally feel (where 1 denotes poor health and 10 denotes good health). They were then asked to rate, on the same 
scale, how healthy they generally feel when spending time outdoors in woodlands.).

- 8.2: Aspects of health in woodland (Respondents who had visited forests or woodland in the last few years were also asked what aspects of health and wellbeing they felt they benefited from when visiting woodlands and the outdoors as follows):

a) Physical Health: through increased exercise and physical activity.

b) Mental Health: through relaxation, stress-relief and improved mood.

c) Social Health and Wellbeing: through meeting other people/spending time with people and/or talking with family and friends.

\subsubsection{Monitoring and reporting of recreation and tourism indicators - Scottish Recreation Survey}

Scottish Natural Heritage ( $\mathrm{SNH}$ ) measures the levels of participation in walking and other outdoor recreational activities each year to support the achievement of Scottish Government policy. The Scottish Recreation Survey (ScRS), which was piloted in 2002 and ran from 2003 to 2013, was the established vehicle for gathering this information. It was commissioned by SNH with support from its survey partner, Forestry Commission Scotland (FCS). Each year, the study was undertaken through the monthly inclusion of a set of questions in the Scottish Opinion Survey, the consumer omnibus survey operated by TNS. This methodology ensured that a representative sample of around 1,000 members of the Scottish adult population (aged 16 years and over) was interviewed each month. While some questions were inserted into the survey every month, others were asked every second or third month, on a rotating basis.

The following indicators were measured in the survey:

- Visits to the outdoors for leisure and recreation in the last 12 months

- Frequency of outdoor visits in the last 12 months

- Reasons for not visiting the outdoors in the last 12 months

- Volume of visits to the outdoors in the four weeks prior to interview

- Estimate of total volume of visits (in the previous year)

- Activities undertaken on visits to the outdoors

- Location of outdoor recreation visits

- Path use and waymarking

- Details of visit 
- Areas visited in Scotland

- Party composition during outdoor recreation visits

- Expenditure on visit

- Awareness of outdoor access legislation and the Scottish Outdoor Access Code

- Problems with access during outdoor recreation visits.

The annual reports are available on the SNH website: http://www.snh. gov.uk/land-and-sea/managing-recreation-and-access/increasingparticipation/measuring-participation/. An updated Technical Report published in 2010 is also available: http://www.snh.gov.uk/publicationsdata-and-research/publications/search-the-catalogue/publication-detail/ ?id=1465. The survey was completed in 2013 and will be replaced by Scotland's Nature and People Survey (SPANS), which is likely to use a similar methodology and set of questions and indicators (Measuring Participation 2013).

\subsubsection{Monitoring and reporting of recreation and tourism indicators - Forestry for People study}

Between 2006 and 2008 a comprehensive valuation was carried out of the social and economic benefits of forestry, forests and woodlands in Scotland that are derived by the people of Scotland (Edwards et al. 2009: http://www.forestry.gov.uk/fr/INFD-6S8CSP.) The research was based upon a typology of seven themes as follows: a) employment and volunteering, b) contribution to the economy, c) recreation and accessibility, d) learning and education, e) health and well-being, f) culture and landscape, and g) community capacity. An indicator framework was developed as a basis for defining the scope of the project, reporting of headline findings, and to aid project management. Thirty quantitative indicators are covered by the report, which are distributed between the seven themes. The indicators for recreation and tourism were as follows:

- Number of visitors and visits to forests

- Percentage of visits involving different activities

- Non-market value of visits to forests

- Number and purpose of forest-related public events

- Public perceptions of forest-based recreation and accessibility. 


\subsubsection{References}

"All Forests Monitoring" (2013). Forestry Comission. Available at: http://www. forestry.gov.uk/forestry/infd-5wcmr4. [Cited 15th August 2013].

"All Forests Visitor Monitoring. Survey of visitors to FCS forests" (2008). Forestry Comission Scotland. Available at: http://www.forestry.gov.uk/pdf/AFS0407FINALREPORT. pdf/\$FILE/AFS0407FINALREPORT.pdf. [Cited 15th August 2013].

Edwards, D., Elliott, A., Hislop, M., Martin, S., Morris, J., O’Brien, L., Peace, A., Sarajevs, V., Serrand, M. and Valatin, G. (2009): "A Valuation of the Economic and Social Contribution of Forestry for People in Scotland." Forestry Commission Research Report 101, Forestry Commission Scotland, Edinburgh, 190 p. Available at: http://www. forestry.gov.uk/fr/INFD-6S8CSP. [Cited 31st July 2013].

FOREST EUROPE, UNECE, FAO (2011): "State of Europe's Forests 2011 report.” Available at: http://www.foresteurope.org/full_SoEF. [Cited 31st July 2013].

"Forest Visitor Surveys and Counts" (2013): Forestry Comission. Available at: http://www.forestry.gov.uk/forestry/infd-5pgazz. [Cited 15th August 2013].

"General Visitor Surveys" (2013): Forestry Comission. Available at: http://www.forestry.gov.uk/forestry/INFD-5ZYLCR. [Cited 15th August 2013].

"Land Use Strategy 2011." The Scottish Government. Available at: http://www. scotland.gov.uk/Publications/2011/03/17091927/0. [Cited 15th August 2013].

“Measuring progress: Sustainable development indicators 2010." Defra, Department for Environment, Food and Rural Affairs. Available at: http://sd.defra.gov.uk/ progress/national/annual-review/. [Cited 15th August 2013].

"National Indicators 2012." Scotland Performs. The Scottish Government. Available at: http://www.scotland.gov.uk/About/Performance/scotPerforms. [Cited 15th August 2013].

"Public Opinion of Forestry" (2013): Forestry Comission. Available at: http://www.forestry.gov.uk/forestry/infd-5zyl9w. [Cited 15th August 2013].

"Recreation Statistics" (2013): Available at: http://www.forestry.gov.uk/ forestry/ahen-5gcdvl. [Cited 15th August 2013].

"Scotland's Biodiversity Indicators - Summary document" (2007): The Scottish Government. Available at: http://www.scotland.gov.uk/Publications/2007/ 10/08091435/0. [Cited 15th August 2013].

"Scotland's Biodiversity: It's in Your Hands - A strategy for the conservation and enhancement of biodiversity in Scotland" (2004). The Scottish Government. Available at: http://www.scotland.gov.uk/Publications/2004/05/19366/37239. [Cited 15th August 2013].

"State of Europe's Forests 2011 - UK Report" (2010): Forestry Comission. Available at: http://www.forestry.gov.uk/forestry/infd-86hchq. [Cited 15th August 2013].

Stewart, A. and Edwards, D. (2013): "Number of community groups owning or managing woodland: Scottish Forestry Strategy Community Development Progress Indicator." Report to Forestry Commission Scotland January 2013.

"Sustainable Forest Management Indicators 2010" (2010). Forestry Comission. Available at: http://www.forestry.gov.uk/website/sfmindic2010.nsf/ LUContentsTop?openview\&RestrictToCategory=1. [Cited 15th August 2013].

"UK Indicators of Sustainable Forestry" (2002). Forestry Comission. Available at: http://www.forestry.gov.uk/website/pdf.nsf/pdf/fullsfi.pdf/\$FILE/fullsfi.pdf. [Cited 15th August 2013].

“The Scottish Forestry Strategy 2006." Forestry Comission. Available at: http://www.forestry.gov.uk/sfs. [Cited 15th August 2013]. 
"The Scottish Recreation Survey" (2013): Measuring Participation. Scottish Natural Heritage. Available at: http://www.snh.gov.uk/land-and-sea/managing-recreation-andaccess/increasing-participation/measuring-participation/. [Cited 15th August 2013].

"Qualitys of Experiences" (2013). Forestry Comission. Available at:

http://www.forestry.gov.uk/forestry/infd-5wwjpt. [Cited 15th August 2013].

\subsection{Sweden Country Report}

Peter Fredman (Mid-Sweden University / ETOUR) and Berit Svanqvist (National Board of Forestry)

\subsubsection{Introduction}

In Sweden there are several proposed initiatives to measure and monitor social values in the landscape, but no comprehensive nationwide system has been implemented so far. Since the social values include many aspects of the human-nature nexus, initiatives have been made by several agencies which only to some extent have been coordinated. Social values have also been studied in different research projects, but with little coordination. In 2007 the national research program "Friluftsliv i förändring" did a national survey on outdoor recreation participation which provided broad baseline data, and a follow-up survey to monitor the national policy on outdoor recreation in currently under consideration. A recommendation for the future is thus to better coordinate the efforts among the different stakeholders in order to provide an accepted and cost-efficient set of indicators which can be applied in a national (cross-sectional) monitoring system. Besides a presentation of proposed indicators, the following country report also includes a brief description of policies and statistics of importance for the implementation of social indicators in Sweden.

\subsubsection{Indicators of experience values in the landscape}

The Swedish National Board of Housing, Building and Planning has developed a system for mapping the supply and demand of experience values in the landscape (Landskapets upplevelsevärden... 2007). The outdoor landscape is defined once a person steps outside the door of their house, and emphasis is on nature used for everyday recreation. The purpose was to increase the awareness of "experience values" in the landscape in the work with the national environmental and public health goals. Another aim was to provide input to physical planning of urban 
proximate nature and green spaces in the municipalities. The project included a literature study, national demand and supply studies, and one case study in Västerås municipality.

In the national demand study respondents were asked to rank a large number of environmental qualities which were factor analyzed in order to indentify four groups of experience values; (i) An undisturbed diverse environment, (ii) Environmental features, (iii) Relaxation and recovery, and (iv) Safe and well managed. The following three indicators have then been suggested to monitor these experience values in the landscape:

Wellbeing: The proportion of the population which has less than 300 meters from their residence to a nature area which makes the individual feel physically and mentally well.

- Goal: Nature area providing opportunities for solitude, natural environment, recovery, safety within $300 \mathrm{~m}$ from residence.

- Data: Inventories of green areas with respect to physical qualities. Population surveys.

Proximity: Proportion of the population which has less than 300 meters from their residence to four nature- and/or culture areas.

- Goal: At least 4 out of 11 specified area types within $300 \mathrm{~m}$ from residence.

- Data: Maps, population statistics, inventories.

Visits: Number of visits in different types of areas, for example parks, nature reserves, cultural areas and facilities.

- Goal: To increase number of visits.

- Data: Visitor monitoring (counting and surveys).

In addition to these indicators, the agency suggests a fourth indicator to monitor the supply of nature in the proximity of schools. This indicator is suggested to measure the proportion of schools which has at least one nature area within 100 meters.

\subsubsection{Identification of forests with high social values}

The Swedish National Board of Forestry has developed a system for identification of forests with high social values (Skogsstyrelsen 2011) based on the approach for inventories of green wedges in the Stockholm 
region (see below). The purpose is to provide a uniform identification of forests with high social values regardless of landownership to support the national forest policy. Knowledge of such social values will also provide important information for community planning, schools, health promotion, tourism and forestry. The identification is based on local knowledge, existing data and field visits.

Three different indicators (criteria) are used to identify forests with high social values in Sweden:

Accessibility: The forest should be accessible for recreation, or accessible with simple means. Distance is an important aspect of this indicator, but also the time context (i.e. weekdays vs. holidays).

Quality: The forest should have qualities providing high outdoor recreation values. Such qualities include; wilderness/mystic, forest feeling, freedom, diversity/learning, culture, activity/challenge, and service/social. Since preferences differ among people, a diversity of qualities is preferred.

Use: High social values should apply to many people, both local and visitors. The frequency of use will differ between different sites depending on population density, geography, season, recreation opportunities and experience values.

Data used to monitor forests with high social values includes (i) local knowledge, (ii) secondary data, and (iii) field visits. Local knowledge involves both the staff doing the inventory as well as external knowledge. Secondary data can be from many different sources, for example municipality plans, regional plans, national inventories, local organizations and authorities. Field visits are done when local knowledge and secondary data are not sufficient for an appropriate judgment.

Special emphasis is given to urban proximate forests (within 500 meters from urban area), and such forests are considered of high social value unless they are directly unsuitable for recreation. Special emphasis is also given to forests in the proximity of second homes, schools, health care facilities, and frequently visited places (e.g. beaches, lookout points, rest areas, trails, golf courses and tourism infrastructure). A nationwide inventory of forests with high social values was started 2010, but has currently been put on hold. During year 2013 the Swedish National Board of Forestry is undertaking a review of current knowledge on social values in forests and will analyze the needs for further actions. 


\subsubsection{Inventory of urban proximate green wedges}

Given the increasing urbanization of the Swedish society, particular interest has been on promoting green spaces in the larger cities. As a consequence, the regional planning office of Stockholm has launched the concept of green wedges (Ståhle 2000, Lundh Malmros and Tönnerfors 2001). The basic idea is to promote green areas with high social values stretching from the more rural periphery into the city centre. Seven indicators have been developed with help from local planners, managers and focus groups:

- Untouched green space: Old-growth forest, low noise levels, 250 meters from roads and facilities.

- Woodland harmony: Continuous forest area, low noise level, 250 meters from roads and facilities.

- Open views and open landscapes: Lakes, viewpoints and open landscapes.

- Biodiversity and lessons from nature: Biodiversity, pastures, wetlands, low noise level, trails, visitor centers.

- Cultural history and living environment: Open farmland, cultural heritage objects.

- Activities and challenges: Trails, tracks, facilities, outdoor pools, lakes, fitness centers.

- Facilities and meeting places: Restrooms, dressing-rooms, visitor centers, cafeteria, information, fitness centers.

According to Åkerlund (2011) the compilation of social values in the green wedges is currently applied in a wide range of contexts including regional planning, municipal comprehensive planning, information on recreation and tourist facilities, and forest management.

\subsubsection{Indicators of social values in the environmental quality objectives}

Eight out of the 16 national environmental quality objectives in Sweden address social values, for example a balanced marine environment, flourishing coastal areas and archipelagos, stainable forests, a magnificent mountain landscape, and a good built environment. Several of the objectives emphasize the importance of urban proximate environments for outdoor recreation opportunities. In 2012 the Swedish Environmental Agency proposed 22 indicators to monitor the national societal shift towards the decided objectives (Brolinson and Palm 2012). It was, how- 
ever, concluded that the limited time for the project was an obstacle to produce indicators within some areas, among them outdoor activities. Hence, during 2013 the Swedish Environmental Agency will develop indicators to monitor outdoor recreation in the environmental objectives which are to be harmonized with the objectives in the Swedish outdoor recreation policy (see below).

\subsubsection{The National Inventory of the Swedish Landscape (NILS)}

Launched in 2007, the National Inventory of the Swedish Landscape (NILS) was extended to cover also urban green space (Hedblom et al. 2011). This included methods for environmental monitoring of green area quality in urban - and urban proximate areas, particularly with regard to their impact on biodiversity and human perception (experience). The number of green space needed to obtain a statistically sustainable amount of data to describe the quality (biodiversity and perception) to green areas in the city and peri-urban areas have been presented, and a method for measuring human perception of open spaces in the city and the periurban areas suggested (Hedblom and Gyllin, 2009). However, also in this case a main conclusion is that further development of methods is needed. This is partly because perceived experience values are hard to measure in a standardized way, and because urban areas grow both inwards and outwards which imply that green areas will disappear and new ones will emerge, which requires additional method development.

\subsubsection{The Swedish outdoor recreation policy}

In December 2010 the Swedish parliament voted for the government bill "Framtidens friluftsliv," The Future of Outdoor Recreation (Prop. 2009/10:238) and Sweden got an outdoor recreation policy at the national level for the first time ever. The parliament did, however, request measurable objectives to be developed for each of the ten policy areas. These objectives were reported to the Ministry of Environment by the Environmental protection Agency in March 2012 (Naturvårdsverket 2012). Below is a summary of the ten policy areas and proposed measurable objectives:

- Accessible nature: There is ample opportunity for people to enjoy the countryside and spend time outdoors, which satisfies people's varying needs. Areas with good accessibility are indicated, known 
and appreciated and are managed on a long term basis. Accessibility has a high priority in all planning, information and the management of the countryside and outdoor recreation.

- Strong commitment and cooperation: More and more people are spending an increasing amount of time pursuing outdoor recreational activities. There are established structures for dialogue and the coordination of outdoor recreation locally, regionally and nationally.

- Allemansrätten forms the basis of outdoor recreation: The Common Right of Access to Private Land (Allemansrätten) is strongly supported by the general public, landowners, clubs and associations and businesses.

- Access to nature for outdoor recreation: Urban planning and land use takes into account the need for access to attractive areas of the countryside.

- Attractive natural areas close to urban centres: The population has access to the countryside offering major environmental values in terms of recreation, nature and culture close to urban centres.

- Sustainable regional growth: Outdoor recreation, nature and cultural tourism contribute to strong and sustainable rural development and regional growth. The sector for natural and cultural tourism is established. Quality, accessibility and safety are key features when describing outdoor recreation. Business activities assume a holistic approach and take into account ecological and social values.

- Protected areas as a resource for outdoor recreation: There are protected areas which are of value for outdoor recreation, they are managed and cared to foster outdoor activities and recreation.

- Valuable outdoor recreation at school: Nursery schools, primary schools and after-school recreation centres often conduct regular outdoor activities and educational activities in the countryside which is of an excellent pedagogical quality within the framework of the nursery school and the school's policy documents.

- Outdoor recreation for the good health of the people: An increasing proportion of the population regularly conducts physical activities in the countryside for improved public health.

- Good knowledge of outdoor recreation: Established research and statistics are available regarding outdoor recreation activities which are based on the subject's diversity and its interdisciplinary nature; the information is also long-term and based on the needs of operators within the field of outdoor recreation. Authorities, organisations, municipalities, land owners and businesses have 
excellent knowledge and skills relating to issues that concern outdoor recreation activities and natural/cultural tourism.

The Environmental Protection Agency has identified several issues to be resolved if the objectives of the outdoor recreation policy is to be complied. Among these are financial resources for the implementation of the policy, the opportunities to conduct research and collect statistics to follow-up of the objectives, coordination at regional level and clarification of the objectives with respect to their relationship to environmental objectives. The process of developing the objectives was very much an exercise of coordination and cooperation as more than 15 different public agencies, NGOs and universities were involved, reflecting the diversity of outdoor recreation stakeholders. In December 2012 the government writ "Mål för friluftslivspolitiken" (Goals for the Outdoor Recreation Policy) was published which points out the future of the Swedish outdoor recreation policy more or less following the intentions in the above mentioned ten policy areas (Writ. 2012/13:51).

\subsubsection{Social values in policies for forestry, protected areas and public health}

In addition to the abovementioned policies, social values in the natureand culture landscape are also to some extent included in policies concerning forestry, protected areas and public health.

Swedish forests provide many different benefits to society. The Swedish forest policy has two equal objectives - wood production and environmental protection. Social values are considered, but lack more specific objectives. The proposition "En skogspolitik i takt med tiden" (Prop. 2007/08:108) explicitly states that social and esthetic values should be protected in Swedish forests. Social values are important for the general public and forest owners should increase their knowledge how to consider such values in forest management. Social values are also particularly important for people living in rural areas through outdoor recreation and associated business opportunities.

Policies regarding protected areas have increasingly emphasized social values during the last decade. Following a governmental writ in 2001 (Writ. 2001/02:173), the Swedish Environmental Protection Agency launched the "Protect, Preserve, Present" program for a better utilization and management of protected areas. Two out of six focus areas concerns outdoor recreation, tourism and information. Among the goals of the program (to be achieved by year 2015) are: (i) Areas of high values for visi- 
tors are identified and accessible; (ii) Methods for visitor monitoring in national parks (and areas of similar importance for recreation) are established and data is collected on a continuous basis; and (iii) Information on protected areas is available on line. In the proposition "Hållbart skydd av naturområden" from 2008 it is further stated that protected areas should be managed so they are accessible and a resource for regional development, tourism and public health (Prop. 2008/09:214).

The national Swedish public health policy also to some extent concerns social dimensions of outdoor recreation. In the proposition "En förnyad folkhälsopolitik" from 2007 it is emphasized that physical activity is important to safeguard a positive development of public health (Prop. 2007/08:110).

\subsubsection{Environmental monitoring and assessment}

The Swedish University of Agricultural Sciences (SLU) has the task to also conduct environmental monitoring and assessment (EMA). The aim is to monitor the country's forests, agricultural landscapes, lakes, watercourses and species in order to analyze environmental trends, such as for example interpreting and understanding changes that may result from a warmer climate (Sveriges lantbruksuniversitet...2013). The program is organized around Sweden's environmental objectives, and will accordingly also be of relevance to social values.

\subsubsection{Statistics and research-based data on social values}

- Statistics Sweden collects information on outdoor recreation participation as part of the national census - "Undersökningar av levnadsförhållanden, ULF” (Statistics Sweden 2004 and 2009). This has been done in 1976, 1982-83, 1990-91, 1999, 2006-07 with a sample of approximately 7,000 each time. These surveys provide participation data for a small selection of activities over time, i.e. walking, forest hiking, gardening, outdoor swimming, boating, fishing, backpacking and hunting. A new survey is planned for year 2013-14.

- In 2009 the Swedish Environmental Protection Agency proposed a national program for outdoor recreation statistics (Naturvårdsverket 2009). The basic idea was to suggest a longitudinal program which covers data at different spatial levels to meet the needs of different stakeholders (Yuan and Fredman 2008). The program includes a national survey to measure outdoor recreation participation and trends, in-depth studies on specific topics (e.g. access, motivations, 
constraints, economics), and on-site visitor monitoring in selected areas. The program has so far not been implemented.

- "Friluftsliv i förändring" is an interdisciplinary, national research program for the study of outdoor recreation and nature-based tourism in Sweden (Friluftsliv i förändring 2013). The program has used case studies in combination with a national/regional postal and follow-up Internet inquiry to provide information on participation in outdoor recreational activities as well as associated motivations, constraints, economic and social factors (Fredman et al. 2008). The postal survey included a national sample of 4,700 and regional oversampling in three regions (two urban proximate and one coastal) of 2,300. Over 40 different outdoor recreation activities were analyzed and the survey was aimed to provide based-line data for future follow-up studies

- Since nature is considered to be of outmost importance for Swedish tourism with a significant impact on the international image of the country, the European Tourism Research Institute (Etour) has provided an overview of the nature-based tourism sector (Fredman et al. 2009). The aims of the report was to describe nature tourism from both tourism provider and consumer points of view, to propose a definition of nature tourism, to examine present tourism statistics and other sources of knowledge from a Swedish nature tourism perspective, and to present suggestions on how nature tourism in Sweden can be better measured and quantified. In the results from this work it is acknowledged that there is a lack of definitions, statistics and coordination in this sector. Nature-based tourism ought to be measured from four main perspectives; consumer surveys (national and international), a supply survey and systematic on site visitor surveys. As a follow up to these recommendations, Etour has made a national inventory of nature-based tourism supply including approximately 2,000 companies which will be subject to further analyses in the coming years. 


\subsubsection{References}

Brolinson, H and Palm, V. (2012): "Förslag till indikatorer för uppföljning av generationsmålet. Underlag till den fördjupade utvärderingen av miljömålen 2012." Rapport 6503, Naturvårdsverket, Stockholm.

Fredman, P., Karlsson, S-E, Romild, U. and Sandell, K. (red.) (2008): "Vilka är ute i naturen? Delresultat från en nationell enkät om friluftsliv och naturturism i Sverige." Forskningsprogrammet Friluftsliv i förändring, rapport nr. 1. Available at: www.friluftsforskning.se. [Cited 30th July 2013].

Fredman, P., Wall Reinius, S. and Lundberg, C. (2009): “Turism i natur. Definitioner, omfattning, statistik." Turismforskningsinstitutet ETOUR, Mittuniversitetet, Östersund. Rapport R2009:23, $126 \mathrm{p}$.

"Friluftsliv i förändring” (2013). Available at: http://www.friluftsforskning.se/. [Cited 19th July 2013].

Hedblom, M., Caruso, A., Green., M and Ode, Å. (2011): “Grönytor i tätorter - metoder att följa utvecklingen av upplevelsevärden och biologisk mångfald." Rapport 6411, Naturvårdsverket, Stockholm.

Hedblom and Gyllin (2009): "Övervakning av biologisk mångfald och friluftsliv i tätorter - en metod studie." Rapport 5974. ISBN 978-91-620-5974-3.

"Landskapets upplevelsevärden - vilka är de och var finns de?" (2007). Boverket, Karlskrona. Available at: http://www.boverket.se/Global/Webbokhandel/ Dokument/2007/landskapets_upplevelsevarden.pdf. [Cited 22nd July 2013].

Lundh Malmros, B. and Tönnerfors E. (2001): “Upplevelsevärden, sociala kvaliteter i den regionala grönstrukturen." Regionplane- och trafikkontoret, Stockholm, Rapport 4.

Naturvårdsverket (2009): "Statistikprogram för friluftsliv - ett förslag." Rapport 5975, Naturvårdsverket, Stockholm.

Naturvårdsverket (2012): "Förslag till mål för friluftspolitiken. Redovisning av ett regeringsuppdrag." Rapport 6476.

Prop. 2009/10:238. "Framtidens friluftsliv." Regeringskansliet, Stockholm.

Prop. 2007/08:108. "En skogspolitik i takt med tiden." Regeringskansliet, Stockholm. Prop. 2007/08:110. "En förnyad folkhälsopolitik." Regeringskansliet, Stockholm. Prop. 2008/09:214. "Hållbart skydd av naturområden." Regeringskansliet, Stockholm. Skogsstyrelsen (2011): "Rutin - Identifiering av skogar med höga sociala värden." Statistics Sweden (2004): “Fritid 1976-2002. Levnadsförhållanden." Rapport nr. 103. Statistiska Centralbyrån, Stockholm.

Statistics Sweden (2009): “Fritid 2006-07. Levnadsförhållanden.” Rapport nr. 118. Statistiska Centralbyrån, Stockholm.

Ståhle, A. (2000): "Sociotop som redskap i grönområdesplanering." Stockholms stadsbyggnadskontor, rapport 2000:4: och Lundh Malmros, B. \& Tönnerfors E. (2001): "Upplevelsevärden, Sociala kvaliteter i den regionala grönstrukturen." Regionplane- och trafikkontoret, Stockholm, Rapport 4.

Sveriges lantbruksuniversitet, Swedish University of Agricultural Sciences (2013). Available at: http://www.slu.se/environment/. [Cited 19th July 2013].

Yuan, M. and Fredman, P. (2008): "A Call for a Broad Spatial Under-standing of Outdoor Recreation Use." In: Raschi, A. and Trampeti, S. (eds.) "Management for protection and sustainable development. Proceedings of the Fourth International Conference on Monitoring and Management of Visitor Flows in Recreational and Protected Areas." Montecatini Terme, Italy, pp. 14-19 October, 2008. 
Writ. 2001/02:173. "En samlad naturvårdspolitik." Regeringskansliet, Stockholm. Writ. 2012/13:51. “Mål för friluftspolitiken.” Regeringskansliet, Stockholm.

Åkerlund, U. (2011): “Stockholm's green wedges - Concepts, learning and collaboration on urban and peri-urban forestry." Experience paper for EUFAP Workshop on urban and peri-urban forestry, Brussels, 28 January 2011. 


\section{Appendix 2. FOREST EUROPE Indicator 6.10: "Accessibility for Recreation"}

David Edwards, Forest Research, UK

Analysis of data and country comments for "intensity of use"

1. This report analyses the data and comments provided by countries for the "intensity of use" component of FOREST EUROPE (Forest Europe) Indicator 6.10 ("Area of forest and other wooded land where public has right of access for recreational purposes and indication of intensity of use)". Its main sources are the "State of Europe's Forests" (SOEF) reports 2011 and 2007, and the individual country reports.

2. In the SOEF 2011 report, 15 countries provided estimates for "intensity of use" for the reporting year 2005. In SOEF 2007, 10 counties provided estimates for various reporting years (Table 32, p100).

3. Of the 15 countries that reported data for 2005 in SOEF 2011, ten appear to have provided data for numbers of visits to all forests in their respective countries: Czech Republic, Denmark, France, Germany, Ireland, Lithuania, Netherlands, Norway, Switzerland and UK. The figure for Czech Republic needs to be checked (see Appendix 2). Finland and Italy both provided figures for 2000, which in principle could have been used for 2005 if there are no clear reasons for significant changes in visit numbers since then. Likewise, Sweden could have included the figure of 339 million from SOEF 2007, unless this is now considered out of date.

4. Five countries (Croatia, Cyprus, Estonia, Russian Federation and Ukraine) provided estimates which only cover a small proportion of the forest area, typically National Parks. (In addition, Albania appears to have been able to provide such a figure based on data given in SOEF 2007, but no estimate was reported in SOEF 2011). In SOEF 2011, none of these five counties recorded the area of forest that the estimate relates to. Cyprus was the only country that did so in SOEF 2007 (although the figure of 158 ha looks too low).

5 . For nearly all countries, other assumptions were not made explicit in any of the SOEF reporting, in particular the age range of respondents, whether the definition of a visit deviated from the one given in the en- 
quiry, and whether the definition included visits made while staying away from home, visits by overseas tourists, and visits not considered leisure e.g. routine dog walking.

6 . The quality of the data from the next reporting round could be improved if the need to specify further information is made more explicit in the reporting form: a) the area of forest and other wooded land covered by the estimate, b) the definition of visits that was used, c) the primary data sources. Assuming countries provide this information, when this indicator is written up in SOEF 2015, it would be worth highlighting which estimates for "intensity of use" referred to subsets of total forest cover, and quoting this area in footnotes or the main text. Otherwise, the variations in intensity of use between countries are likely to be misinterpreted.

7. The SOEF reports and individual country reports do not give enough information on methods used to estimate number of visits as a basis for recommending improved approaches to be used across Europe. For this reason, it would be worth examining the primary sources. This would also allow existing figures to be checked, and some of the assumptions to be clarified.

8. Annex 1 gives a list of the primary sources used in the SOEF reporting and in other key secondary sources: COST E33, UNECE/FAO (2005), and SOSIN. Annex 2 collates and analyses the original data and comments from SOEF 2007 and 2011.

\subsection{Annex 1: Primary sources for data on "intensity of use"}

\subsubsection{Primary sources used in SOEF 2007 and 2011}

The full reports can be downloaded from: http://www.foresteurope. org/documents. It is not clear how to download the individual country reports for 2011 (I have copies due to my previous involvement with SOEF reporting). Those for 2007 can be downloaded from: http://www.unece.org/forests/fcp/reportingonsfm2007/quantitativeind icators.html.

Czech Republic:

- Surveys conducted by University of Prague. 
France:

- Enquête ONF - Université de Caen/LASAS, "Forêt et societé" 2004.

Germany:

- Elsasser P. (2001): "Der ökonomische Wert der Wälder in Deutschland für die Naherholung:" Eine "Benefit Function Transfer" Schätzung Zeitschrift für Umweltpolitik und Umweltrecht 24 (3), pp. 417-442.

- BMVEL Ref. 534 (2000): "Nationales Forstprogramm Deutschland Ein gesellschaftlicher Dialog zur Förderung nachhaltiger Waldbewirtschaftung im Rahmen einer Nachhaltigen Entwicklung 1999/2000."

Ireland:

- Fitzpatrick and associates report (See COST E33 refs below)

- Clinch, P. (1999): "The economics of Irish forestry." COFORD, Dublin, Ireland.

Italy:

- Croitoruo, Gatto, Merlo and Pairo in the volume edited by Merlo and Croitoru "Valuing Mediterranean Forests - Towards Total Economic Value," 2005, CABI Publishing.

Lithuania:

- Lietuvos gyventojų sociologinès apklausos svarbiausiais miškų ūkio klausimais bei respondentų nuomonès analizès atlikimas (Sociological survey of residents of Lithuania regarding main issues of forestry and analysis of results). Kaunas, 2006, 253 m. (manuscript).

Netherlands:

- TNS-NIPO, 1997, Dagelijks 750.000 bezoeken aan de bossen, ProBos vraagt financiering voor maatschappelijke functies, persbericht, http://www.tns-nipo.com/pages/nieuws-pers-vnipo.asp?file= persvannipo $\backslash$ bos.htm. 
Norway:

- Vågane, L. (2002): "Samordnet levekårsundersøkelse 2001 tverrsnittsundersøkelsen: dokumentasjonsrapport." Oslo: Statistisk Sentralbyrå. Norway.

- Houghen, H. C. (2005): “Samordnet levekårsundersøkelse 2004 tverrsnittsundersøkelsen: dokumentasjonsrapport." Oslo: Statistisk Sentralbyrå.

Sweden:

- Cairos Future (2005).

- National Institute of Statistics (SCB) 1987-1993.

Switzerland:

- SAEFL (2000): “The social demands on Swiss Forests.”

United Kingdom:

- Household recreation surveys.

- UK/GB Day Visits Surveys from 1994 to 2002/03, separate country surveys in later years, summarised in Forestry Statistics 2009 Table 6.1.

- Public Opinion of Forestry surveys.

\subsubsection{Primary sources used in COST E33}

See: Dehez, J., Colson, V., Mann, C. and Sievänen, T. (2008). State of art of recreation inventories in European countries. Chapter 3 in: Sievänen, et al. (eds). Forest Recreation Monitoring - a European Perspective. Working papers of the Finnish Forest Research Institute, 79. (The references below were taken from a draft version of Dehez et al.; not all of them are listed in the published version).

Denmark:

- Jensen F. S. (1998): “Forest Recreation in Denmark from the 1970's to the 1990's." The Research Series no. 26. Danish Forest and Landscape Research Institute, Horsholm, 166 p.

- Jensen, F. S. \& Koch, N. E. (1997): "Friluftsliv i skovene 1976/771993/94." Danish Forest and Landscape Research Institute, Hørsholm. The Research Series No. 20, 215 p. ISBN 87-89822-89-7. (In Danish). 
Finland:

- National Outdoor Recreation Demand and Supply Assessmentproject (LVVI).

- www.metla.fi/metinfo/monikaytto/lvvi/index-en.htm.

France:

- ONF (2004), Forêt et Société, Office National des Forêts, Paris.

- Peyron J. L., Harou P., Niedzwiedz A., Stenger A. (2002): "National survey on demand for recreation in French forests." Laboratoire d'Economie Forestière UMR ENGREF/INRA, Nancy.

Germany:

- Ellsasser P. (2001): "Der ökonomische Wert der Wälder in Deustchland für die Naherholung:" Eine"Benefit Function Tranfer" Schätzung. Zeitschrift für Umweltpolitik und Umweltrecht 24(3), pp. 417-442.

- Institut für Forstpolitik (1999): “Repräsentative Bevölkerungsbefragung in der BRD zu den gesellschaftlichen und politischen Bedingungen für die Entwicklung von Laubwäldern. Tabellenband." 85 p.

Switzerland:

- Zimmerman W., Franzen A., Wild Eck S., Hungerbühler A., (2000): "The Social demands on the Swiss Forest." Environmental Series no 309, Forest, Swiss Agency for the Environment, Forest and Landscape (SAEFL), $129 \mathrm{p}$.

- http://www.bafu.admin.ch/

Hungary:

- Survey on the public needs and market demands from forest land use, Institute of Forest Asset Management, University of West Hungary, Sopron, May 2006. 52p.

Ireland:

- Coillte - The Irish Sports Council (2005): "The Economic Value of Trails and Forest Recreation." Fitzpatrick Associate, 62p. 
Norway:

- Study of living condition 2004, Statistic Norway.

Netherlands:

- National Day Trip Survey 2001/2002, Statistics Netherlands.

\subsubsection{Primary sources used in UNECE/FAO (2005)}

See: UNECE/FAO 2005. European Forest Sector Outlook Study, 19602000-2020. Main Report. Geneva Timber and Forest Study Paper 20, FAO, Geneva (Table 19, page 106).

Austria:

- Aldrian, A., Bauer, A., Eberl, W., Rametsteiner, E., Sekot, W., Wagner, S., and Weiss, G., (2004): Austria country report, report for EC COST E30 Project.

Denmark:

- Helles, F., and Thorsen, B. J. (2004): Denmark country report, report for EC COST E30 Project.

Finland:

- Erkkonen, J., and Sievänen, T. (2003): Visitor information - surveys and countings in Finland, METLA, Finland: http://www.metla.fi/ metinfo/monikaytto/lvvi/index-en.htm.

Italy:

- Pettennela, D., Klohn, S., Brun, F., Carbone, F., Venzi, L., Cesaro, L., Ciccarese, L. (2004): Italy country report, report for EC COST E30 Project.

Portugal:

- Carvalho Mendes, A. M. S. (2004): Portugal country report, report for EC COST E30 Project. 
Switzerland:

- Baruffol, U., Baur, P., Dürrenmatt, R., Kammerhofer, A., Zimmermann, W., Schmithüsen, F. (2003): EU-project evaluating financing of forestry in Europe: Country report Switzerland, Swiss Federal Institute of Technology, Zürich, Switzerland.

\subsubsection{Social Indicators in Forestry - project, country reports (2012)}

- Estonia

- Finland

- Germany

- Russia

- Scotland

- Sweden. 


\begin{tabular}{|c|c|c|c|c|c|c|c|c|}
\hline \multirow[t]{2}{*}{ Country } & \multicolumn{3}{|c|}{$\begin{array}{l}\text { Annual number of visits } \\
\text { (million) }\end{array}$} & \multirow{2}{*}{$\begin{array}{l}\text { Comments related } \\
\text { to data, definitions, } \\
\text { etc. (SOEF 2011) }\end{array}$} & \multirow[t]{2}{*}{$\begin{array}{l}\text { Comments on trend(s) } \\
\text { (SOEF 2011) }\end{array}$} & \multirow[t]{2}{*}{$\begin{array}{l}\text { Data sources } \\
\text { (SOEF 2011) }\end{array}$} & \multirow[t]{2}{*}{$\begin{array}{l}\text { Comments (SOEF 2007)(and Data } \\
\text { (Table 32, p100)) }\end{array}$} & \multirow[t]{2}{*}{ Analysis } \\
\hline & 2005 & 2000 & 1990 & & & & & \\
\hline Albania & n.a. & n.a. & n.a. & & & & $\begin{array}{l}\text { Number of visits } 16.25(1,000) \text { and visitors in } \\
\text { forests: } 65.00(1,000 \text { persons), compiled from } \\
8,000.00 \text { ha. during all the } 2005 \text { year to three } \\
\text { National Parks, one Nature Monument and three } \\
\text { Managed Nature Reserves. [...] }\end{array}$ & $\begin{array}{l}\text { SOEF } 2007 \text { estimate limited to } \mathrm{Na}- \\
\text { tional Parks, etc. Unclear why the } \\
\text { number of visits is less than the } \\
\text { number of visitors }\end{array}$ \\
\hline Croatia & 2 & n.a. & n.a. & $\begin{array}{l}\text { Data only for num- } \\
\text { ber of sold tickets in } \\
\text { national parks. }\end{array}$ & & (various) & & Limited to National Parks. \\
\hline Cyprus & 1 & & & & & & $\begin{array}{l}\text { Number of visits: } 641.5 \text { ( } 1,000 \text { visits) compiled } \\
\text { from } 158.1 \text { ha. [...]. Data regarding intensity of use } \\
\text { were collected by the Department of Forests. }\end{array}$ & $\begin{array}{l}\text { SOEF } 2007 \text { suggests } 2005 \text { estimate is } \\
\text { limited to just } 158 \text { ha. }\end{array}$ \\
\hline $\begin{array}{l}\text { Czech } \\
\text { Republic }\end{array}$ & 216 & 241 & n.a. & & & $\begin{array}{l}\text { Annual report on the state } \\
\text { of forests and forestry, } \\
\text { Ministry of Agriculture, } \\
\text { Prague. High quality. Years } \\
2000 \text { and } 2005 \text {. Surveys } \\
\text { performed by the Univer- } \\
\text { sity of Prague. }\end{array}$ & $\begin{array}{l}\text { Number of visits } 20,400(1,000) \text { and visitors in } \\
\text { forests: } 20,400(1,000 \text { persons), compiled from } \\
2,647,000 \text { ha. } \\
(20.4 \text { million visits/year; } \\
2.0 \text { visits/person/year; } \\
\text { Compiled from 2,647,000 ha) }\end{array}$ & $\begin{array}{l}\text { SOEF } 2007 \text { comment (and main report } \\
\text { p.100) indicates the estimate should } \\
\text { be around } 20 \text { million, yet a figure of } \\
216 \text { million is given in SOEF } 2011 . \\
\text { Possible error by factor of } 10 ?\end{array}$ \\
\hline Denmark & 75 & 50 & n.a. & & & & $\begin{array}{l}\text { Number of visits } 50,000 \text { ( } 1,000 \text { visits) and visitors in } \\
\text { forests: i.d (1,000 persons), compiled from (?) ha } \\
\text { (50.0 million visits/year; } \\
9.2 \text { visits/person/year.) }\end{array}$ & $\begin{array}{l}\text { OK. } \\
\text { No figure for number of ha in SOEF } \\
2007 .\end{array}$ \\
\hline Estonia & 1 & & & $\begin{array}{l}\text { According to the } \\
\text { numeration of the } \\
\text { visitors only on the } \\
\text { recreational areas of } \\
\text { State Forest Man- } \\
\text { agement Centre }\end{array}$ & $\begin{array}{l}\text { Trend is increasing - } \\
650,000 \text { visits in 2006, } \\
820,000 \text { visits in 2007, } \\
790,000 \text { visits in 2008, } \\
995,000 \text { visits in 2009 }\end{array}$ & $\begin{array}{l}\text { Nature Management } \\
\text { department of the State } \\
\text { Forest Management } \\
\text { Centre - www.rmk.ee, } \\
\text { unpublished data. Medi- } \\
\text { um quality. 2003-2009. }\end{array}$ & & Restricted to State Forest. \\
\hline
\end{tabular}




\begin{tabular}{|c|c|c|c|c|c|c|c|c|}
\hline \multirow[t]{2}{*}{ Country } & \multicolumn{3}{|c|}{$\begin{array}{l}\text { Annual number of visits } \\
\text { (million) }\end{array}$} & \multirow{2}{*}{$\begin{array}{l}\text { Comments related } \\
\text { to data, definitions, } \\
\text { etc. (SOEF 2011) }\end{array}$} & \multirow[t]{2}{*}{$\begin{array}{l}\text { Comments on trend(s) } \\
\text { (SOEF 2011) }\end{array}$} & \multirow[t]{2}{*}{$\begin{array}{l}\text { Data sources } \\
\text { (SOEF 2011) }\end{array}$} & \multirow[t]{2}{*}{$\begin{array}{l}\text { Comments (SOEF 2007)(and Data } \\
\text { (Table 32, p100)) }\end{array}$} & \multirow[t]{2}{*}{ Analysis } \\
\hline & 2005 & 2000 & 1990 & & & & & \\
\hline Finland & n.a. & 629 & n.a. & $\begin{array}{l}\text { Visits of Finns in any } \\
\text { forest for recreation } \\
\text { purposes }\end{array}$ & & $\begin{array}{l}\text { Tuija Sievänen, Finnish } \\
\text { Forest Research Institute. } \\
\text { High quality. }\end{array}$ & $\begin{array}{l}\text { Number of visits } 1,770 \text { ( } 1,000 \text { visits) and visitors in } \\
\text { forests: } n . a .(1,000 \text { persons), compiled from } 896,000 \\
\text { ha. [...]Information on intensity of use bases on the } \\
\text { visitor statistics compiled by Metsähallitus. } \\
\text { (1.8 million visits/year; } \\
0.2 \text { visits/person/year; } \\
\text { On state land only) }\end{array}$ & $\begin{array}{l}\text { The estimate of } 629 \text { given for yr2000 } \\
\text { in SOEF } 2011 \text { could perhaps have } \\
\text { been used for } 2005 \text { as well (assuming } \\
\text { no evidence to suggest significant } \\
\text { changes) }\end{array}$ \\
\hline France & 500 & n.a. & n.a. & $\begin{array}{l}\text { The only available } \\
\text { data on the intensity } \\
\text { of use comes from } \\
\text { an enquiry (see data } \\
\text { sources). Updated } \\
\text { data should be } \\
\text { available in } 2011 . \\
\text { According to the } \\
\text { same source, the } \\
\text { number of visitors in } \\
\text { the French forests is } \\
\text { close to } 35 \text { million } \\
\text { people per year. }\end{array}$ & & $\begin{array}{l}\text { Enquête ONF - Université } \\
\text { de Caen/LASAS, "Forêt et } \\
\text { societé" 2004. Medium } \\
\text { quality. L'étude porte sur } \\
\text { toutes les forêts françai- } \\
\text { ses. }\end{array}$ & $\begin{array}{l}\text { Number of household visits } 441,000 \text { ( } 1,000 \text { visits) } \\
\text { and individual visits in forests: } 1,010,000 \text { (1,000 } \\
\text { persons), which represents } 30,654 \text { (1,000 persons) } \\
\text { and } 54 \% \text { of the population, compiled from } \\
15,400,000 \text { ha } \\
(441.0 \text { million visits/year; } \\
7.3 \text { visits/person/year; } \\
\text { Compiled from } 15,400,000 \text { ha.) }\end{array}$ & $\begin{array}{l}\text { OK. } \\
\text { It isn't clear how the figure of } 500 \\
\text { million was derived. Possibly this is } \\
\text { rounded up from } 441 \text { million reported } \\
\text { in SOEF } 2007 \text { (which also suggests } \\
\text { visits could be up to } 1,000 \text { million). }\end{array}$ \\
\hline Germany & $\begin{array}{l}1,50 \\
0\end{array}$ & 1,500 & n.a. & Study P. Elsasser & & $\begin{array}{l}\text { BMVEL Ref. } 534 \text { 2000: } \\
\text { Nationales Forstpro- } \\
\text { gramm Deutschland Ein } \\
\text { gesellschaftlicher Dialog } \\
\text { zur Förderung nachhalti- } \\
\text { ger Waldbewirtschaftung } \\
\text { im Rahmen einer Nach- } \\
\text { haltigen Entwicklung } \\
\text { 1999/2000. Year: 1995. } \\
\text { ELSASSER, P. (2001): Der } \\
\text { ökonomische Wert der } \\
\text { Wälder in Deutschland } \\
\text { für die Naherholung: Eine } \\
\text { "Benefit Function Trans- } \\
\text { fer" Schätzung Zeitschrift } \\
\text { für Umweltpolitik und } \\
\text { Umweltrecht } 24 \text { (3), S. } \\
\text { 417-442. Year: 1995. }\end{array}$ & $\begin{array}{l}\text { Number of visits: 1,700,000 (data in visits/year of } \\
\text { population over } 14 \text { years, estimated from the } \\
\text { number of forest visitors and the average visit } \\
\text { frequency.) } \\
\text { Visitors in forests: } 44,422 \text { (data for 1995; German } \\
\text { forest visitors - age } 14 \text { years and older, excluding } \\
\text { holiday makers, excluding people with less than } 1 \\
\text { forest visit/year) } \\
\text { Compiled from 10,740,000 ha. } \\
95 \% \text { Confidence interval: } 42,622-46,168 . \\
\text { Data source: ELSASSER, P. (2001): Der ökonomi- } \\
\text { sche Wert der Wälder in Deutschland für die } \\
\text { Naherholung: Eine "Benefit Function Transfer" } \\
\text { Schätzung Zeitschrift für Umweltpolitik und } \\
\text { Umweltrecht } 24 \text { (3), S. } 417-442 \\
\text { Assumption: } 200,000 \text { ha or } 2 \% \text { of the forest area is } \\
\text { restricted for military purpose. } \\
\text { (1,700 million visits/year; } \\
20.6 \text { visits/person/year; } \\
\text { Estimated from the number of forest visitors and } \\
\text { average visit frequency.) }\end{array}$ & $\begin{array}{l}\text { OK. } \\
\text { Figure cited in SOEF } 2011 \text { appears to } \\
\text { be rounded down from Elsasser's } \\
\text { (2001) estimate of 1,700 million. }\end{array}$ \\
\hline
\end{tabular}




\begin{tabular}{|c|c|c|c|c|c|c|c|c|}
\hline \multirow[t]{2}{*}{ Country } & \multicolumn{3}{|c|}{$\begin{array}{l}\text { Annual number of visits } \\
\text { (million) }\end{array}$} & \multirow{2}{*}{$\begin{array}{l}\text { Comments related } \\
\text { to data, definitions, } \\
\text { etc. (SOEF 2011) }\end{array}$} & \multirow[t]{2}{*}{$\begin{array}{l}\text { Comments on trend(s) } \\
\text { (SOEF 2011) }\end{array}$} & \multirow[t]{2}{*}{$\begin{array}{l}\text { Data sources } \\
\text { (SOEF 2011) }\end{array}$} & \multirow[t]{2}{*}{$\begin{array}{l}\text { Comments (SOEF 2007)(and Data } \\
\text { (Table 32, p100)) }\end{array}$} & \multirow[t]{2}{*}{ Analysis } \\
\hline & 2005 & 2000 & 1990 & & & & & \\
\hline Ireland & 18 & 8.5 & n.a. & & $\begin{array}{l}\text { No data available for } \\
\text { 1990. Clinch (1999) } \\
\text { estimated that there } \\
\text { were } 8.5 \text { million } \\
\text { visitors. }\end{array}$ & $\begin{array}{l}\text { Fitzpatrick and associates } \\
\text { report. High quality. Year: } \\
2005 . \\
\text { Economics of Irish forest- } \\
\text { ry. Pater Clinch, 1999. High } \\
\text { quality. Year: 2000. }\end{array}$ & & ОК. \\
\hline Italy & n.a. & 168 & n.a. & $\begin{array}{l}\text { Only information } \\
\text { found refers to the } \\
\text { publication cited in } \\
\text { data sources }\end{array}$ & & $\begin{array}{l}\text { Croitoruo, Gatto, Merlo } \\
\text { and Pairo in the volume } \\
\text { edited by Merlo and } \\
\text { Croitoru "Valuing Medi- } \\
\text { terranean Forests - } \\
\text { Towards Total Economic } \\
\text { Value," 2005, CABI } \\
\text { Publishing. Medium } \\
\text { Quality. Year: 2000. }\end{array}$ & $\begin{array}{l}\text { Number of visits } 100,000-200,000 \text { (1,000 visits) } \\
\text { and visitors in forests: } 68,000-168,000 \text { ( } 1,000 \\
\text { persons), compiled from } 10,479,000 \text { ha. } \\
\text { Number of visits in the forests have been estimat- } \\
\text { ed for all Italy by Croitoruo, Gatto, Merlo and Pairo } \\
\text { in the volume edited by Merlo and Croitoru } \\
\text { "Valuing Mediterranean Forests - Towards Total } \\
\text { Economic Value," 2005, CABI Publishing } \\
\text { Number of visits in rural areas estimated with a } \\
\text { subjective approach by the Ministry of Agricultural } \\
\text { and Forest Policies. } \\
\text { (150.0 million visits/year; } \\
2.6 \text { visits/person/year; } \\
\text { Average of } 100-200 \text { million visits per year.) }\end{array}$ & $\begin{array}{l}\text { The estimate of } 168 \text { given for yr2000 } \\
\text { in SOEF } 2011 \text { could perhaps have } \\
\text { been used for } 2005 \text { as well (assuming } \\
\text { no evidence to suggest significant } \\
\text { changes) }\end{array}$ \\
\hline Lithuania & 135 & п.а. & n.a. & & & $\begin{array}{l}\text { Lietuvos gyventoju } \\
\text { sociologines apklausos } \\
\text { svarbiausiais mišku ükio } \\
\text { klausimais bei respon- } \\
\text { denty nuomonès analizės } \\
\text { atlikimas (Sociologilal } \\
\text { survey of residents of } \\
\text { Lithuania regarding main } \\
\text { issues of forestry and } \\
\text { analysis of results). } \\
\text { Kaunas, 2006, } 253 \mathrm{~m} \text {. } \\
\text { (manuscript). High } \\
\text { quality. Year: 2006. MR. }\end{array}$ & & OK. \\
\hline
\end{tabular}




\begin{tabular}{|c|c|c|c|c|c|c|c|c|}
\hline \multirow[t]{2}{*}{ Country } & \multicolumn{3}{|c|}{$\begin{array}{l}\text { Annual number of visits } \\
\text { (million) }\end{array}$} & \multirow{2}{*}{$\begin{array}{l}\text { Comments related } \\
\text { to data, definitions, } \\
\text { etc. (SOEF 2011) }\end{array}$} & \multirow[t]{2}{*}{$\begin{array}{l}\text { Comments on trend(s) } \\
\text { (SOEF 2011) }\end{array}$} & \multirow[t]{2}{*}{$\begin{array}{l}\text { Data sources } \\
\text { (SOEF 2011) }\end{array}$} & \multirow[t]{2}{*}{$\begin{array}{l}\text { Comments (SOEF 2007)(and Data } \\
\text { (Table 32, p100)) }\end{array}$} & \multirow[t]{2}{*}{ Analysis } \\
\hline & 2005 & 2000 & 1990 & & & & & \\
\hline $\begin{array}{l}\text { Nether- } \\
\text { lands }\end{array}$ & 270 & 270 & 270 & $\begin{array}{l}\text { A survey performed } \\
\text { by TNS-NIPO con- } \\
\text { cluded that on } \\
\text { average } 750,000 \\
\text { people visit the } \\
\text { Dutch forests each } \\
\text { day. }\end{array}$ & $\begin{array}{l}\text { No new studies have } \\
\text { been performed since } \\
1997 \text { and no infor- } \\
\text { mation is available } \\
\text { about a possible } \\
\text { increase or decrease in } \\
\text { the number of visitors. } \\
\text { For this reason the } \\
\text { number of visitors is } \\
\text { kept stable in this } \\
\text { table. }\end{array}$ & $\begin{array}{l}\text { TNS-NIPO, 1997, Dagelijks } \\
750,000 \text { bezoeken aan de } \\
\text { bossen, ProBos vraagt } \\
\text { financiering voor } \\
\text { maatschappelijke func- } \\
\text { ties, persbericht, } \\
\text { http://www.tns- } \\
\text { nipo.com/pages/nieuws- } \\
\text { pers-vnipo.asp?file= } \\
\text { persvannipolbos.htm. } \\
\text { High quality. Year: 1997. }\end{array}$ & $\begin{array}{l}\text { Number of visits } 270,000 \text { ( } 1,000 \text { visits) and visitors } \\
\text { in forests: } \mathrm{n} . \mathrm{a} .(1,000 \text { persons), compiled from } \\
360,000 \text { ha. } \\
\text { ( } 270 \text { million visits/year; } \\
16.6 \text { visits/person/year; } \\
\text { Compiled from } 360,000 \text { ha.) }\end{array}$ & OK. \\
\hline Norway & 140 & 108 & 34 & $\begin{array}{l}\text { Has been calculated } \\
\text { from population } \\
\text { figures and frequen- } \\
\text { cies and percentages } \\
\text { obtained from the } \\
\text { quoted studies. }\end{array}$ & & $\begin{array}{l}\text { Vågane, L (2002). } \\
\text { Samordnet levekårsun- } \\
\text { dersøkelse } 2001 \text { - } \\
\text { tverrsnittsundersøkelsen: } \\
\text { dokumentasjonsrapport. } \\
\text { Oslo: Statistisk Sentral- } \\
\text { byrå. Medium quality. } \\
\text { Year: } 2001 . \\
\text { Houghen, H C. (2005). } \\
\text { Samordnet levekårsun- } \\
\text { dersøkelse } 2004 \text { - } \\
\text { tverrsnittsundersøkelsen: } \\
\text { dokumentasjonsrapport. } \\
\text { Oslo: Statistisk Sentral- } \\
\text { byrå. Medium quality. } \\
\text { Year: } 2004 .\end{array}$ & & OK. \\
\hline $\begin{array}{l}\text { Russian } \\
\text { Federa- } \\
\text { tion }\end{array}$ & 1 & 0.6 & n.a. & & & & & $\begin{array}{l}\text { Very low figure presumably refers to a } \\
\text { small area. }\end{array}$ \\
\hline
\end{tabular}




\begin{tabular}{|c|c|c|c|c|c|c|c|c|}
\hline \multirow[t]{2}{*}{ Country } & \multicolumn{3}{|c|}{$\begin{array}{l}\text { Annual number of visits } \\
\text { (million) }\end{array}$} & \multirow{2}{*}{$\begin{array}{l}\text { Comments related } \\
\text { to data, definitions, } \\
\text { etc. (SOEF 2011) }\end{array}$} & \multirow[t]{2}{*}{$\begin{array}{l}\text { Comments on trend(s) } \\
\text { (SOEF 2011) }\end{array}$} & \multirow[t]{2}{*}{$\begin{array}{l}\text { Data sources } \\
\text { (SOEF 2011) }\end{array}$} & \multirow[t]{2}{*}{$\begin{array}{l}\text { Comments (SOEF 2007)(and Data } \\
\text { (Table 32, p100)) }\end{array}$} & \multirow[t]{2}{*}{ Analysis } \\
\hline & 2005 & 2000 & 1990 & & & & & \\
\hline Sweden & n.a. & n.a. & n.a. & & & & $\begin{array}{l}\text { Survey compiled by Cairos Future } 2005 \text { indicates } \\
\text { that } 3 / 4 \text { of all Swedes visit the forest every week. A } \\
\text { survey complied by the National Institute of } \\
\text { Statistics (SCB) } 1987-1993 \text { indicates: } 79 \% \text { of all } \\
\text { Swedes visit forests at least once a year, } 57 \% \text { at } \\
\text { least } 5 \text { visits a year, } 31 \% \text { at least } 20 \text { visits a year } \\
\text { and } 7 \% \text { at least } 60 \text { times a year. Women visit } \\
\text { forests more often than men. This survey covers a } \\
\text { lot of socioeconomic, economic and demographic } \\
\text { factors like profession, education ethnical back- } \\
\text { ground, age, place of residence etc. } \\
\text { Urban and periurban forests mainly in public } \\
\text { ownership cover around } 300,000 \text { ha or approx } 1 \% \\
\text { of the forests. Around } 60 \% \text { or even more of the } \\
\text { forest recreation takes place in these urban } \\
\text { woodlands. [...] The forest land in proximity to } \\
\text { urban areas is not changing rapidly according to } \\
\text { earlier inventories. } \\
\text { (339 million visits per year; } \\
37.5 \text { visits/person/year; } \\
75 \% \text { of the population visit once a week.) }\end{array}$ & $\begin{array}{l}\text { It is not clear why the estimate } \\
\text { provided in SOEF 2007, Table } 32 \text {, of } \\
339 \text { million visits hasn't been includ- } \\
\text { ed. Possibly it is considered out of } \\
\text { date, if based on data from the } \\
\text { National Institute of Statistics survey } \\
\text { 1987-1993. }\end{array}$ \\
\hline $\begin{array}{l}\text { Switzer- } \\
\text { land }\end{array}$ & 540 & n.a. & n.a. & $\begin{array}{l}\text { The number of visits } \\
\text { is derived from } \\
\text { SAEFL, 2000: The } \\
\text { social demands on } \\
\text { Swiss Forests }\end{array}$ & & $\begin{array}{l}\text { SAEFL, 2000: The social } \\
\text { demands on Swiss } \\
\text { Forests. (quality not } \\
\text { recorded) Year: } 1997 .\end{array}$ & $\begin{array}{l}\text { Number of visits } 540,000 \text { ( } 1,000 \text { visits) and visitors } \\
\text { in forests: } 7,104 \text { (1,000 persons), compiled from } \\
450 \text { visits/ha. } \\
\text { The number of visits is derived from SAEFL, } 2000 \text { : } \\
\text { The social demands on Swiss Forests. } \\
\text { Number of visitors in the forest: } 96 \% \text { of the total } \\
\text { Swiss population (7,400,000 people). } \\
\text { (339.0 million visits/year; } \\
24.8 \text { visits/person/year) }\end{array}$ & OK. \\
\hline
\end{tabular}

Limited to reserves and national parks. 


\begin{tabular}{|c|c|c|c|c|c|c|c|c|}
\hline \multirow[t]{2}{*}{ Country } & \multicolumn{3}{|c|}{$\begin{array}{l}\text { Annual number of visits } \\
\text { (million) }\end{array}$} & \multirow{2}{*}{$\begin{array}{l}\text { Comments related } \\
\text { to data, definitions, } \\
\text { etc. (SOEF 2011) }\end{array}$} & \multirow[t]{2}{*}{$\begin{array}{l}\text { Comments on trend(s) } \\
\text { (SOEF 2011) }\end{array}$} & \multirow[t]{2}{*}{$\begin{array}{l}\text { Data sources } \\
\text { (SOEF 2011) }\end{array}$} & \multirow[t]{2}{*}{$\begin{array}{l}\text { Comments (SOEF 2007)(and Data } \\
\text { (Table 32, p100)) }\end{array}$} & \multirow[t]{2}{*}{ Analysis } \\
\hline & 2005 & 2000 & 1990 & & & & & \\
\hline $\begin{array}{l}\text { United } \\
\text { Kingdom }\end{array}$ & 350 & 350 & 350 & $\begin{array}{l}\text { Most household } \\
\text { surveys since } 1990 \\
\text { have indicated } \\
\text { annual totals of over } \\
300 \text { million day visits } \\
\text { to woodland from } \\
\text { home by adults. This } \\
\text { excludes visits made } \\
\text { while staying away } \\
\text { from home, visits by } \\
\text { overseas tourists, } \\
\text { visits by children } \\
\text { (under } 16) \text { and visits } \\
\text { not considered to be } \\
\text { leisure (e.g. some } \\
\text { routine dog walking). } \\
\text { These household } \\
\text { surveys also indicate } \\
\text { that around } 40 \% \text { of } \\
\text { UK adults have made } \\
\text { at least one such } \\
\text { visit in the previous } \\
\text { year. An alternative } \\
\text { source (Public } \\
\text { Opinion of Forestry } \\
\text { survey) indicates } \\
\text { that about two- } \\
\text { thirds of UK adults } \\
\text { have visited wood- } \\
\text { land in the last few } \\
\text { years, which corrob- } \\
\text { orates the view that } \\
\text { the household } \\
\text { surveys exclude } \\
\text { some routine visits. }\end{array}$ & $\begin{array}{l}\text { Changing methodolo- } \\
\text { gies of household } \\
\text { surveys make it } \\
\text { difficult to obtain } \\
\text { reliable time trends. } \\
\text { Where the Public } \\
\text { Opinion of Forestry } \\
\text { surveys used the same } \\
\text { omnibus surveys over } \\
\text { a long period they did } \\
\text { not show much varia- } \\
\text { tion over time in the } \\
\text { level of visiting, so no } \\
\text { change is reported. } \\
\text { Most forest recreation } \\
\text { is at sites with good } \\
\text { recreation infrastruc- } \\
\text { ture, so the increase in } \\
\text { total area with access } \\
\text { arising from the 2000 } \\
\text { and } 2003 \text { Acts would } \\
\text { not be expected to } \\
\text { have a major impact } \\
\text { on the total number of } \\
\text { visits. The increased } \\
\text { number of recreation } \\
\text { sites and community } \\
\text { woodlands would have } \\
\text { been expected to make } \\
\text { a positive impact, but } \\
\text { there will have been } \\
\text { some displacement } \\
\text { (visiting the new sites } \\
\text { instead of existing } \\
\text { sites) and continuing } \\
\text { enhancement is } \\
\text { needed to counter } \\
\text { other the growing } \\
\text { range of non-forest } \\
\text { attractions and home- } \\
\text { based recreation. }\end{array}$ & $\begin{array}{l}\text { Household recreation } \\
\text { surveys. Medium quality. } \\
\text { Years: all. } \\
\text { UK/GB Day Visits Surveys } \\
\text { from } 1994 \text { to } 2002 / 03 \text {, } \\
\text { separate country surveys } \\
\text { in later years, summa- } \\
\text { rised in Forestry Statistics } \\
2009 \text { Table 6.1. Medium } \\
\text { quality. Years: all. } \\
\text { Public Opinion of Forestry } \\
\text { surveys. Medium quality. } \\
\text { Years: all. }\end{array}$ & $\begin{array}{l}\text { Number of visits (1,000 visits) and visitors in } \\
\text { forests: (1,000 persons), compiled from ha. See } \\
\text { below } \\
\text { a) Household surveys since } 1990 \text { have indicated } \\
\text { annual totals of around } 300 \text { million day visits to } \\
\text { woodland from home by adults. This excludes } \\
\text { visits made while staying away from home, visits } \\
\text { by overseas tourists, visits by children (under } 16 \text { ) } \\
\text { and visits not considered to be leisure (e.g. some } \\
\text { routine dog walking). } \\
\text { b) These household surveys also indicate that } \\
\text { around } 40 \% \text { of UK adults have made at least one } \\
\text { such visit in the previous year. An alternative } \\
\text { source (Public Opinion of Forestry survey) indi- } \\
\text { cates that about two-thirds of UK adults have } \\
\text { visited woodland in the last few years. } \\
\text { (300.0 million visits per year; } \\
5.0 \text { visits/person/year; } \\
300 \text { million day visits by adults to woodland from } \\
\text { home, excluding visits made while staying away } \\
\text { from home; visits by overseas tourists; visits by } \\
\text { children (under } 16 \text { ) and visits not considered } \\
\text { leisure (e.g. routine dog walking).) }\end{array}$ & OK. \\
\hline
\end{tabular}


Nordic Council of Ministers

Ved Stranden 18

DK-1061 Copenhagen K

www.norden.org

\section{Social Indicators in the Forest Sector in Northern Europe}

Forest related social values such as recreation values are growing in importance in North European countries. Our urbanized societies need social services from forests and other nature areas. One of the key ecosystem services is the recreation environment provided by forests. Possibilities to enhance commercial recreational use of forests has been recognized, particularly among private forest owners, who have new opportunities for new types of forest-related entrepreneurship. This report provides a review of social indicators in forestry, particularly concerning nature-based recreation and tourism in North European countries. The common interest among scientists and other experts was to discuss how to develop social indicators and to monitor changes to social benefits in forestry and forest use. In all countries, there is a challenge to develop monitoring systems to produce inventory data for statistics that are required in a way that provid es comparable social indicators. It is timely to enhance standardization and harmonization of social indicators for monitoring and management of sustainable forestry and forest use, and for sustainable nature-based recreation and tourism. 